\title{
حرية الإنسان في السياسة الشرعية
}

$$
\begin{aligned}
& \text { * أيمن مصطفى حسين الدباغ } \\
& \text { الملخص } \\
& \text { يهدف هذا البحث إلى بيان التصور الإسلامي للحرية، ومكانتها في السياسة الشرعية، والقواعد التي تحكمها في } \\
& \text { هذا المحال .وقد عُني بالتأصيل الكلي أكثر من عنايته بالتفاصيل .يتضمن البحث ثلاثة أقسام؛ تناول أولها المفهوم }
\end{aligned}
$$

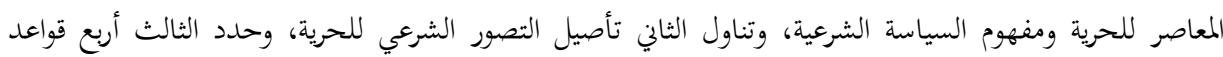

$$
\begin{aligned}
& \text { للحرية في السياسة الشرعية .وخلص البحث إلى أنّ الحرية الإنسانية تتربَّع على قمّة هرم المقاصد الإسلامية ومقاصد } \\
& \text { السياسة الشرعية، ويوصي بضرورة اتباع منهج التأصيل في السياسة الشرعية، والعمل على تطوير علمٍٍ لهذه السياسة. } \\
& \text { الكلمات المفتاحية :الحرية، السياسة الشرعية، التأصيل الشرعي، التصور الإسلامي. }
\end{aligned}
$$

\section{Human Freedom in Islamic Policy}

\section{Abstract}

This study aims to illustrate the Islamic perception of freedom, its importance in Islamic policy, and the rules governing this subject, with an emphasis on the grounding theory $\left(T a^{\prime}\right.$ sil $)$ rather than the details. The study is divided into three sections: The first discusses the contemporary concepts of freedom and Islamic policy (Al-Siyasa alShar'iyya). The second aims to extract and ground the foundations of an Islamic conception of freedom. The third sets four rules of freedom in Islamic policy.

The study concludes that human freedom is positioned at the pinnacle of the Islamic intents (Maqasid) in general, and the intents of legal policy in particular. The study suggests the necessity of applying the methodology of Ta'sil in Islamic legal policy and working to develop the science of Islamic policy.

Keywords: Freedom, Legal Islamic Policy, Ta'sil, Islamic Worldview.

"دكتوراه في الفقـه الإسـامي وأصوله، الجامعة الأردنية، r . . rم، أستاذ مسـاعد في كلية الشريعة، جامعة النجاح

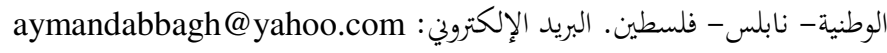

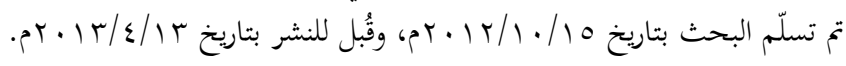




\section{مقدمة:}

يتناول البحث قضية مهمة اكتسبت شأناً خاصّاً في خضم تطورات الربيع العربي، وما بنم عنه من صعود تيارات إسلامية إلى سدّة الحكم. وقد رافق ذلك توارد العديد من الأسئلة المتعلقة بمدى إمكانية الجمعع بين الديني والدنيوي، أو المزاوجة بين الدولة الدينية إلينية، والمحافظة على حقـوق الإنسـان وحرياتـه العامـة فيها. وفي هـذا السياق، ظهرت مفـاهيم جديدة مثل مفهوم "الدولة الإسلامية المدنية"، وهو مفهوم غامض، لمُ يُبذل جهد كافٍ

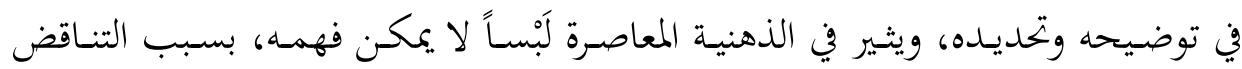
التاريخي المستحكم عندها بين صفتي الدينية والمدنية. إنّ هذا المفهوم وما يماثله من مفاهيم وتعبيرات تُقال على عجل، للدفاع عن الذات

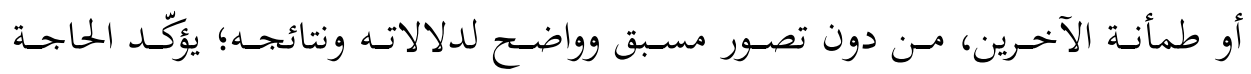

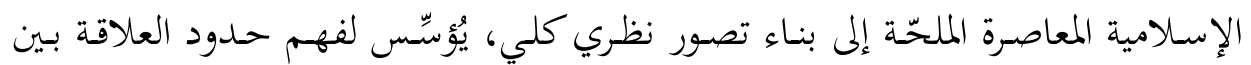
الديني والدنيوي في دولة ذات مشروع إسلامي، ويوائم بين مقصد الدين ومقصد حفظ

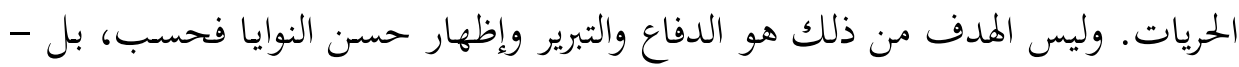
وهو الأهم- بناء وعينا الذاتي، ورؤيتنا الخاصة، وتحديد أهدافنا. يهـدف هذا البحثث إلى بناء تصور شرعي شامل لموضوع الحرية، وإبراز مركزيته في

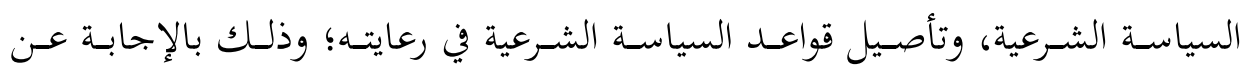

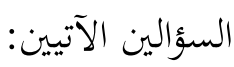

- ما التصور الإسلامي لحرية الإنسان؟ ما خصائصه؟ - - ما القواعد التي تحكم موضوع الحرية في السياسة الشرعية؟

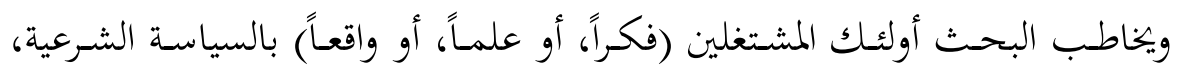
المؤمنين بضرورة إقامتها، ولا يُعنى بمحاطبة مَنْ أنكر إمكانية الجممع بين الديني والدنيوي،

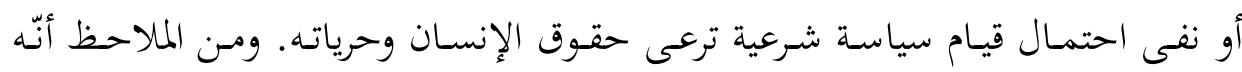

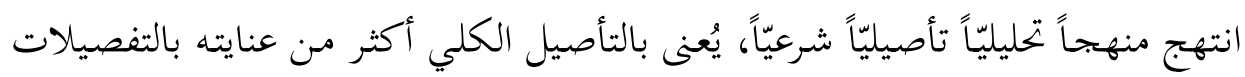


الجزئيسة، مـع تجنُّب الخـوض في قضـايا تفصيلية، مسن مثلـ: أنواع الحريـات، والإجـراءات

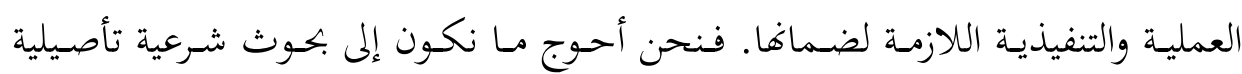

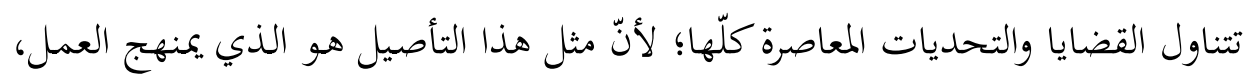
ويؤسس لرؤية واضحة للذات، ويعصمم مـن التناقض والضياع في التفاصيل، ويحمي مـن الاستلاب الشعوري أو غير الشعوري لتصورات الآخرين ورؤاهم. وعلى الرغم من تعدُّد الكتابات الإسلامية المعاصرة في موضوع الحرية، إلاّ أنّ أكثرها

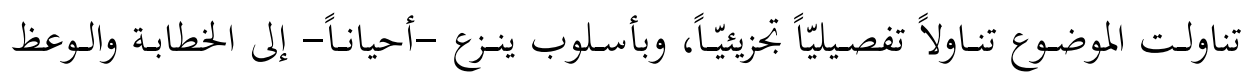

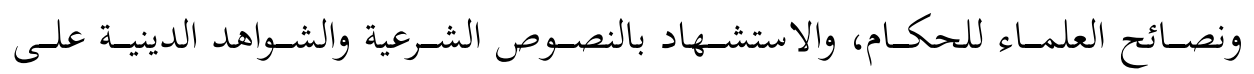

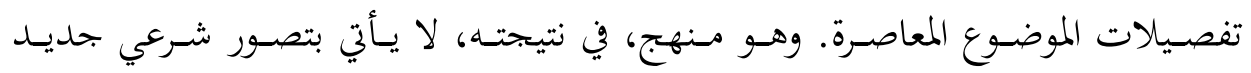

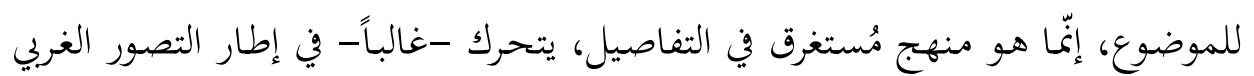

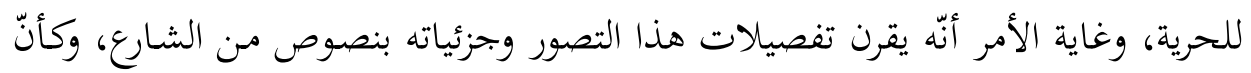
مثل هذا الاستشهاد الشكلي يجعل التصور شرعيّاً إسلاميّاً. قُسِّم البحث إلى ثلاثة محاور رئيسة هي: مفهوم "حرية الإنسان"، ومفهوم "السياسة الشرعية". والتصور الإسلامي لحرية الإنسان. وقواعد الإلزام في السياسة الشرعية.

أوّلاً: مفهوم "حرية الإنسان"، ومفهوم "السياسة الشرعية"

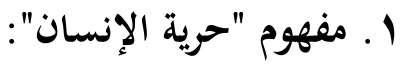

لفظة "الحرية" هي من أكثر الألفاظ تداولاً، خاصة في العصور الحديثة؛ نظرًا لما تُمثِّه

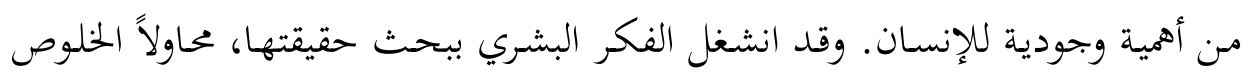
إلى تعريف لهـا، فلم تزدد بـذلك إلاّ غموضًا؛ ذلك أنّ الحريـة ليست حقيقـةً موضـوعيةً

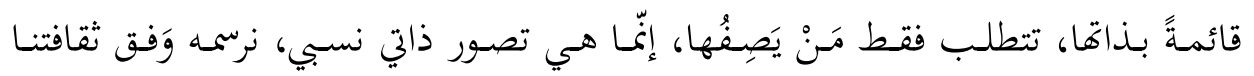

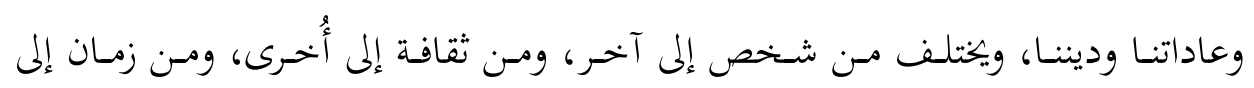

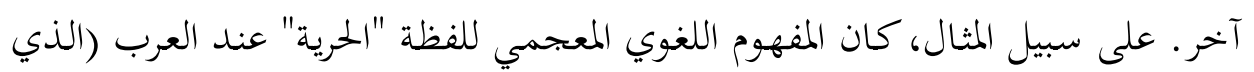




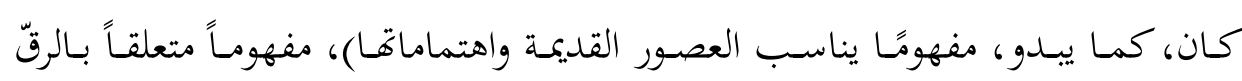

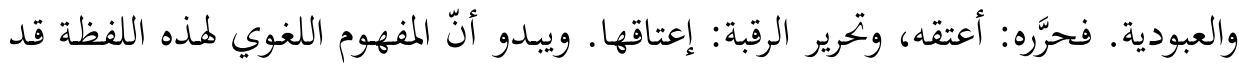

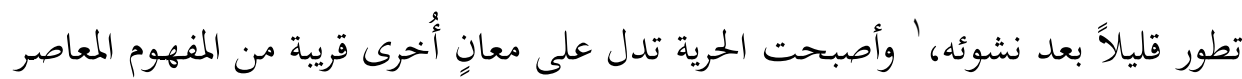

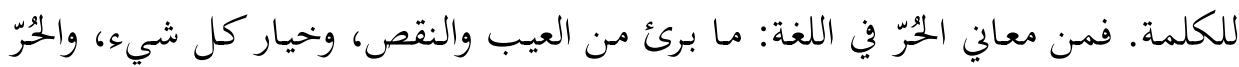

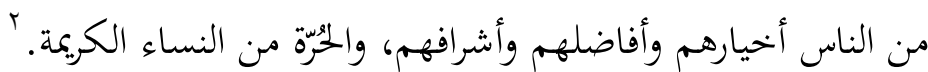

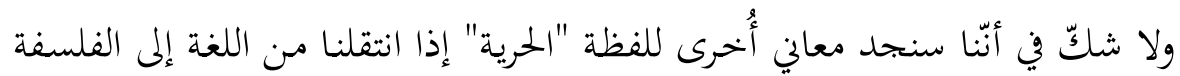

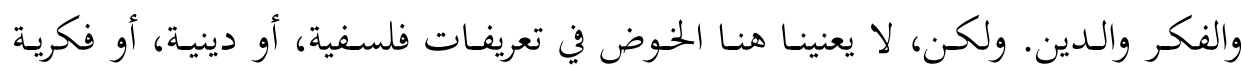
لمذه المفردة. فالبحث في معنى الحرية، كما يقول الغنوشي، ما لبث أن غادر الميتافيزيقا

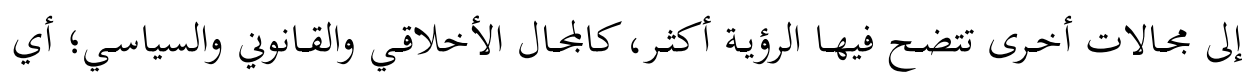

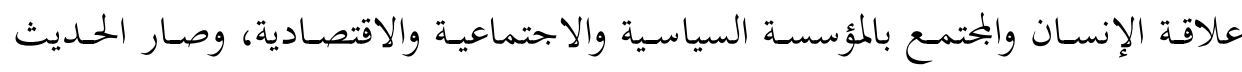

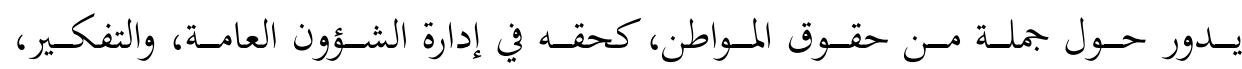

$$
\text { والاعتقاد.... }
$$

يمكن تعريف مفهوم "الحرية" المعاصر، الذي نقصده في هذا البحث، بأنّه: الحدود

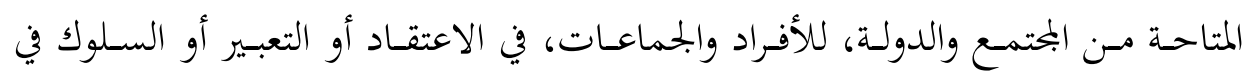
مجالات الحياة المتعددة؛ الدينية، والفكرية، والسياسية، وغيرها.

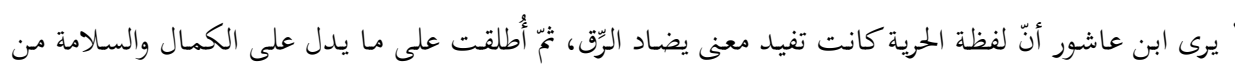

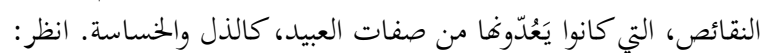

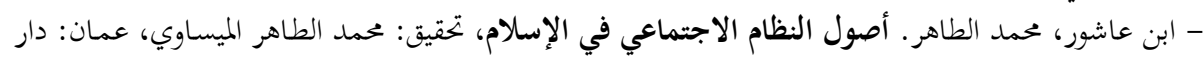

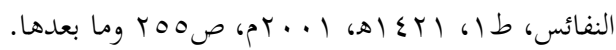

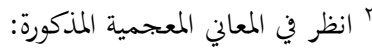
- ابن فارس، أبو الحسين أممد. معجم مقاييس اللغة، تحقيق: عبد السلام هارون، بيروت: دار الجيل، طجا،

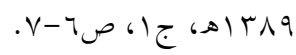
- الجوهري، إسماعيل بن حماد. الصحاح، المسمى تاج اللغة وصحاح العربية، تحقيق: أممد عبد الغفور عطار،

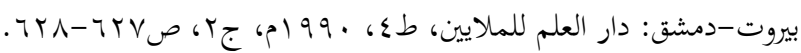

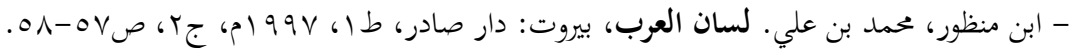

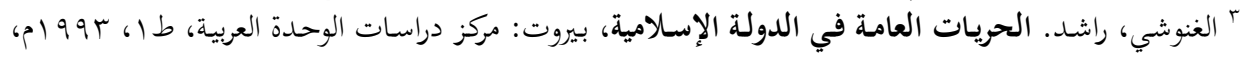

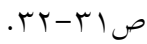




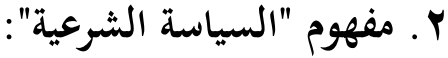

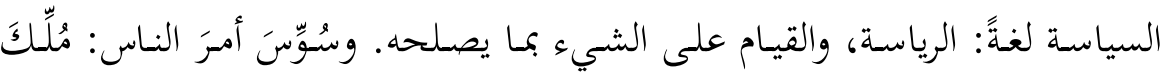

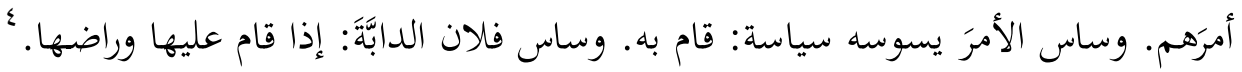

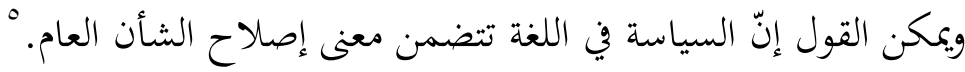
وقد وردت لفظة "السياسة" في كتب الفقهاء بمعنى الحكم الذي تقتضيه المصلحة العامة، وكثر ذلك على لساغم، خاصة في باب العقوبات، مثل قول الشربيني: "لو أمر

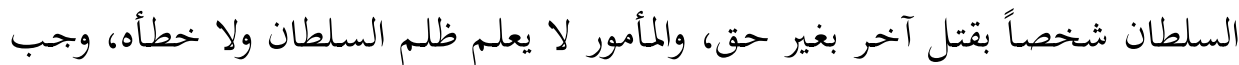
القَوَدُ أو الدية والكفارة على السلطان، ولا شيء على المأمور، لأنه آلته، ولا بدّ منه في

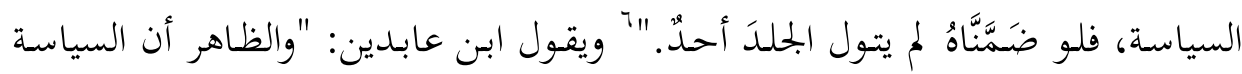

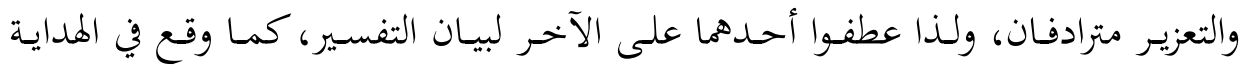

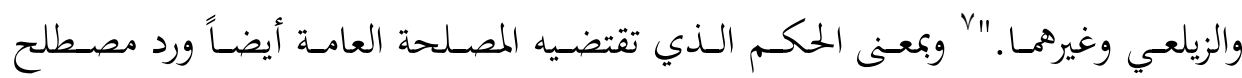

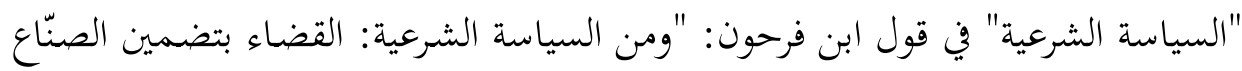
$\Lambda_{\prime \prime}$

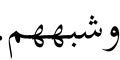

"الفيروز آبادي، عمدد بن يعقوب. القاموس المحيط، بيروت: دار الفكر، 10 إهـ/9901م) ص99 ع. انظر أيضاً:

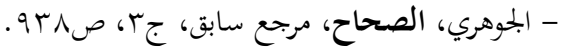

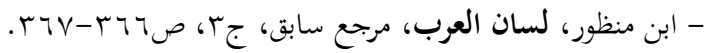

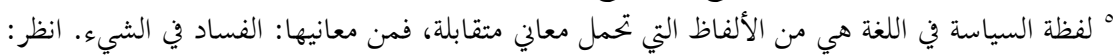

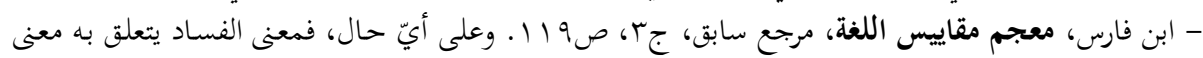
القيام على الشيء بما يصلحه. 7 الشربيني، كمد بن أمدا، مغني المحتاج إلى معرفة معاني ألفاظ المنهاج، بيروت: دار الكتب العلمية، طه،

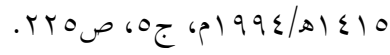

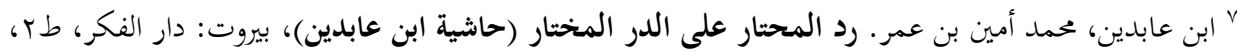

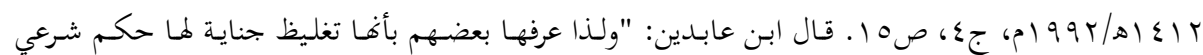

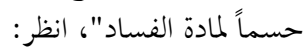

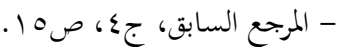

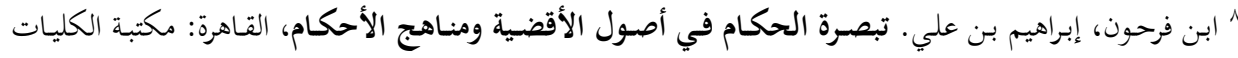

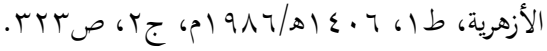




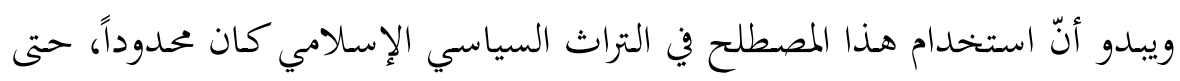

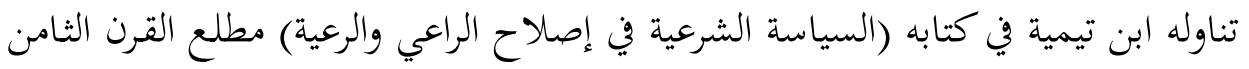

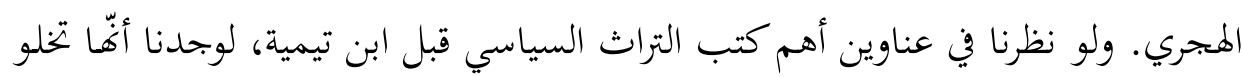

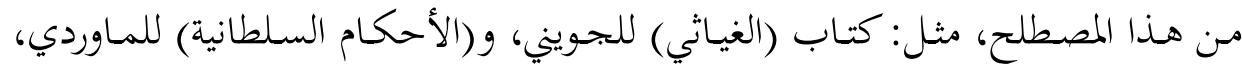

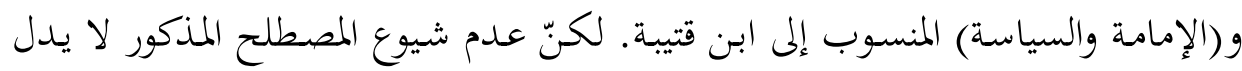

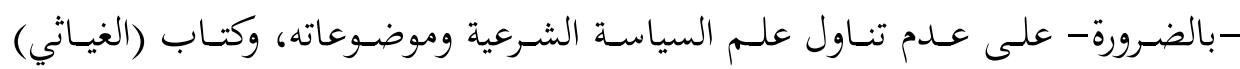

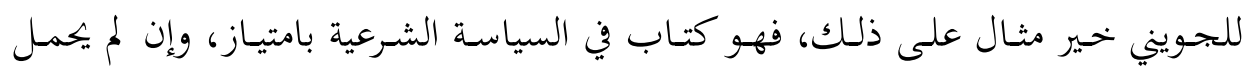
عنوان (السياسة الشرعية). وإذا كانت السياسة لغةً تتضمن معنى إصلاح الشأن العام، فإنّ السياسة الشرعية

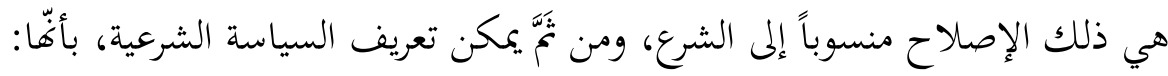

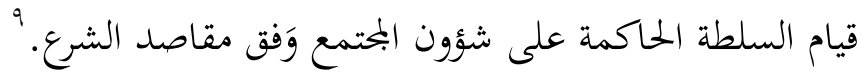

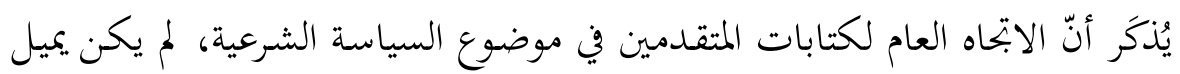

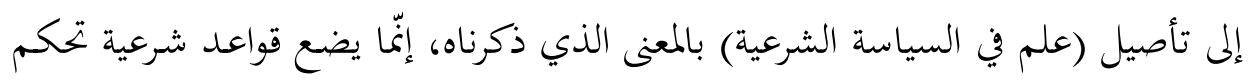

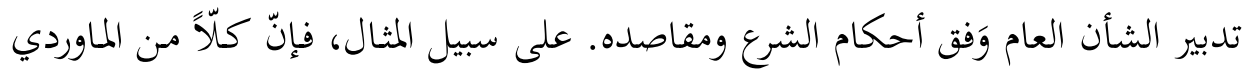

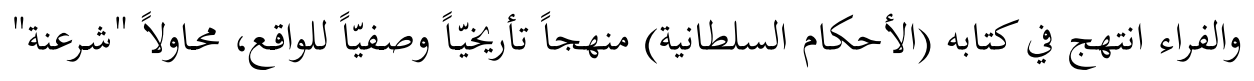

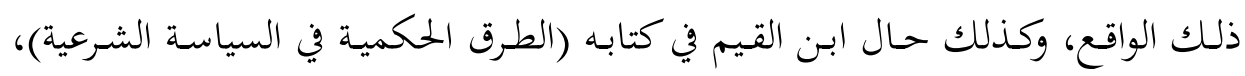
الذي يكاد يكون أشبه بكتاب في الأحكام القضائية وأماراتما.

9 استخلصنا هذا التعريف للسياسة الشرعية، مع بعض التحوير، من المحاضرات القيمة التي ألقاها علينا أستاذنا الدكتور

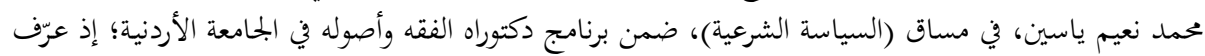

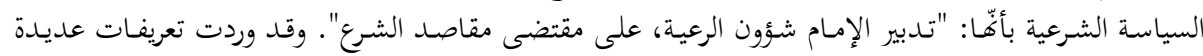

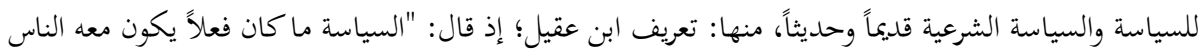

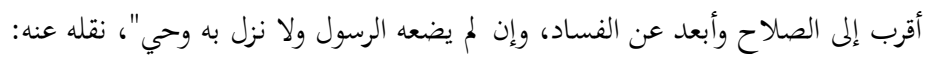
- ابن قيم الجوزية، محمد بن أبي بكر . الطرق الحكمية في السياسة الشرعية، تحقيق: عصام الحرستاني، تخريج:

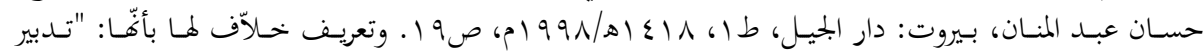

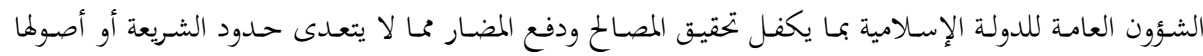

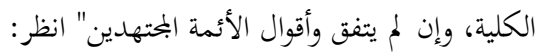

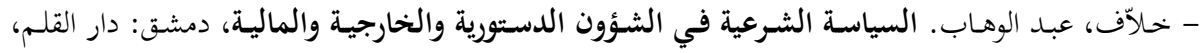
r. 
وفي المقابل، فقـد انصبّ اهتمام كتابـات قديمة أُخرى على الشـأن العام، بالحـديث

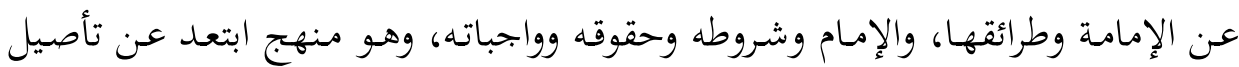

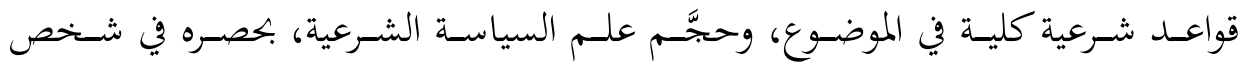

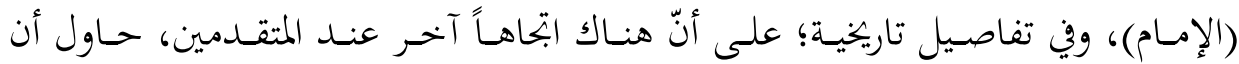

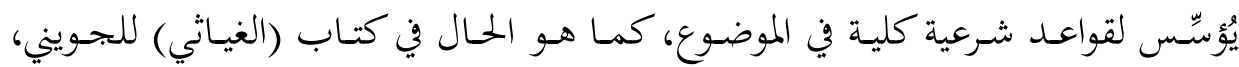
وكتاب (السياسة الشرعية) لابن تيمية.

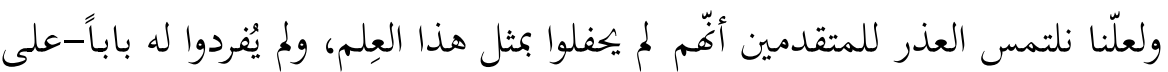

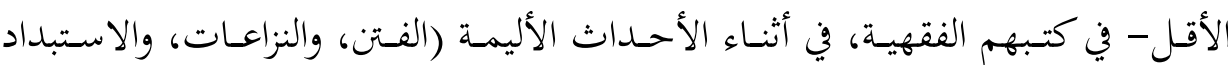

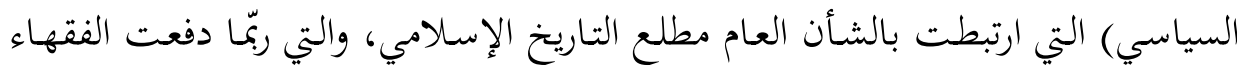

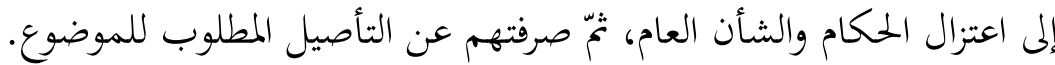

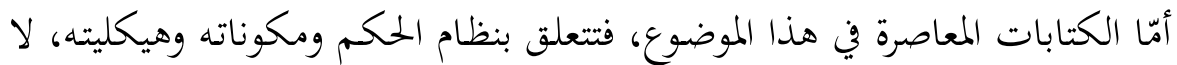
بتأصيل قواعد شرعية تحكم السلوك العام. ومن الملاحظ أنّ الكتابات المعاصرة التي جاء

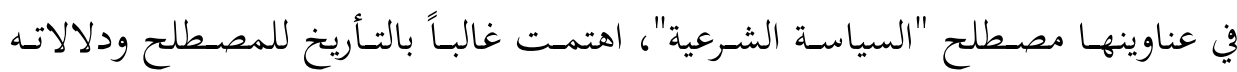

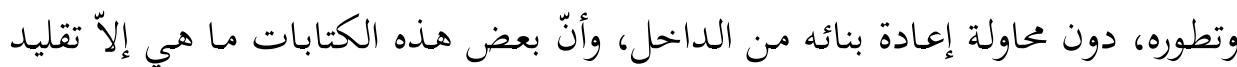
لمنهج المتقدمين في السياسة الشرعية؛ شكالاً، ومضموناً. وقـد حاولنـا في هـذه العُجالـة أن نعيـد الكتابـة في السياسـة الشـرعية بـنهج التأصسيل

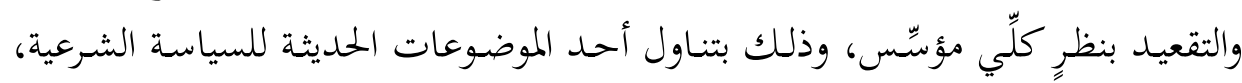
وهو حرية الإنسان.

\section{ثانيًا: التصور الإسلامي لحرية الإنسان}

\section{I ـ مظاهر التكريم المادية للإنسان:}

لقد احتُفِي بالإنسان حفاوة لم يَخًَ بها أيّ مخلوق آخر، واستُقبِل بمظاهر تكريم إلهي

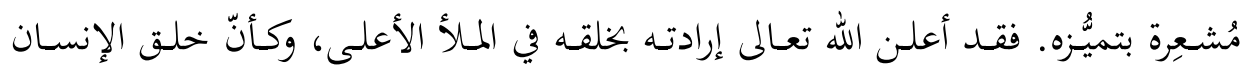

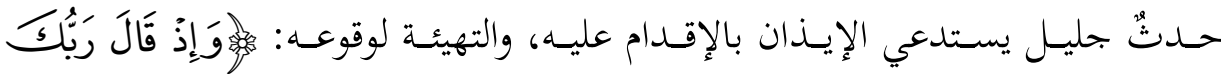




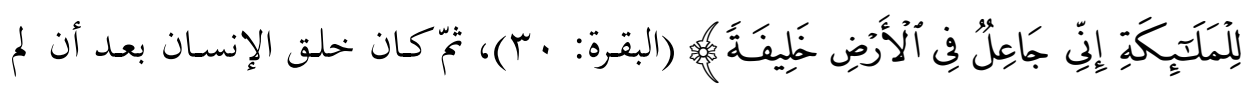

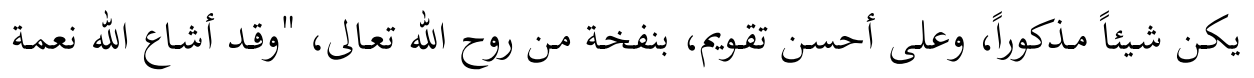

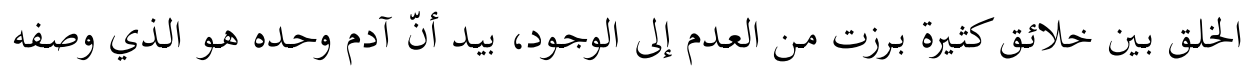

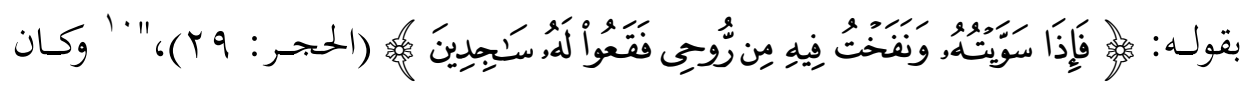

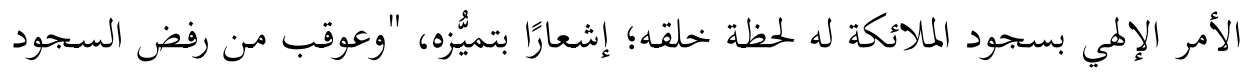

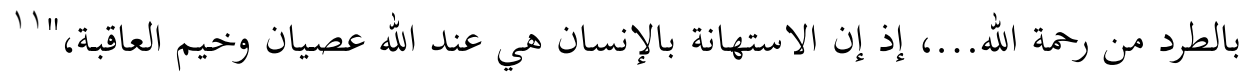

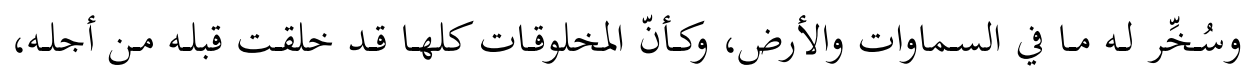

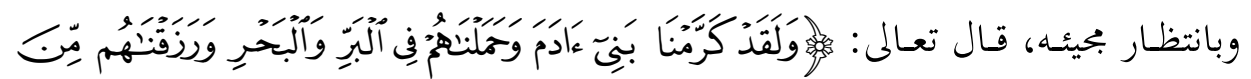

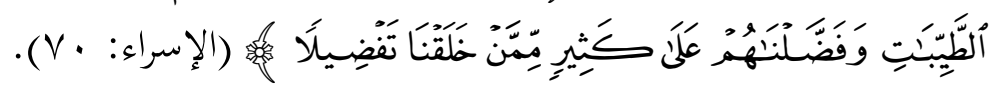

\section{r. ب تميُّز الإنسان بحرية الاختيار:}

يتميَّز الإنسان على سائر المخلوقات بمزايا خَلقية عديدة، فهو أحسن المخلوقات

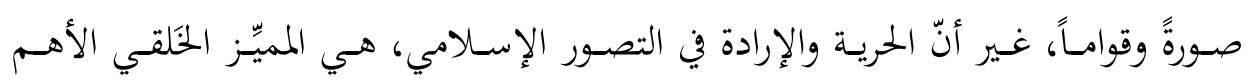

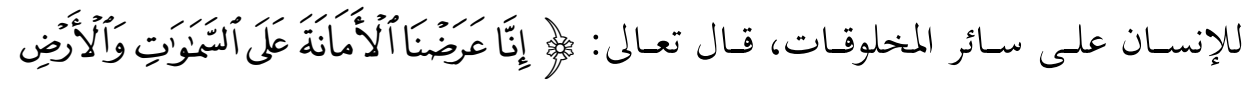

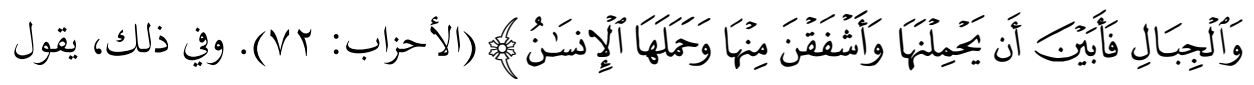

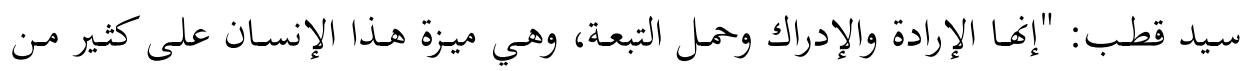

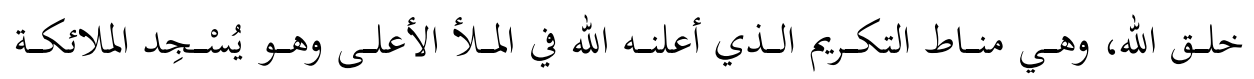
لآدم." آل

إنّ الحرية في التصور الإسلامي صفة لصيقة بالإنسان في أصل تكوينه، وهي كما

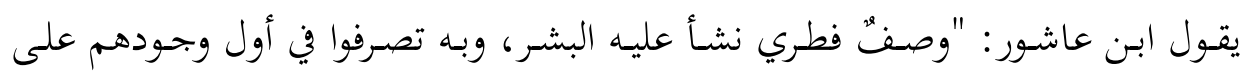
الأرض، حتى حدثت بينهم المزاحمة فحدث التحجير."

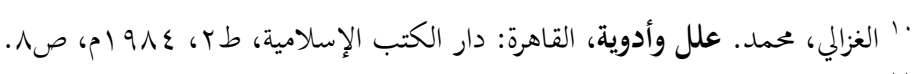

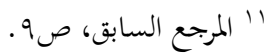

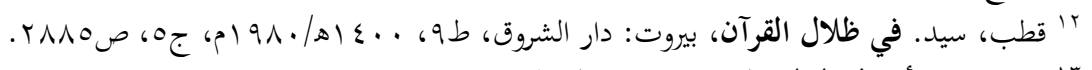

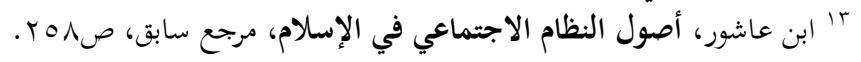




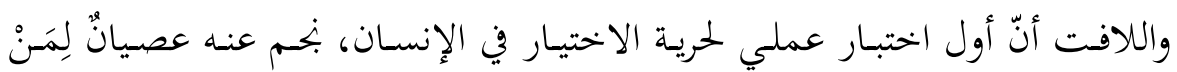

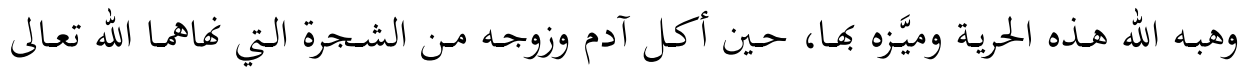

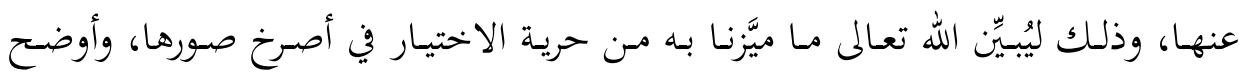

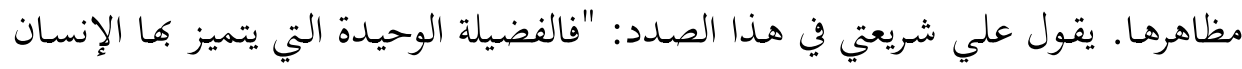

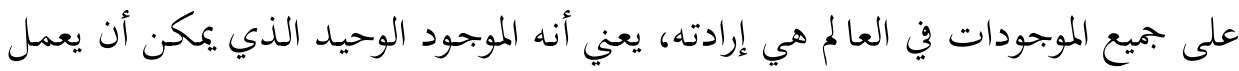

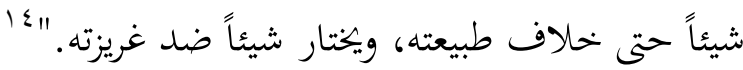

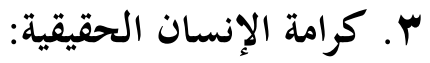

إنّ مظـاهر التكريم المـادي، وتمييز الإنسـان بـالإرادة وحريـة الاختيـار، كـان إيـذاناً

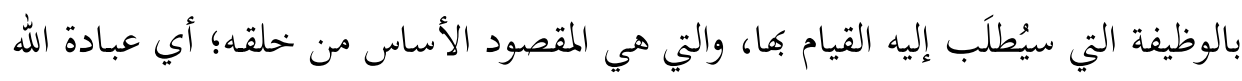

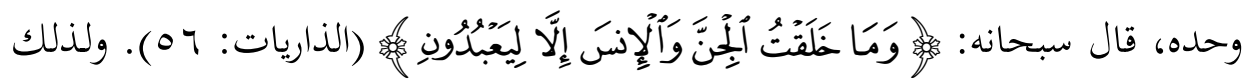

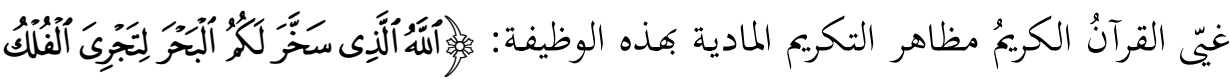

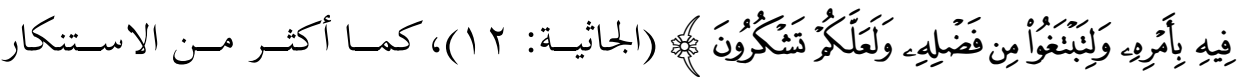

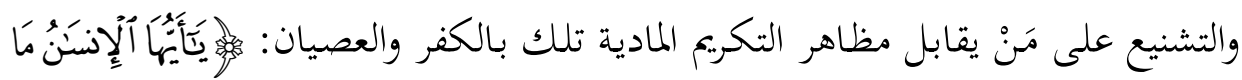

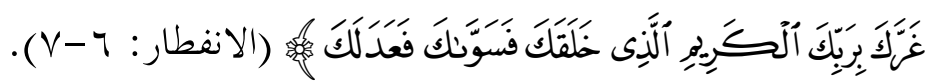

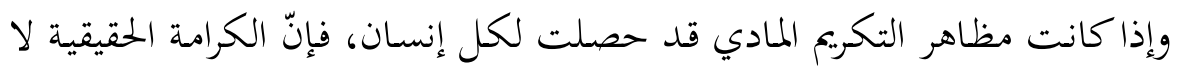

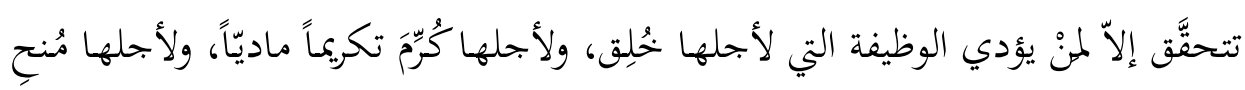

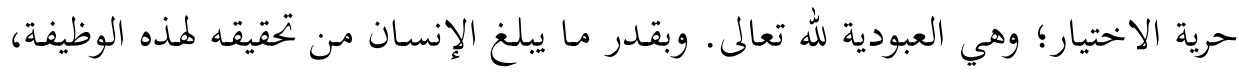

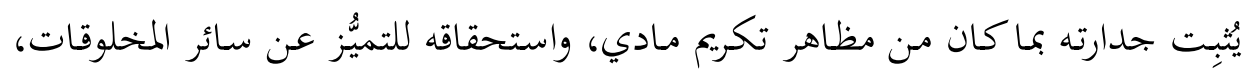

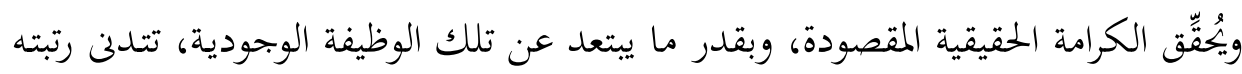

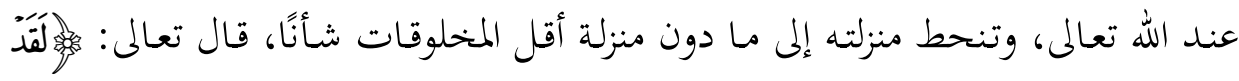

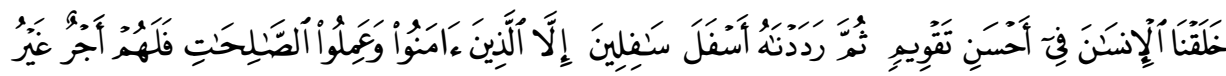

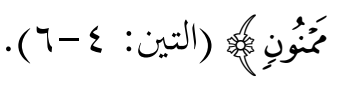

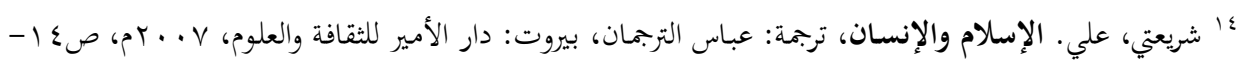




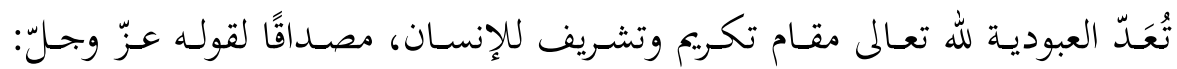

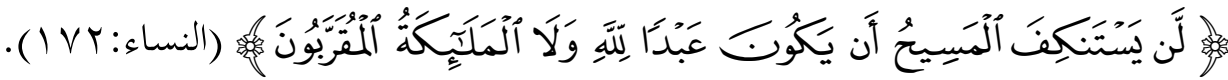

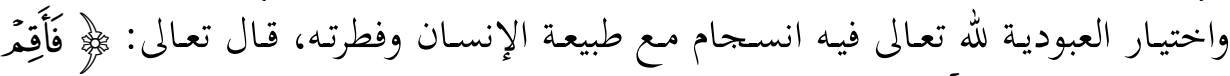

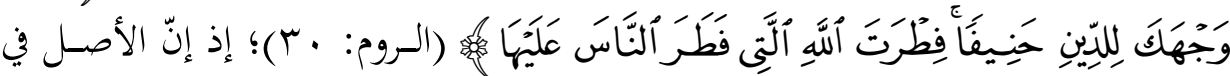

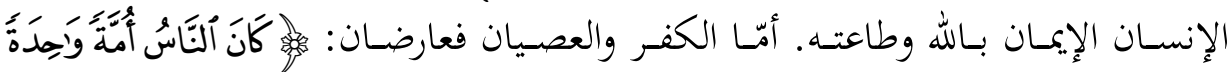

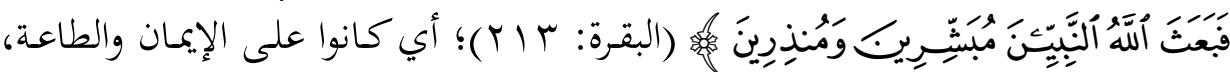

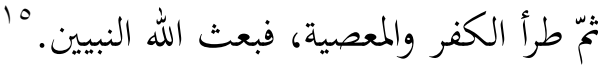

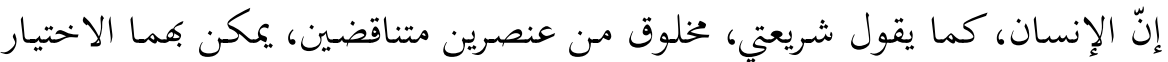

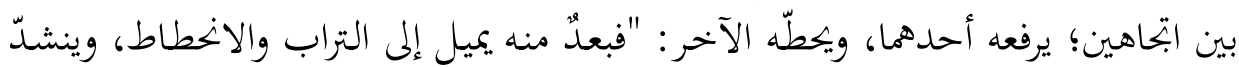

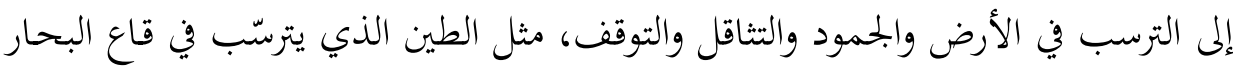

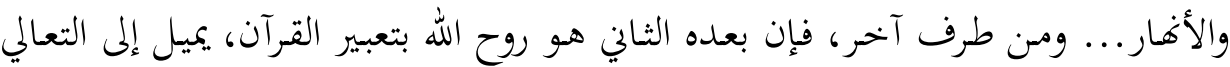

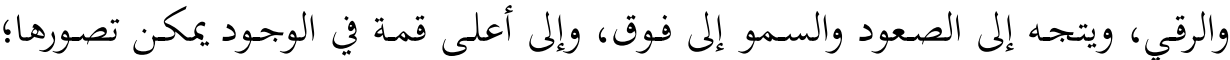

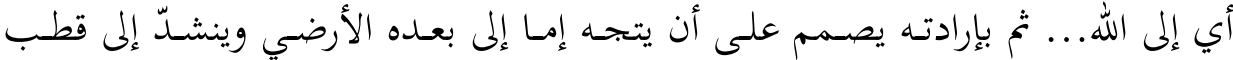

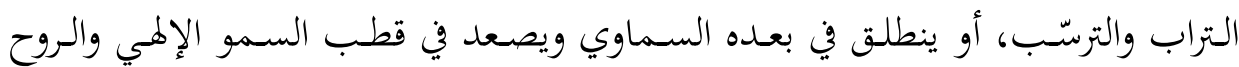

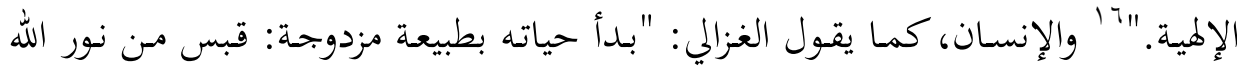

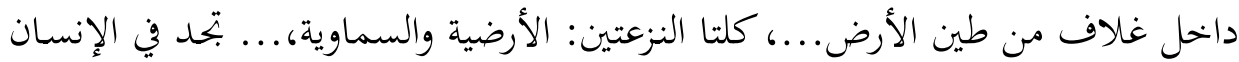

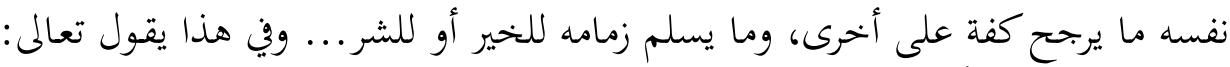

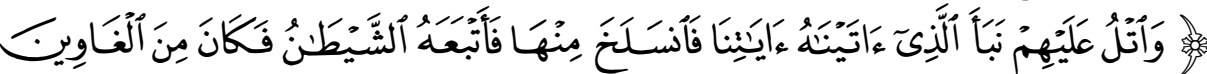

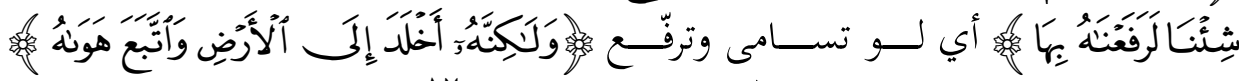

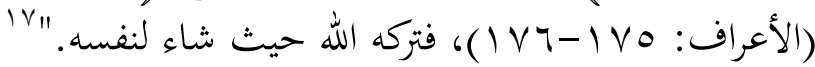

\section{ع. حرية الإنسان الحقيقية:}

إنّ ما يشعر به الإنسان من إرادة وقدرة على الاختيار، إنّا هو شعور بميزة خحَلقية

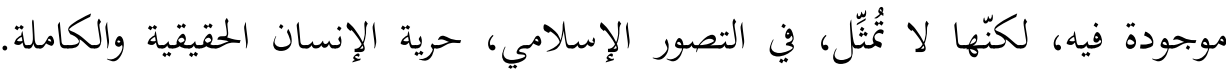
مُ الطبري، محمد بن جرير. جامع البيان في تأويل آي القرآن (تفسير الطبري)، بيروت: دار الكتب العلمية، طس، .

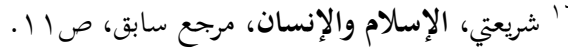

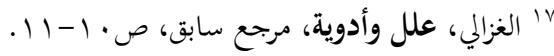




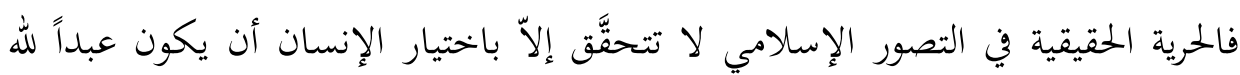

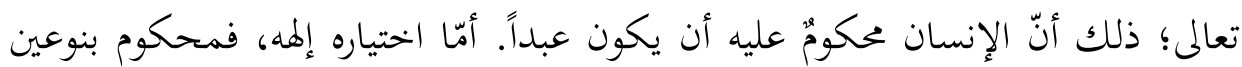

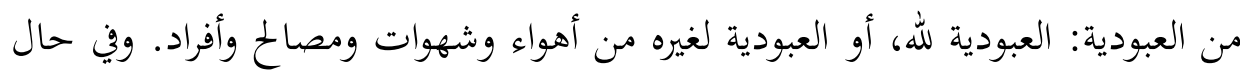

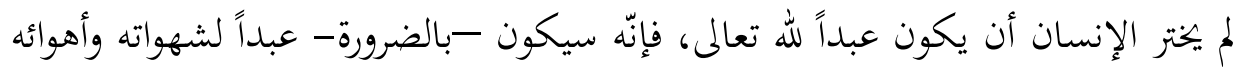

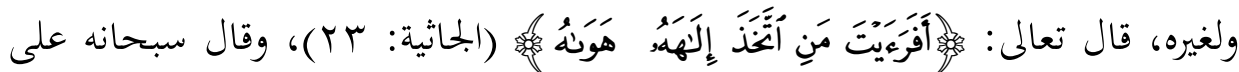

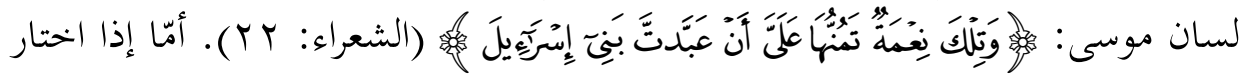

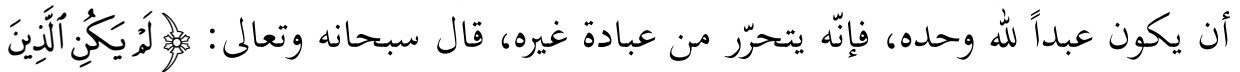

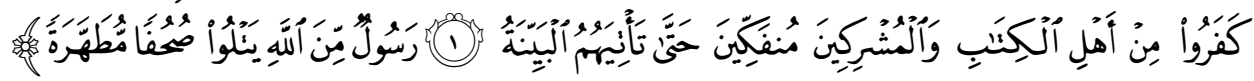

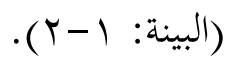

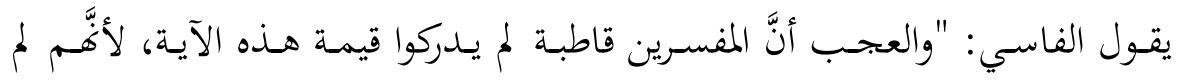

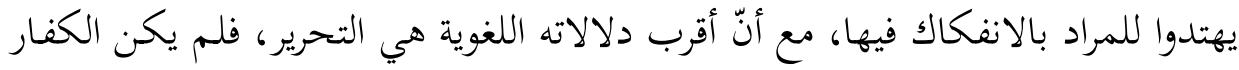

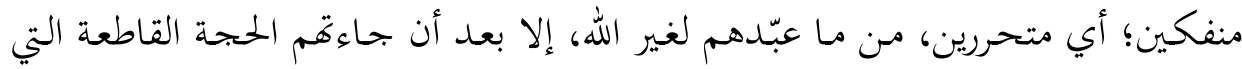

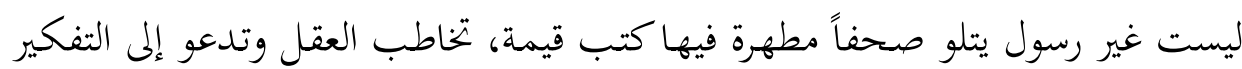

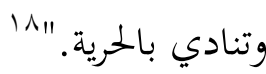

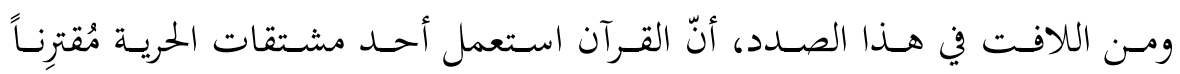

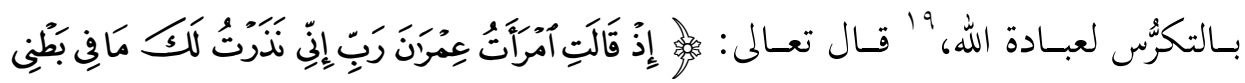

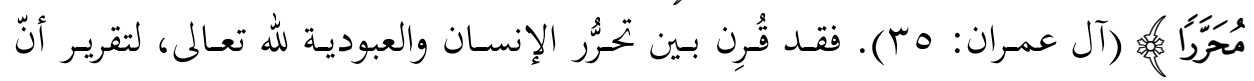

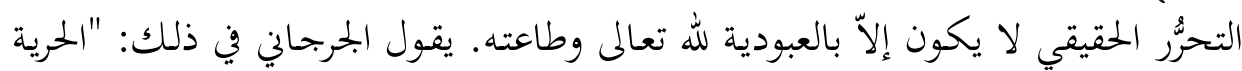

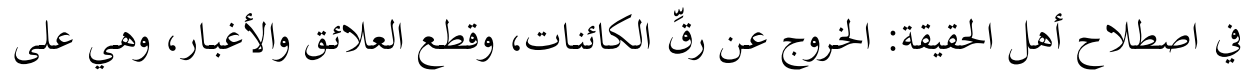

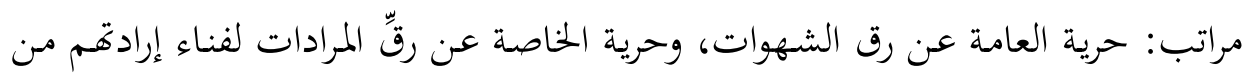

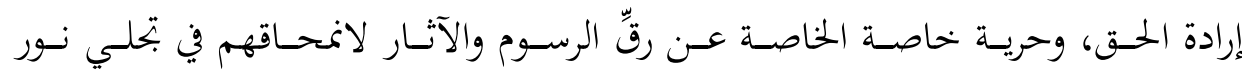

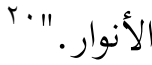

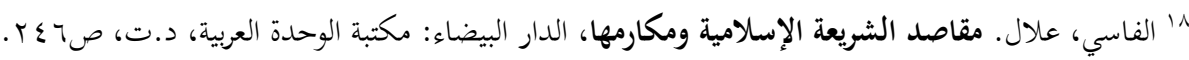

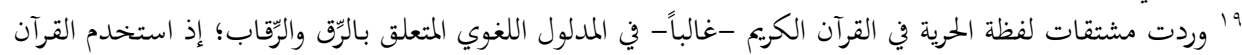

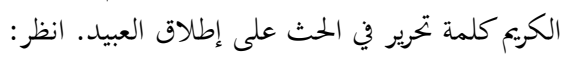

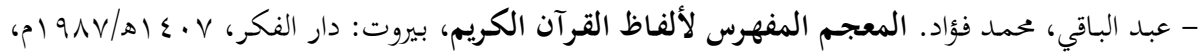

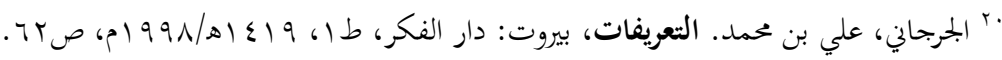




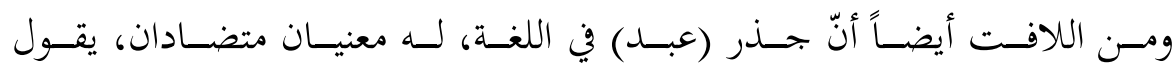

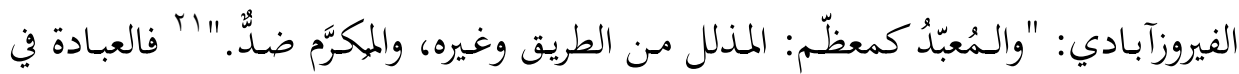

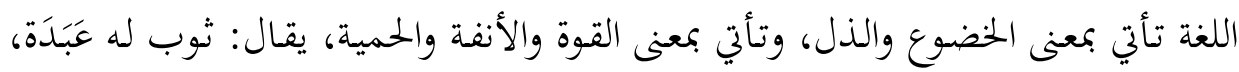

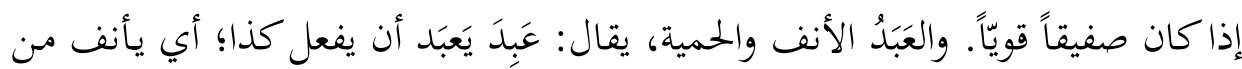

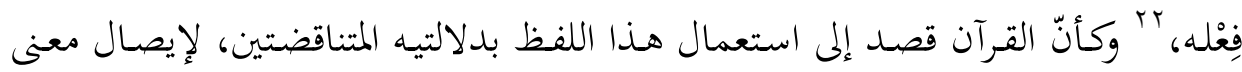

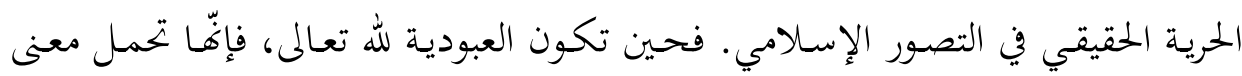

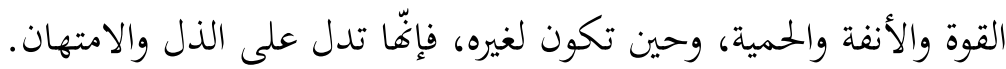

\section{•. مركزية مقصد حرية الإنسان:}

يُقترِّر علماء المقاصد أنّ المقصد الأول مـن مقاصد الشرع هو الدين، أو أن يكون

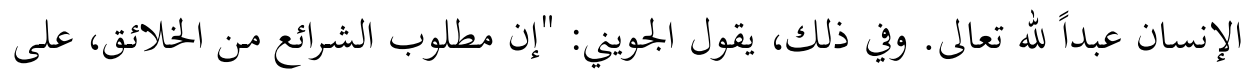

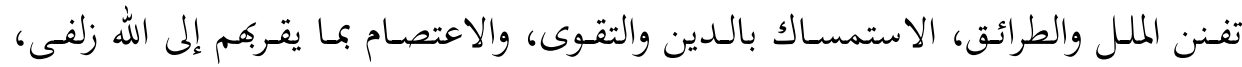

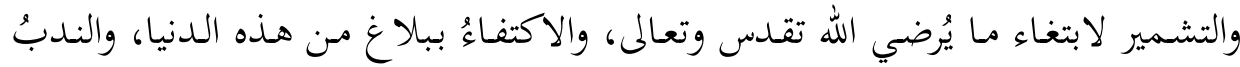

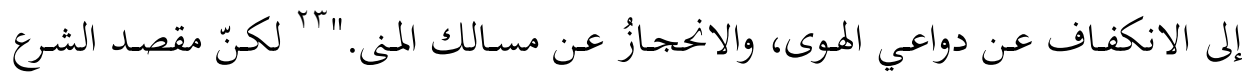

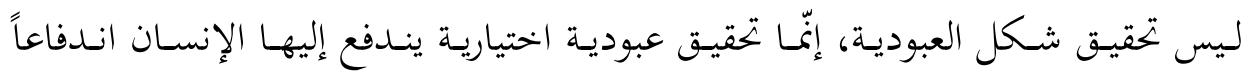

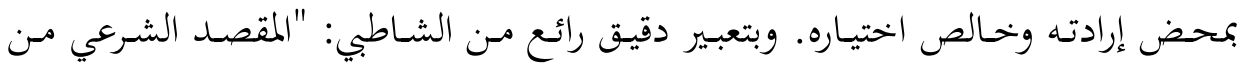

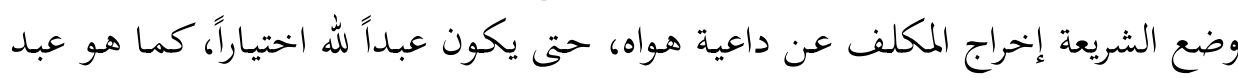

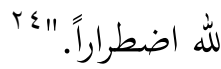

إنّ العبودية الاختيارية هي ما يُميّز الإنسان عن غيره، حتى عن الملائكة، ولأجلها

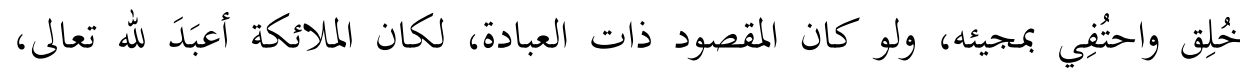

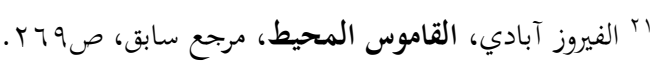

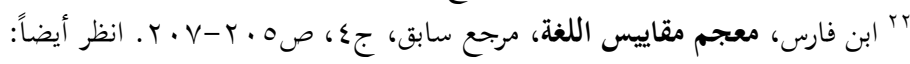

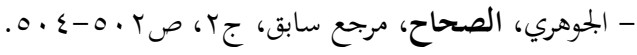

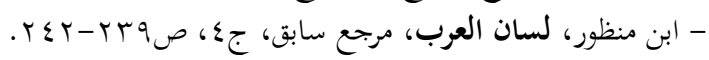

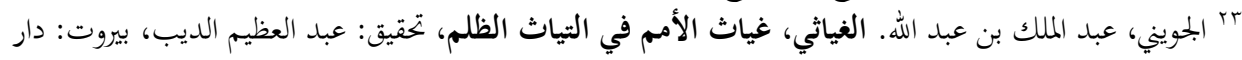

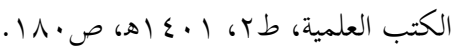

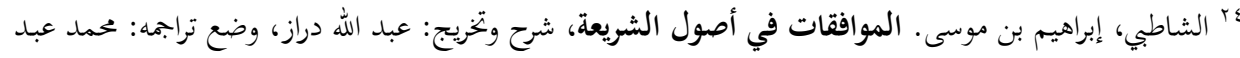

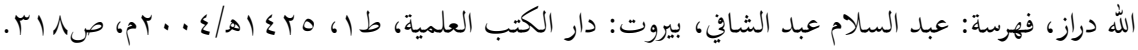




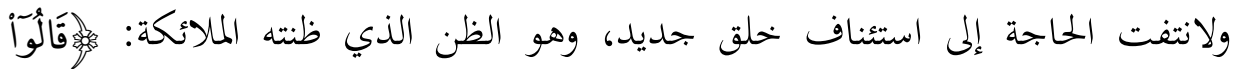

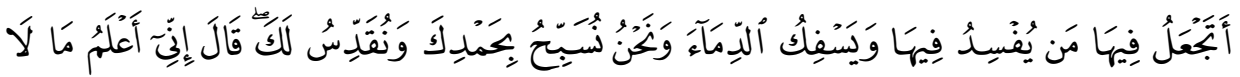

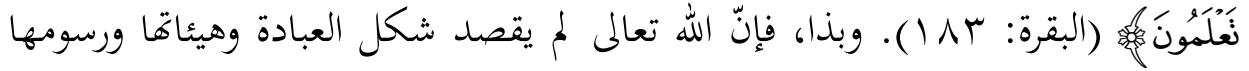

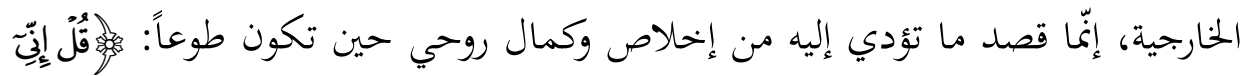

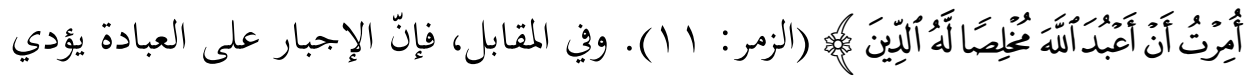

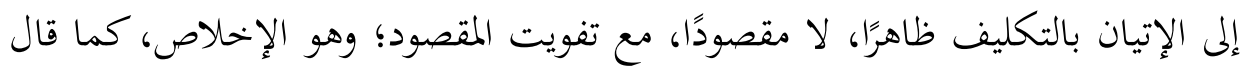

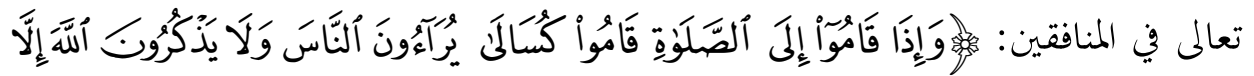

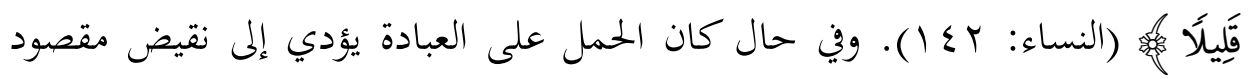

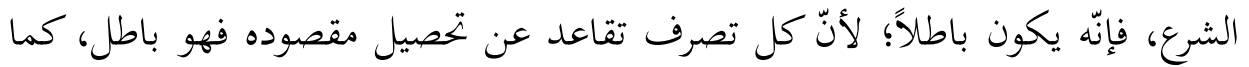

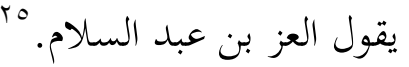
وهـذا يقتضـي إعـادة النظر في صـياغة مقصـد الشـريعة الأول، الذـي يـكره علمـاء

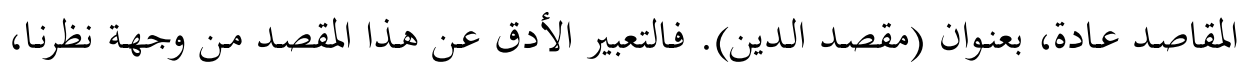

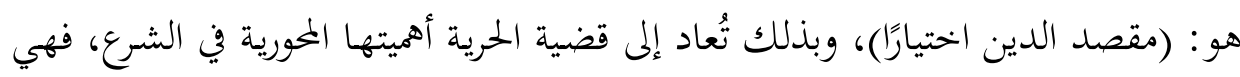

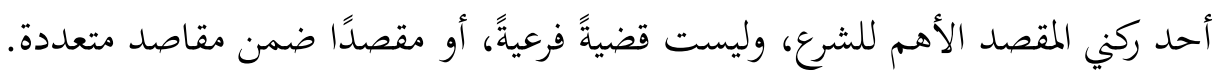

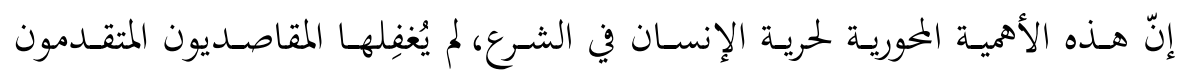

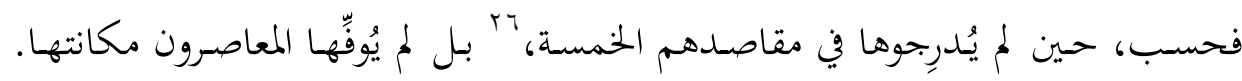

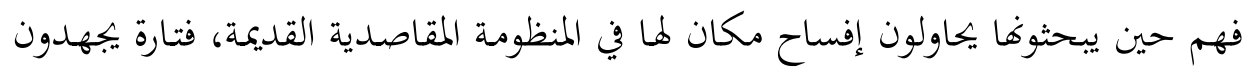

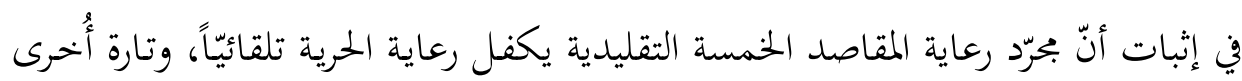

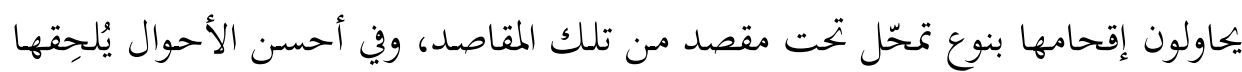

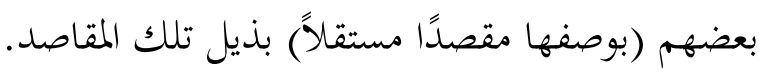
•r بابن عبد السلام، عز الدين عبد العزيز. . قواعد الأحكام في مصالح الأنام، القاهرة: مكتبة الكليات الأزهرية،

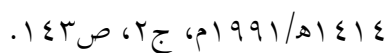

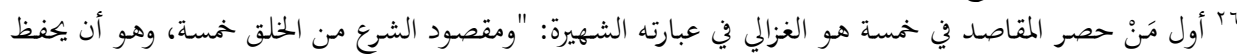

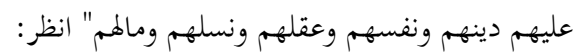

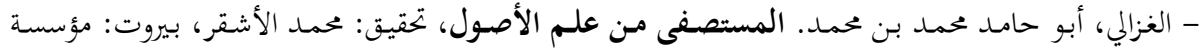

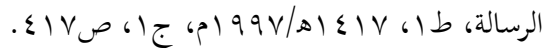




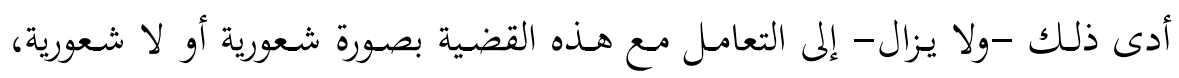
كأفّا قضية فرعية طارئة، لا تستدعي إعادة النظر في المنظومة المقاصدية القديمة، ويمكن فئن

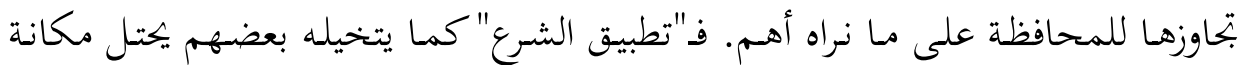

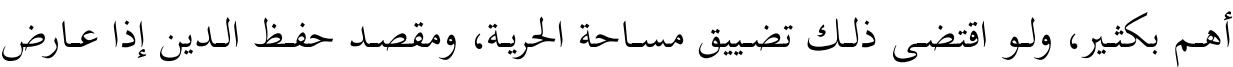

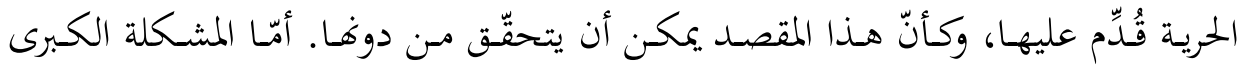

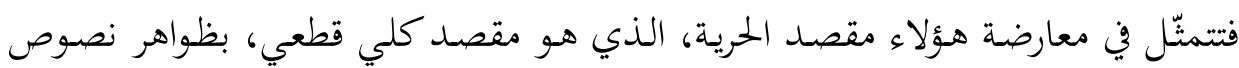

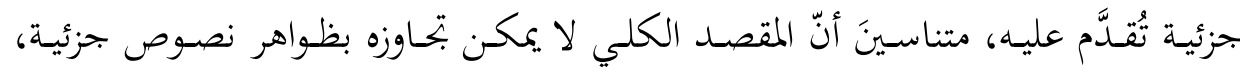

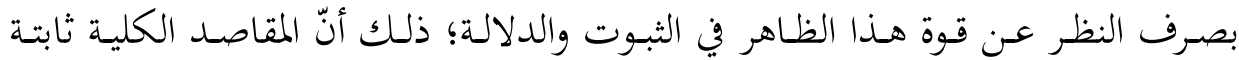

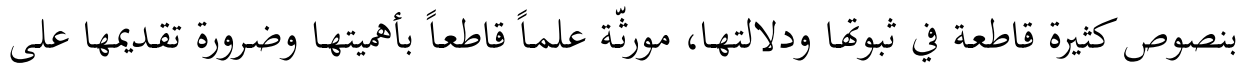
كل ما يعارضها. ويَ واقع الأمر، فنحن لا نزعم أنّ الحرية يجبـ أن تكون مطلقـة، ولا نُنكِر إمكانية

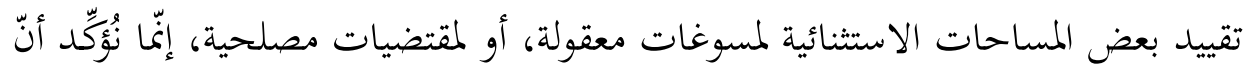
التصور الحالي لقضية الحرية، وعدم إدراك محوريتها وأهميتها في التصور الشرعي، يُفضي إلى إلى

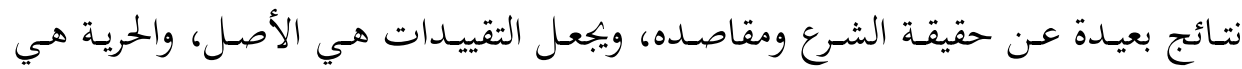

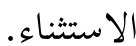

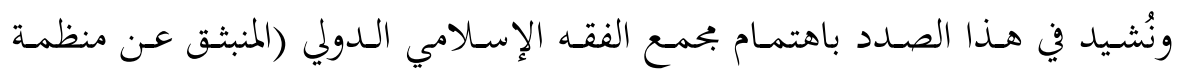

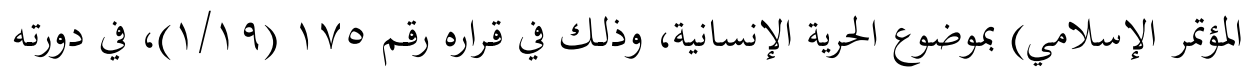

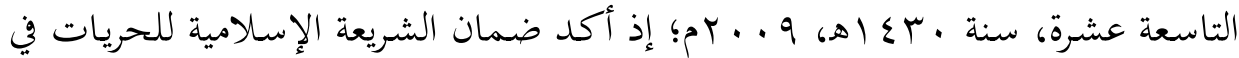

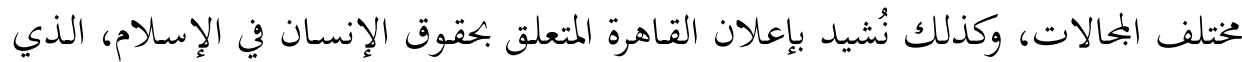

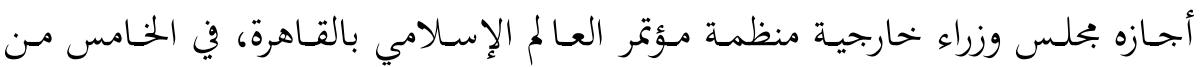

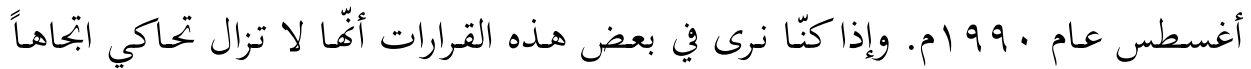

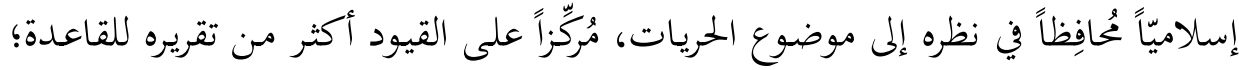

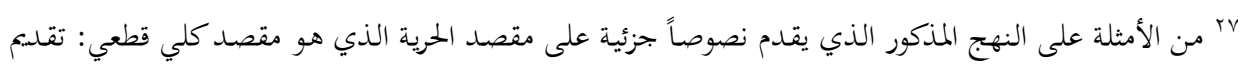

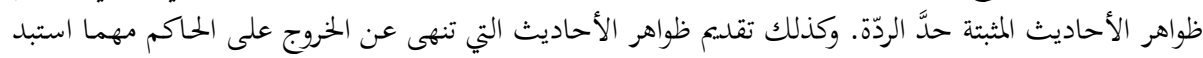

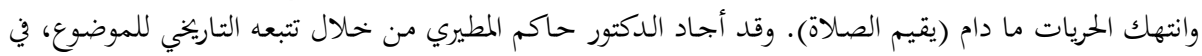

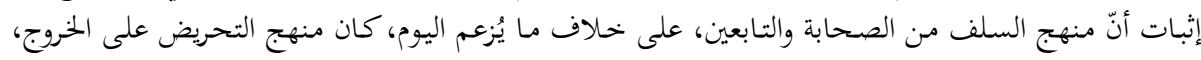

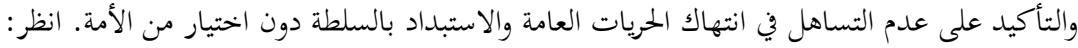

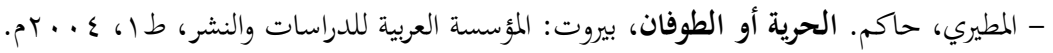




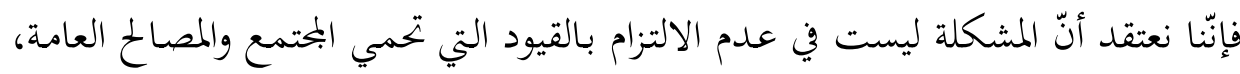

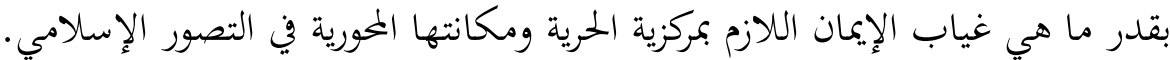

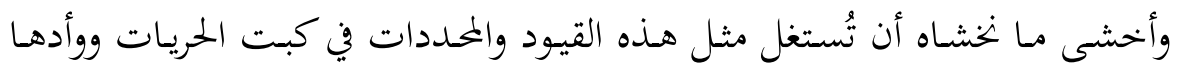

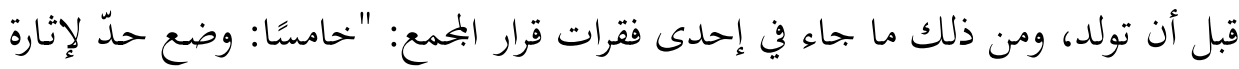

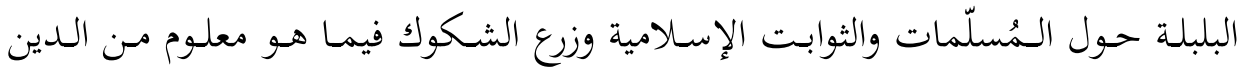

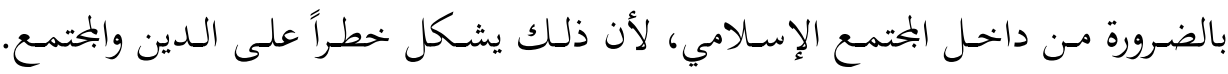

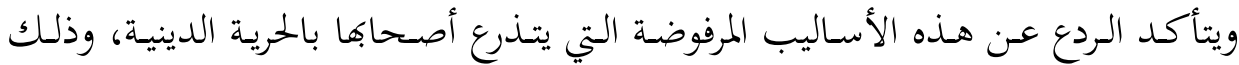

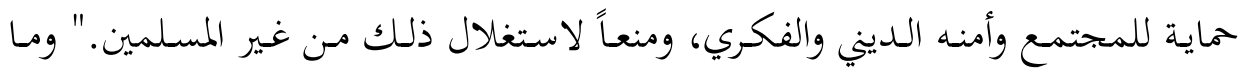

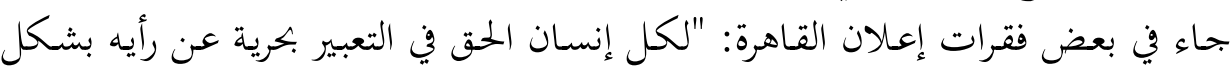

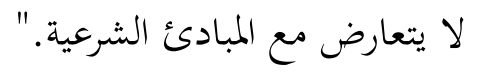
فـنحن نـرى أنّ مثل هـذه الروح المحافظة لا تتوافق ومحوريـة قضسية الحريـة في التصـور

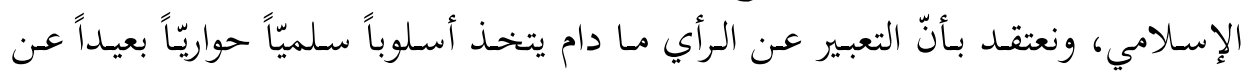

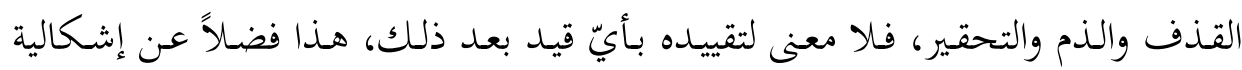

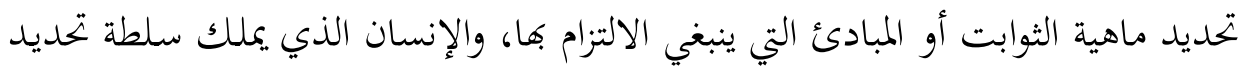

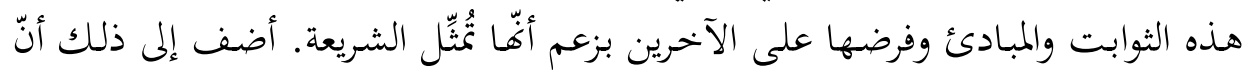

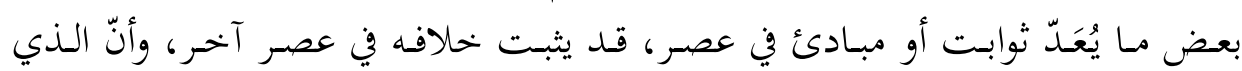

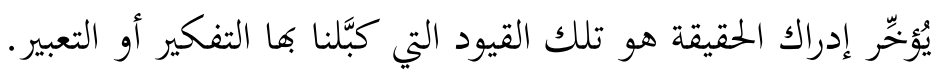

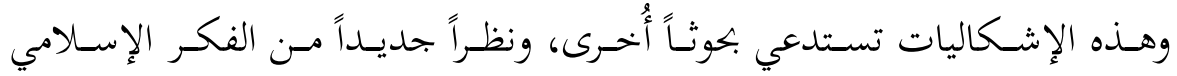

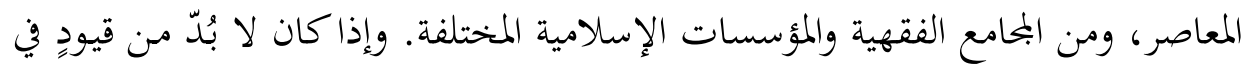
مثل القرارات والإعلانات المذكورة، فيجب أن تكون محددة في عددها وفي المقصود منها،

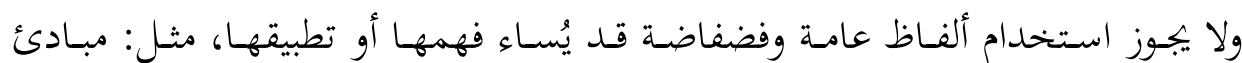
الشريعة، وثوابت الشريعة.

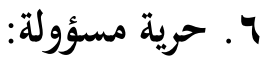

لا شكّ في أنّ اختيار الإنسان وحريته مقيدان زماناً بالحياة الدنيا، وأنّه سوف يُسأَل

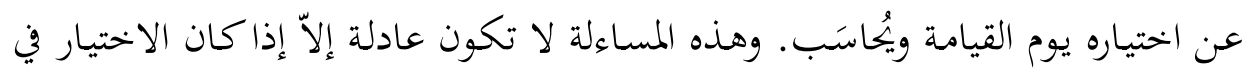

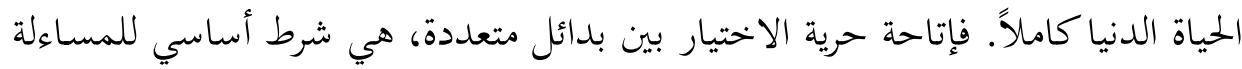




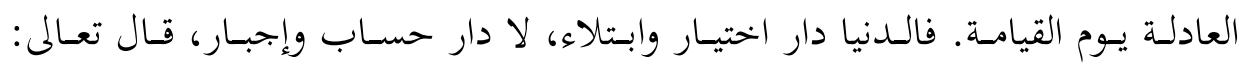

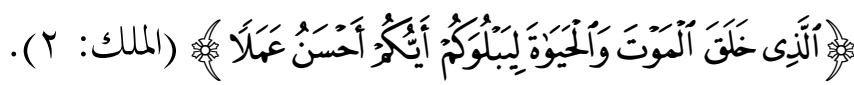

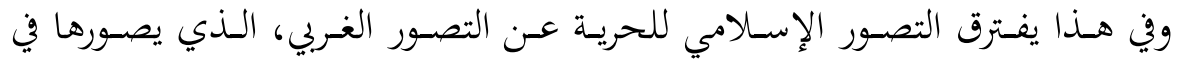

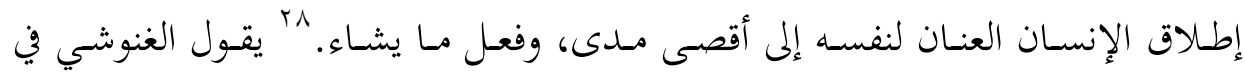

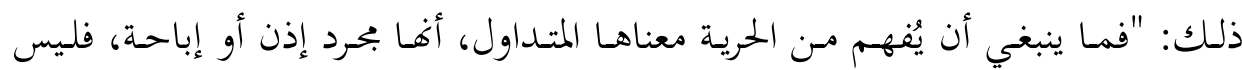

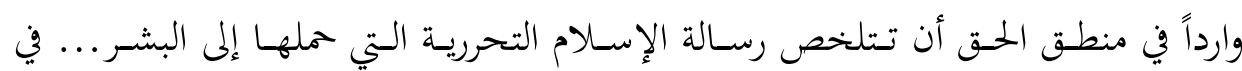

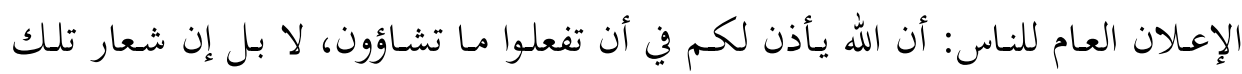

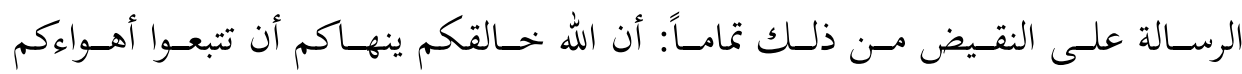

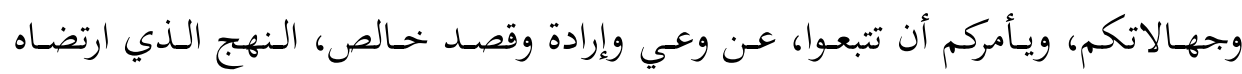

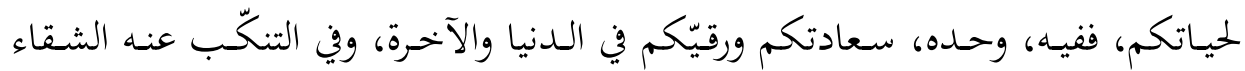

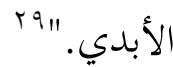

\section{ثالثًا: قواعد الإلزام في السياسة الثرعية}

يتعيّن على السياسة الشرعية، بوصفها السياسة المنسوبة إلى الشرع، تحديد مقاصدها

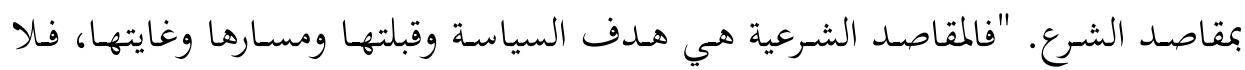

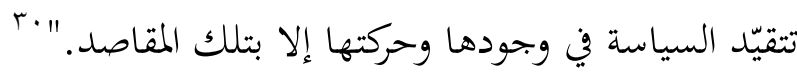

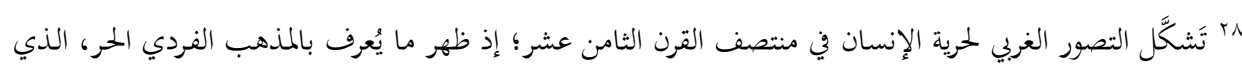

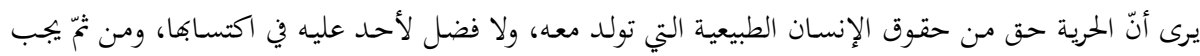

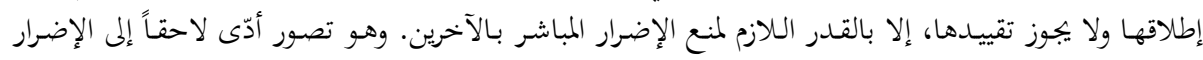

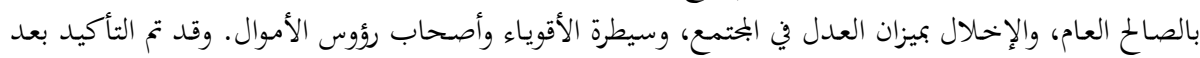

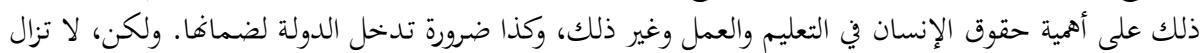

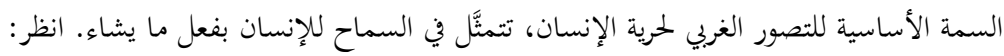

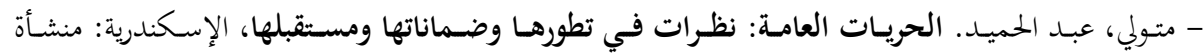

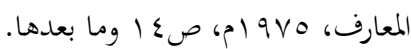

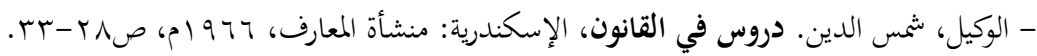

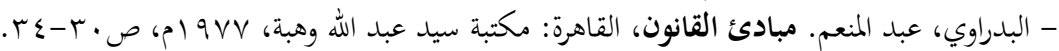

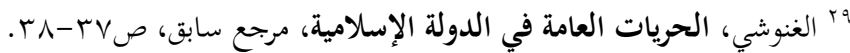

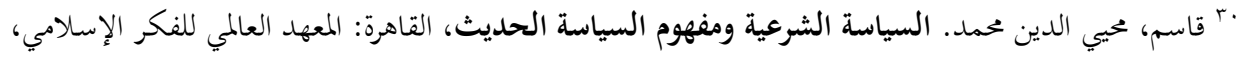

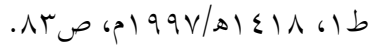


والمقصـد الأول للشـرع هـو مقصــــ "العبوديـة الاختياريـة لله تعـالى"؛ أي أن يكـون الإنسان عبداً لله اختياراً، وهذا هو المقصد الأول للسياسة الشرعية.

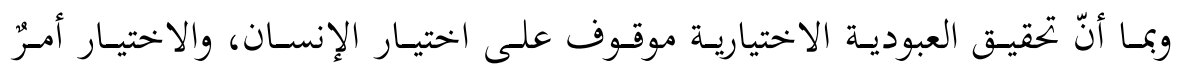

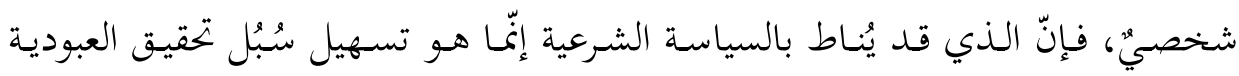

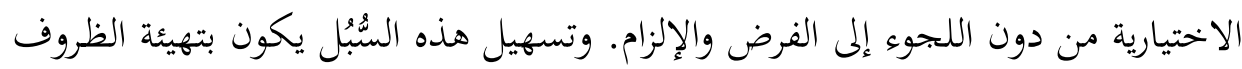

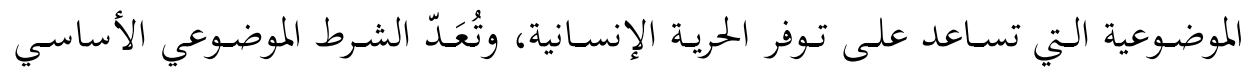

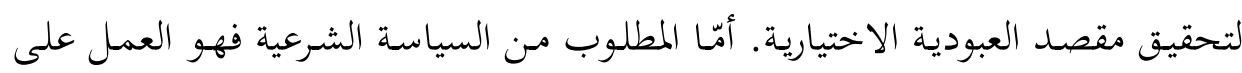

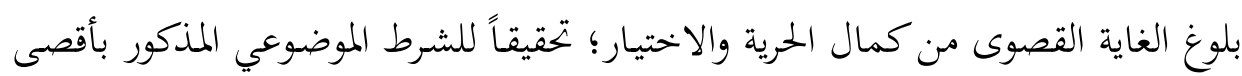

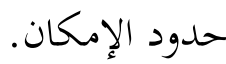

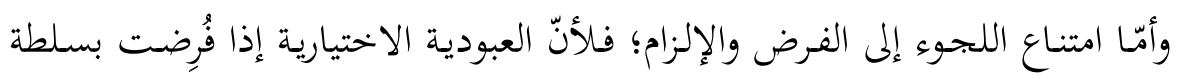

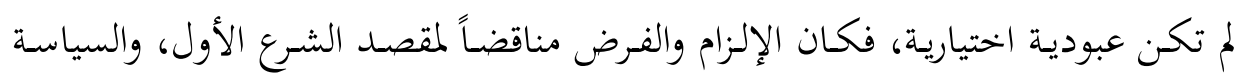

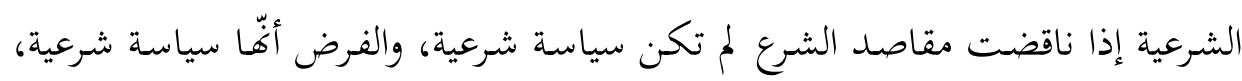

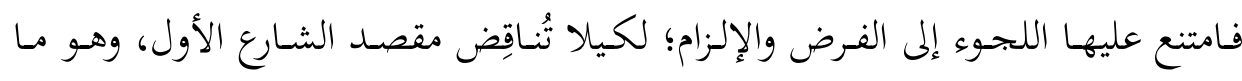

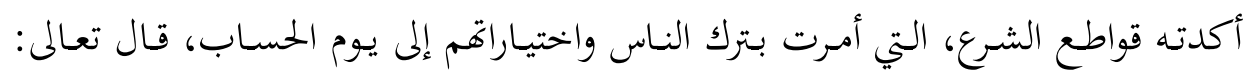

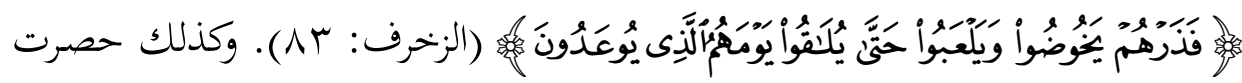

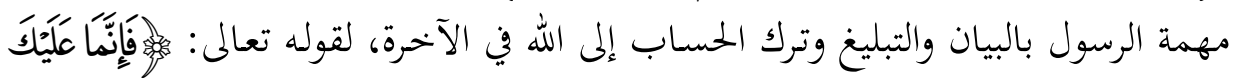

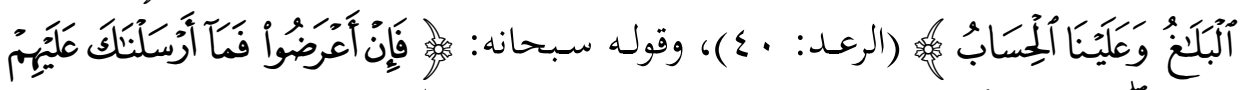

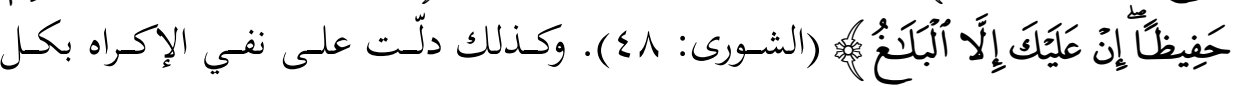

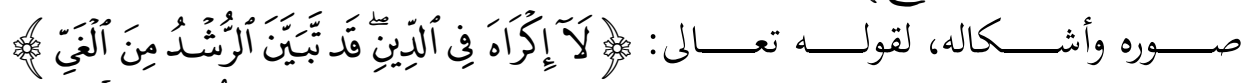

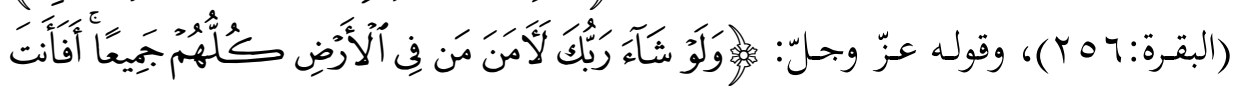

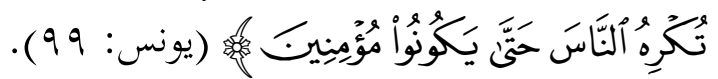

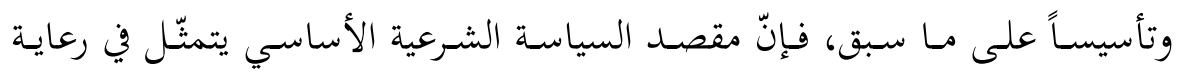

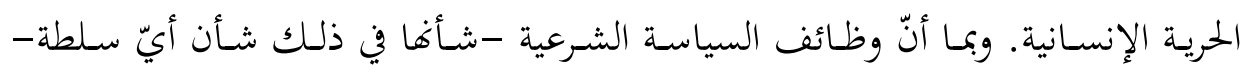

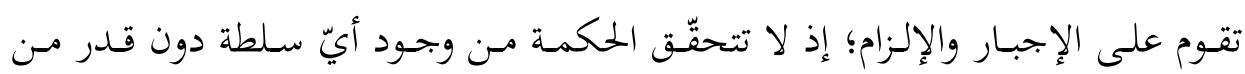

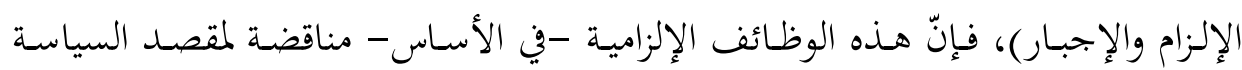


الشـرعية الأول (رعايـة الحرية الإنسـانية). وينبني على ذلك أمـران؛ أوهمـا: إنّ الإلزام في

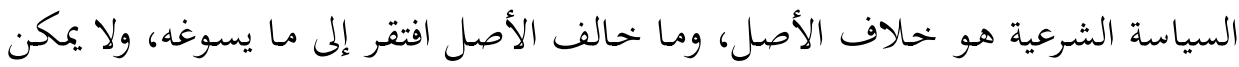

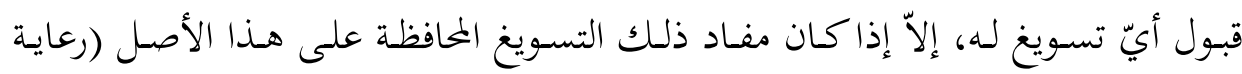
حرية الإنسان)؛ ذلك أنّ مقصد السياسة الشرعية الأول لا يتقدّم عليه شيء في الاعتبار

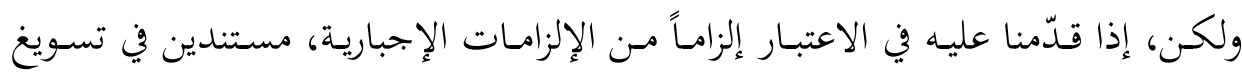
تقديمه إلى ذلك المقصد، كان ذلك تقديماً لهذا المقصد على ذلك الإلزام حقيقةً، وإن كان إلى إنسان في الصورة تقديُء لذلك الإلزام على ذلك المقصد، والعبرة بالحقيقة لا بالصورة. لذا، يتعيّن على إلزامات السياسة الشرعية أن تكون خادمة لمقصد السياسة الشرعية

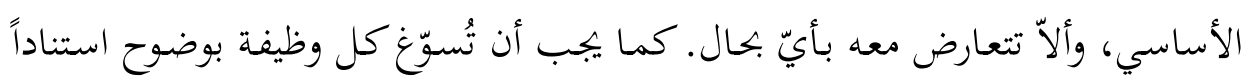

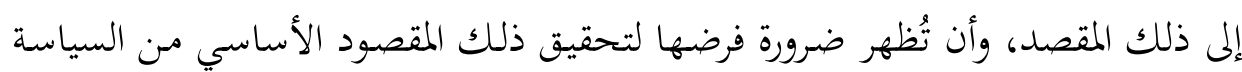

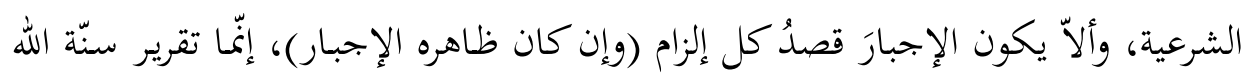
تعالى في جعل الإنسان مختاراً في الحياة الدنيا.

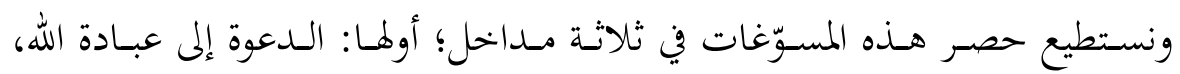

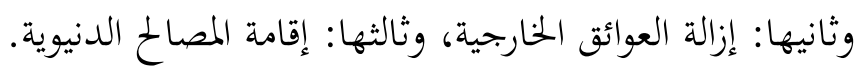

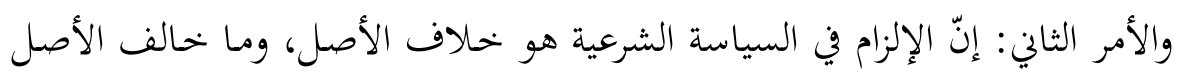

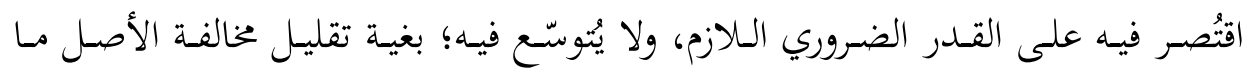

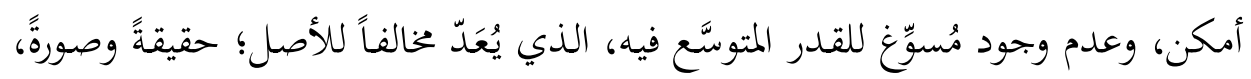
فامتُع، وهذا ما يمكن أن نطلق عليه تعبير "تقليل الإلزامات الإجبارية".

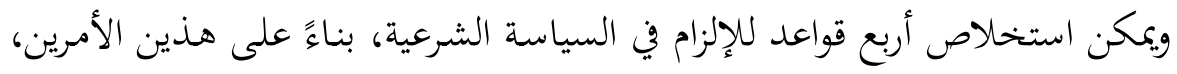

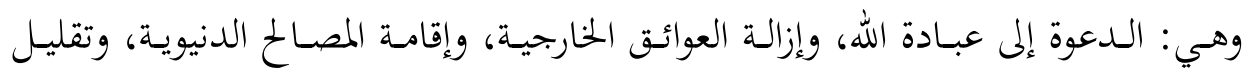
الإلزامات الإجبارية.

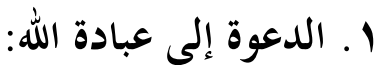

وُجِدَ الإنسـان وَفق التصور الإسـلامي ليعبد الله، كمـا أراد الله منه، وفي ذلك خحيره وسعادته في الدنيا والآخرة، وهو مسؤول عن ذلك يوم القيامة، ومسؤول عن اختياراته الإنه 


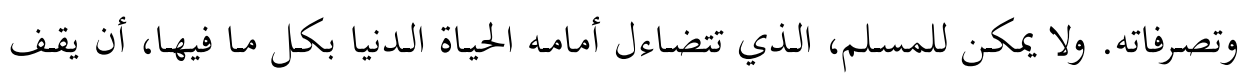

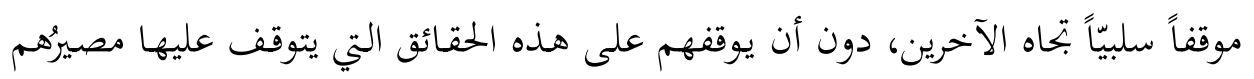

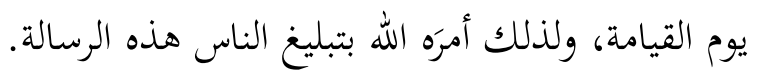

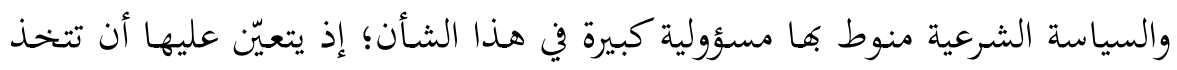

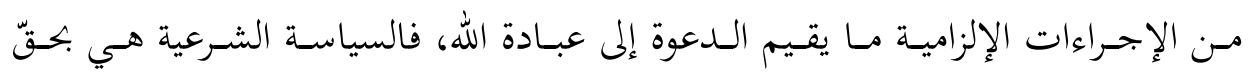

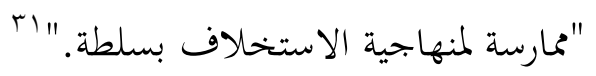

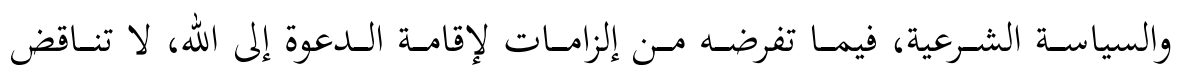

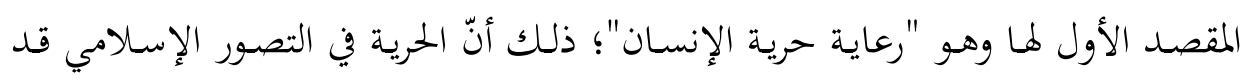

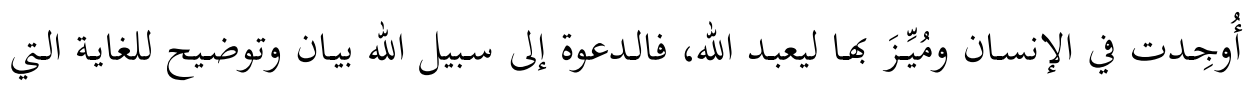

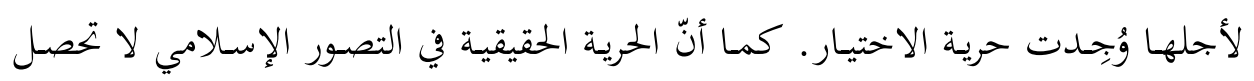

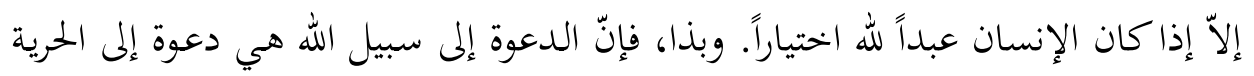

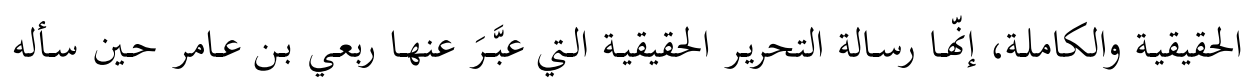

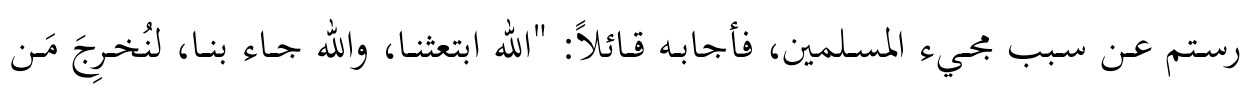

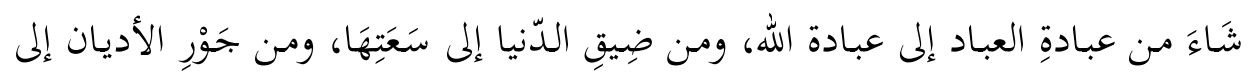

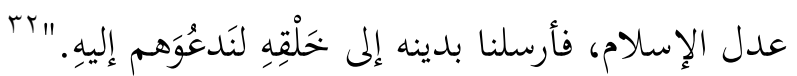

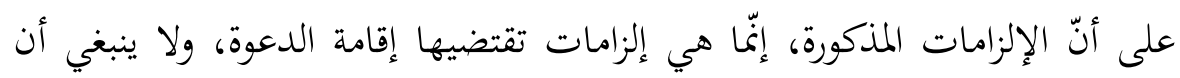

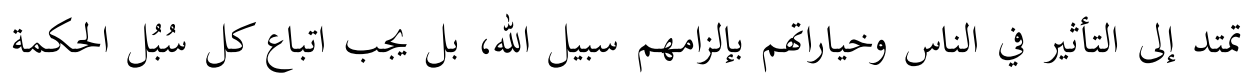

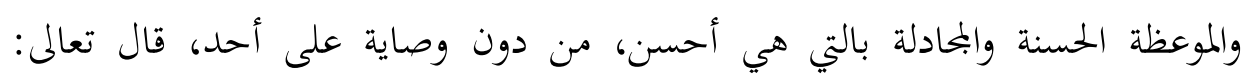

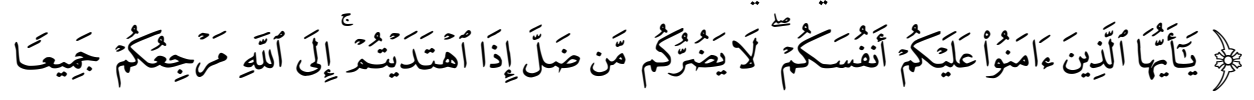

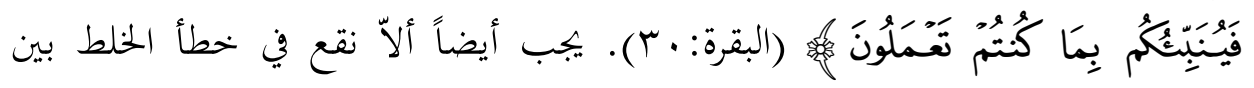

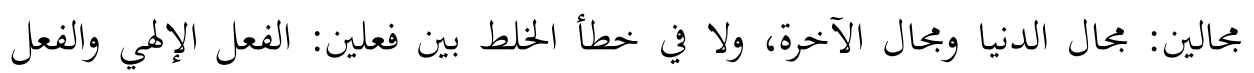

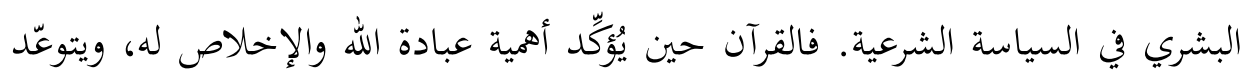

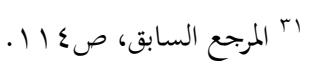

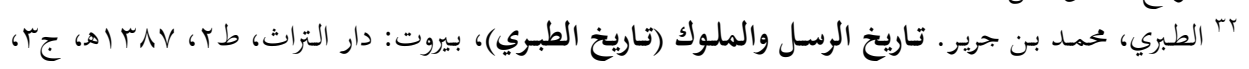


على ذلك مَنْ لا يمتثل ويتهدَّدُه، فإنّ بحال ذلك هو الآخرة لا الدنيا، ومُنفّذْ تلك التوعَدات والتهديدات هو الله تعالى وليس الناس، ولا يجوز للسياسة الشرعية أن تحاكي ذلك أو تماثله، وإلاّ بحاوزت مقصدها الأساسي المتمثّل في المحافظة على حرية الإنسان،

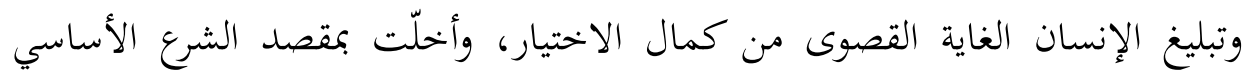
المتمثّل في تحقيق العبودية الاختيارية.

يتضـح مـن ذلك أنّ التصور الإسـلامي لحريـة الإنسـان القـائم على تحقيق العبوديـة

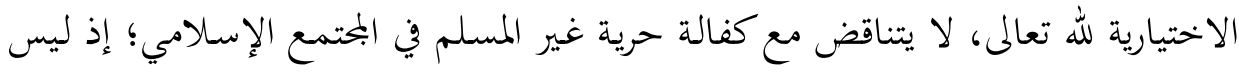

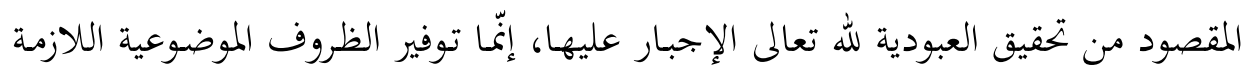

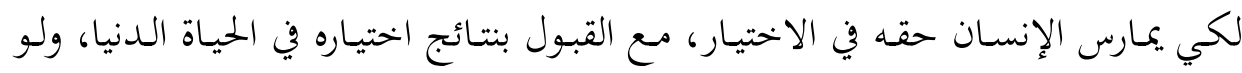

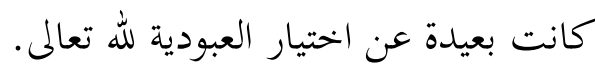

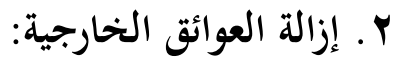

توجد صوارف خارجية تُؤثِّ في الإنسان سلباً بابتحاه الغي والضلال، وتُغريه باختيار

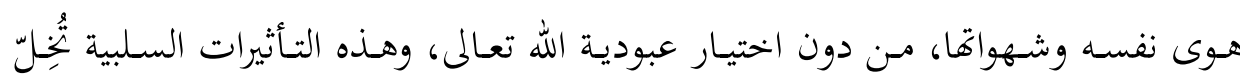
بكمال الاختيار الإنساني. وبما أنّ مقصد السياسة الشرعية الأول هو المحافظة على حرية

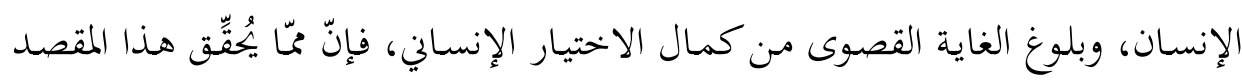

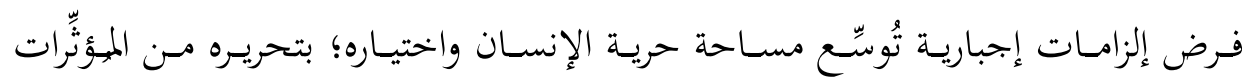

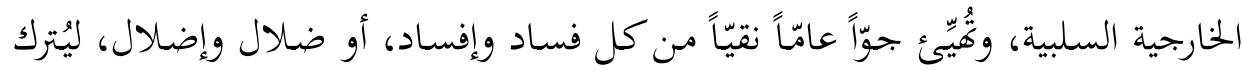
الإنسان واختياره المخض.

وينسجم ذلك مع تصور الإسلام للحرية الحقيقية، أفّا لا تتحقّق إلاّ بتحُرّر الإنسان من الأهواء والشهوات والمؤثِّرات السلبية. وقـد أشـار عليه السـلام إلى أثتر العوائق الخارجيـة في إرادة الإنسـان واختياراته، فيما

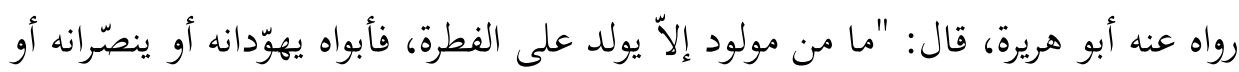

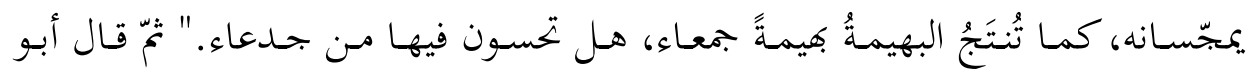




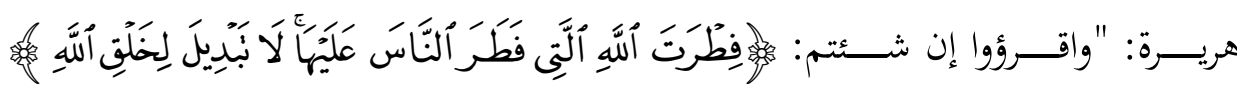

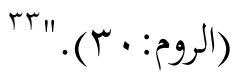

يقول الزخشري: "والمعنى أنه خلقهم قابلين للتوحيد ودين الإسلام، غير نائين عنه ولا منكرين له، لكونه بحاوباً للعقل مساوقاً للنظر الصحيح، حتى لو ثُركوا لما اختاروا عليه ديناً آخر. "اءّ ويقول الغزالي: "وليس معنى الفطرة أنّ الناس يولدون بعقائدها وفضائلها، فلو كان الأمر كذلك ما كان هنالك تكاليف، وإنما المعنى أنّ الناس يولدون مستعدين لها مؤثرين لمنهجها، يتدافعون في بحراها تدافع الماء إلى منحدره، وأن عوائق مصطنعة هي التي تقطع طريقهم وتردهم عن وجهتهم، ترى ما هذه العوائق؟ إن الحميث الشريف أشار إلى

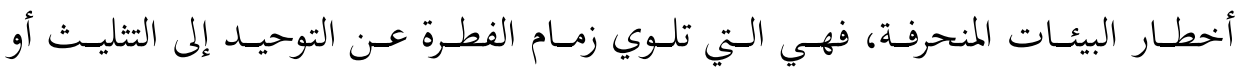

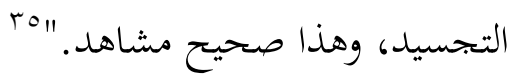

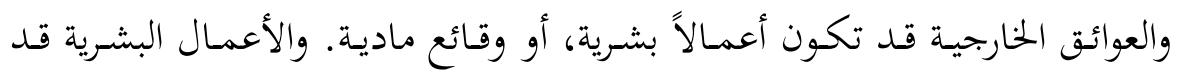
تكون داخلية، مثل إشهار الفواحش والمنكرات مُّن يرتكبوها، وقد تكون خارجية، مثل

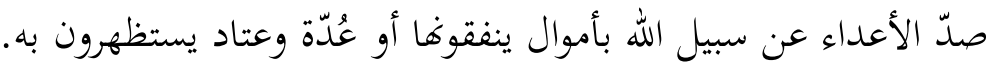
ويكون فعل السياسة الشرعية مع العوائق التي هي أعمال بشرية، باتخاذ الإجراءات

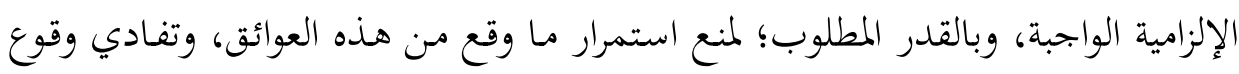

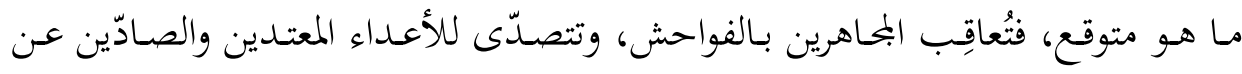
سبيل الله بالجهاد القتالي وغيره من وسائل الدفع السلمية، كالحرب الإعلامية والنفسية.

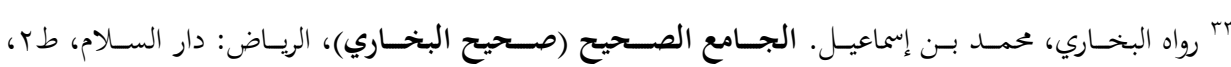

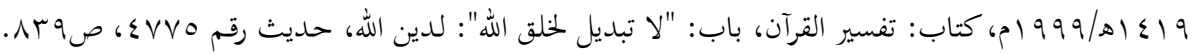

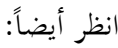

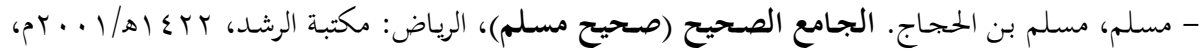

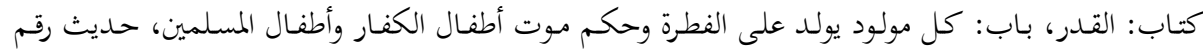

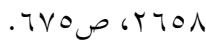

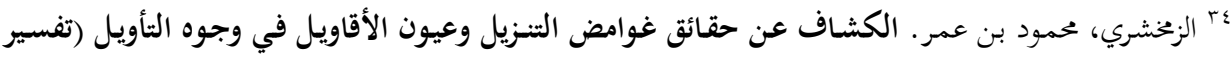

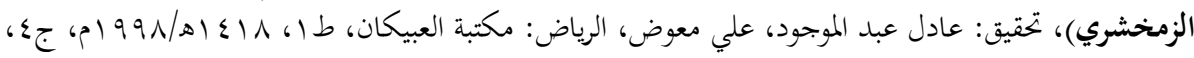
• الغزالي، علل وأدوية، مرجع سابق، ص. . . 


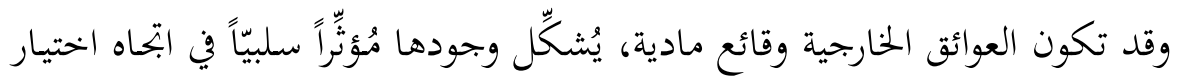

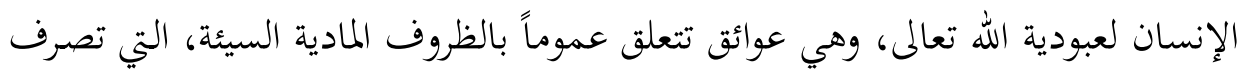

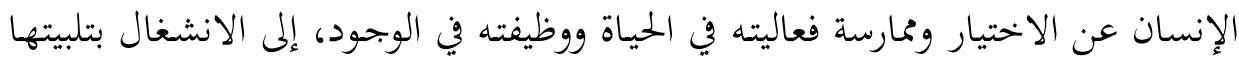

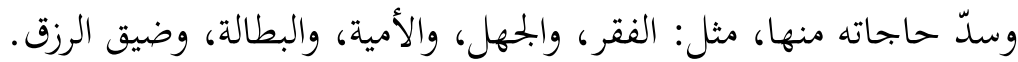

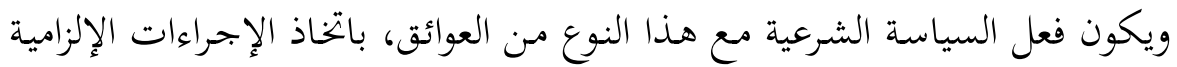

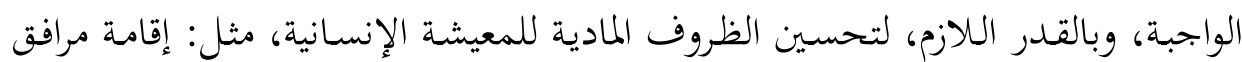
التعليم والصحة، وتوفير فرص العمل، ومساعدة المختاجين. ونورد فيما يأتي أمثلة على وظائف السياسة الشرعية، مثّا ظاهره الإجبار وحقيقته العيلن

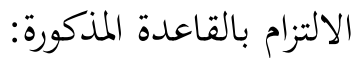

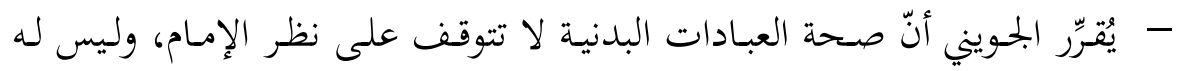

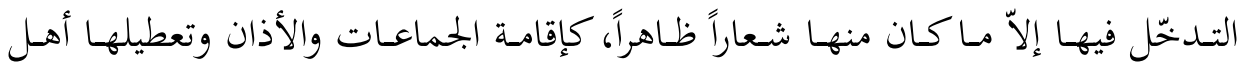

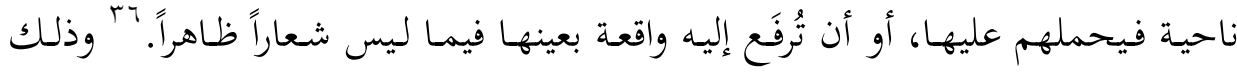

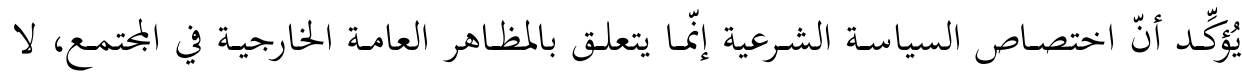

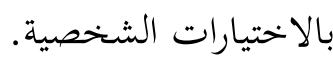

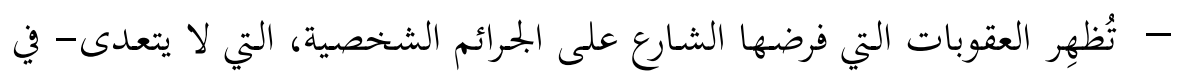

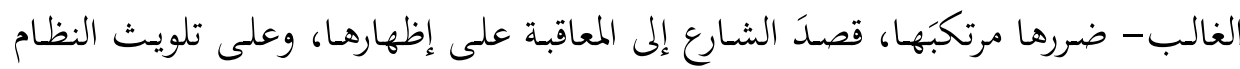

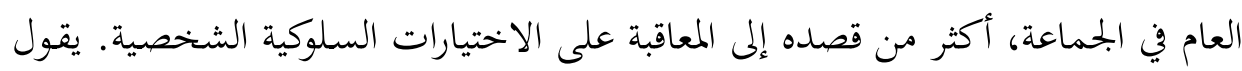

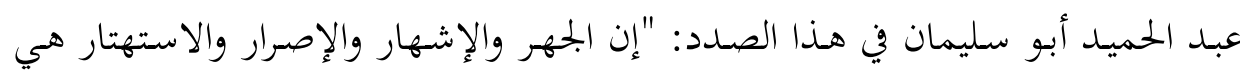

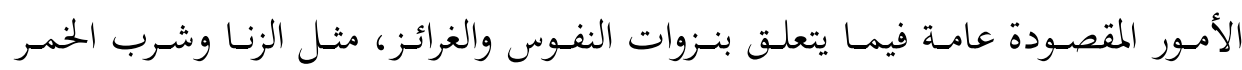

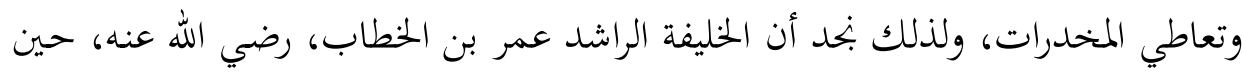

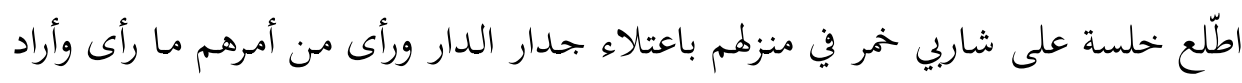

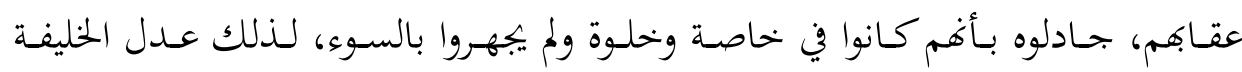

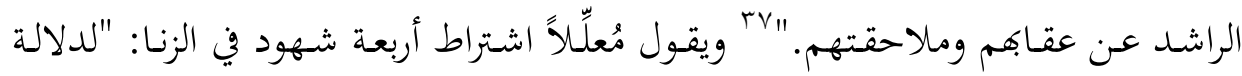

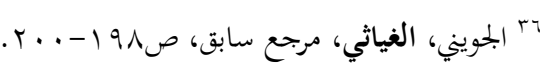

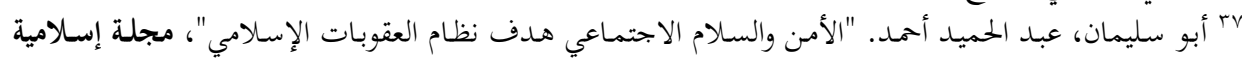

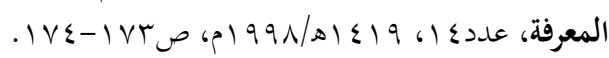




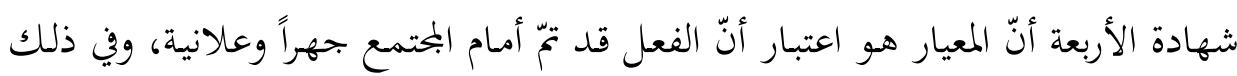

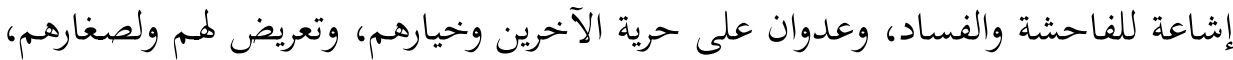

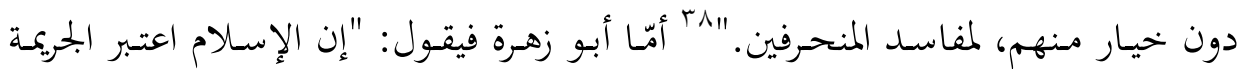

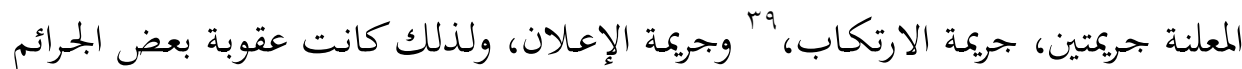

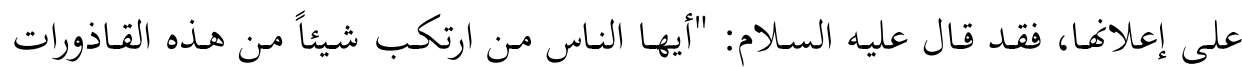

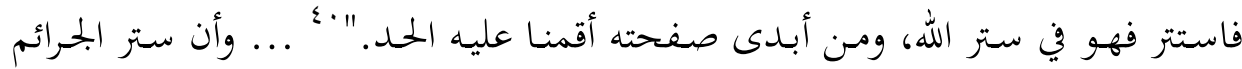

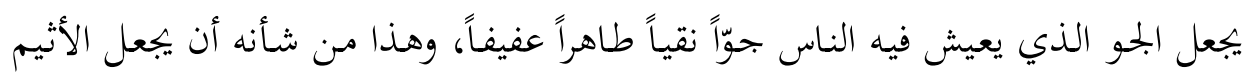

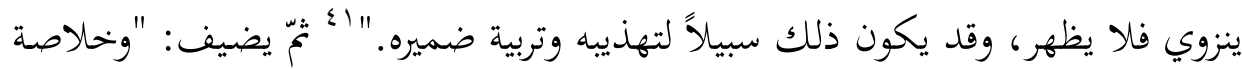

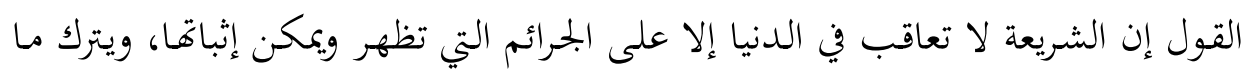

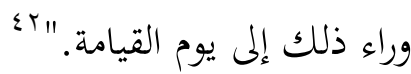
- رتَّب الإسلام عقوبة على جريمة القذف، ويَظهر في هذه الجريمة جليّاً قصدُ

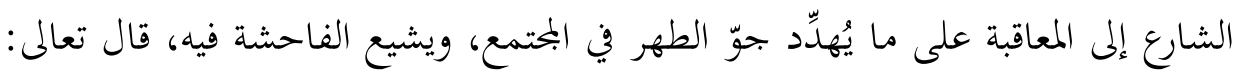

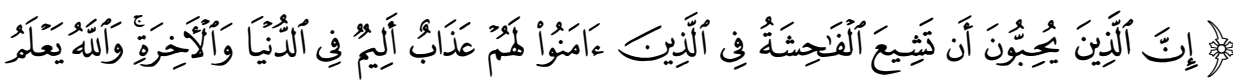

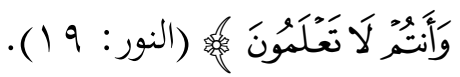
- قرَّر الشارع مبدأ الأمر بالمعروف والنهي عن المنكر، ويظهر من ذلك قصده إلى فئل

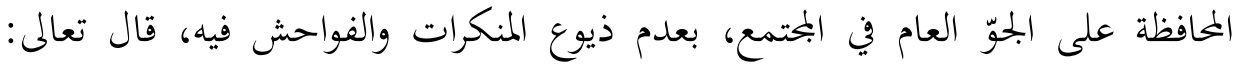

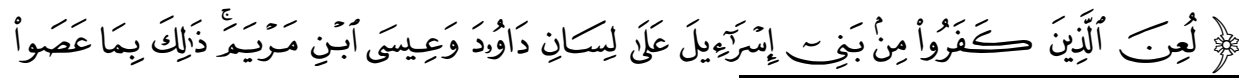

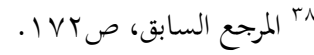

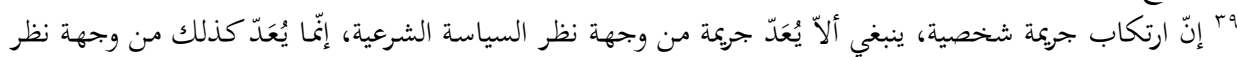

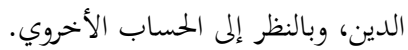

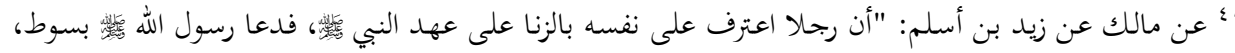

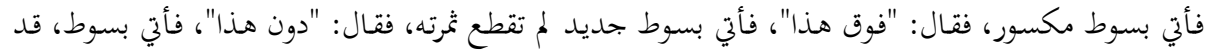

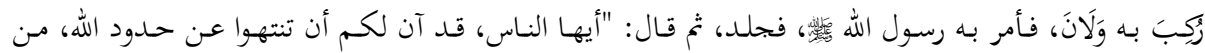

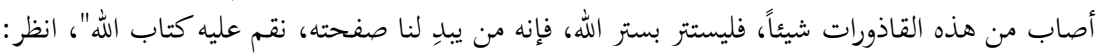

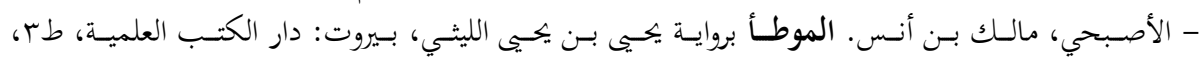

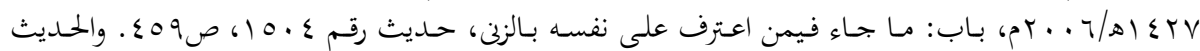

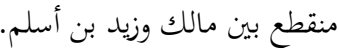

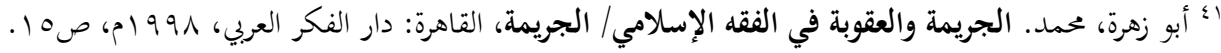

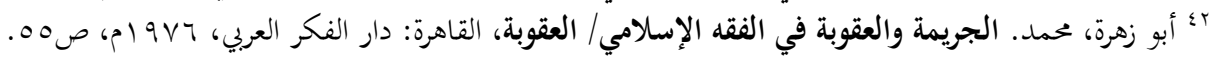




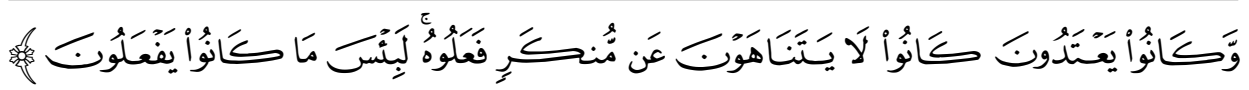

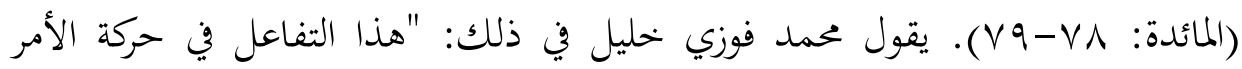

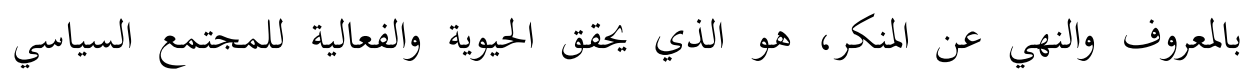

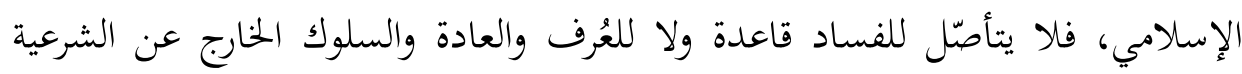

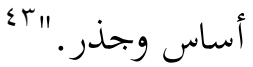

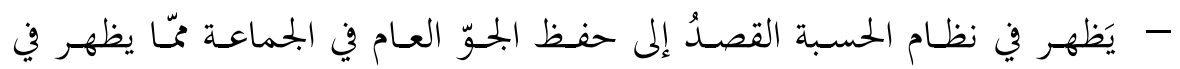

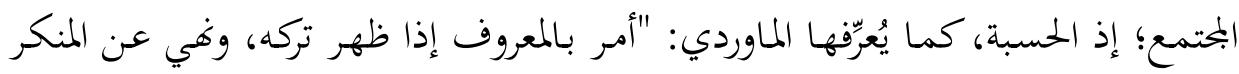

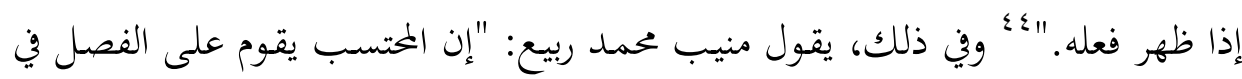

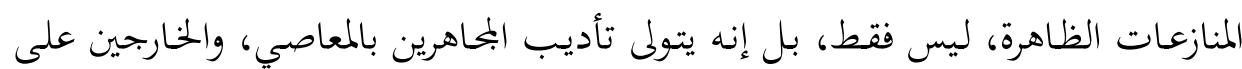

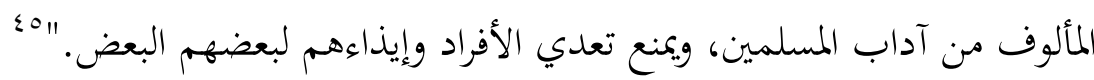

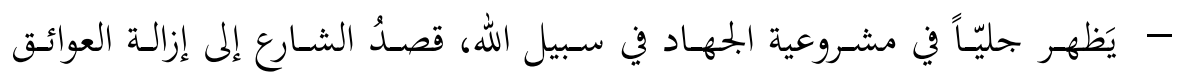

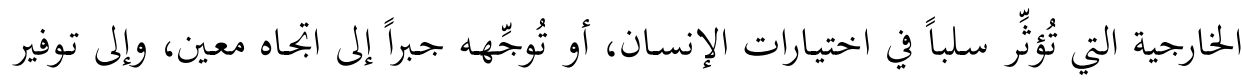

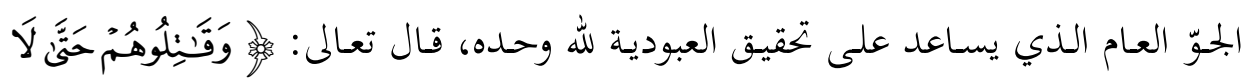

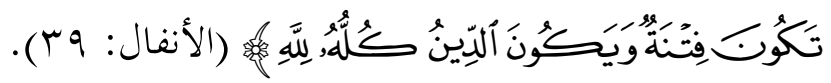

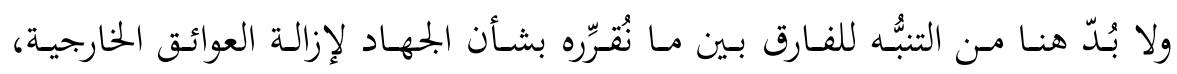

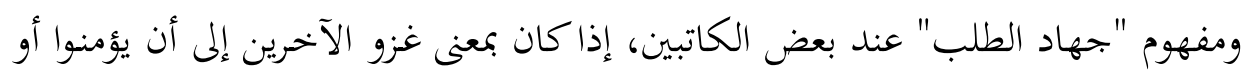

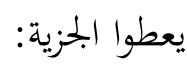

أولاً: نحن نقصد بالجهاد معنئ عامّاً يشمل الجهاد القتالي، والجهاد السلمي بالحكمة

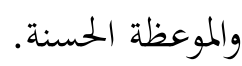

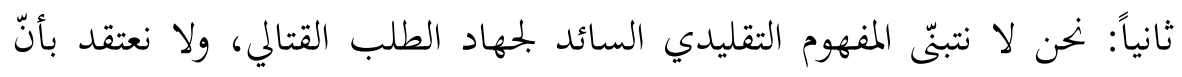

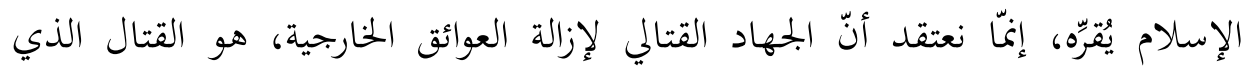

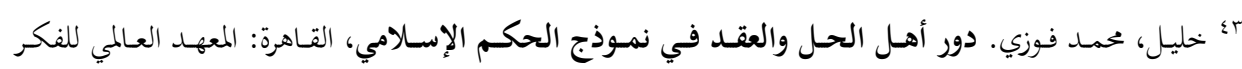

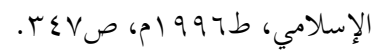
؛؛ الماوردي، علي بن محمد. الأحكام السلطانية والولايات الدينية، تحتيق: سمير مصطفى رباب، بروت: المكتبة

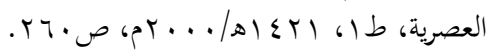
ه؛ ربيع، منيب عمد. ضمانات الحرية بين واقعية الإسلام وفلسفة الديمقراطية، الرياض: مكتبة المعارف، طا، .r.V.P( 


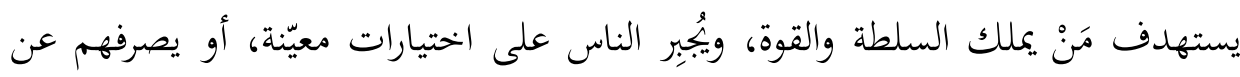

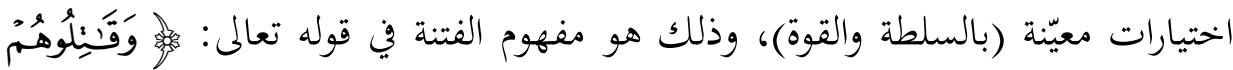

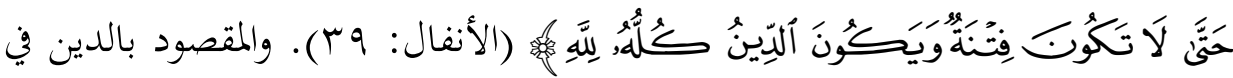

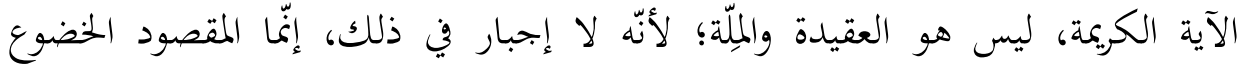

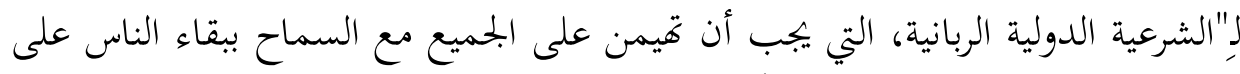

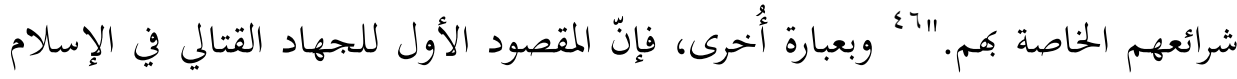

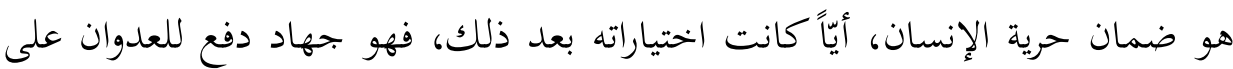
الحريات، وهو جهاد طلب لضمان تلك الحريات، حين يتم الاعتداء عليها بصورة

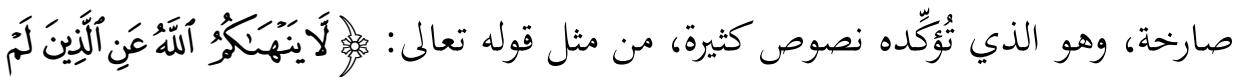

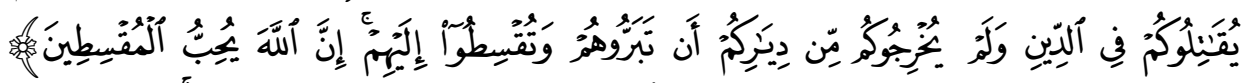

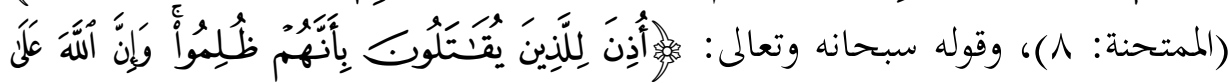

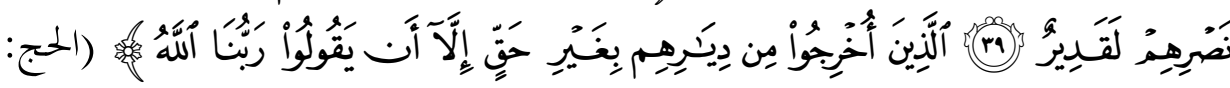

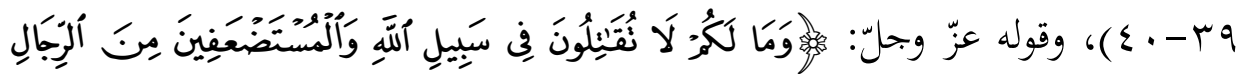

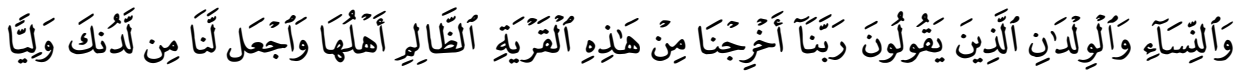

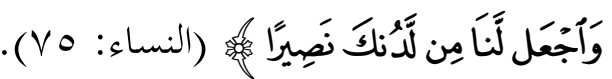

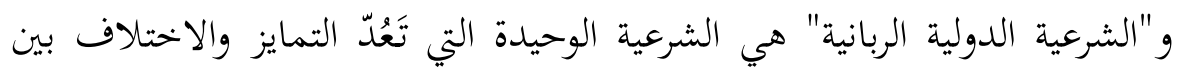

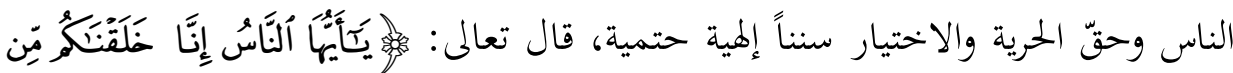

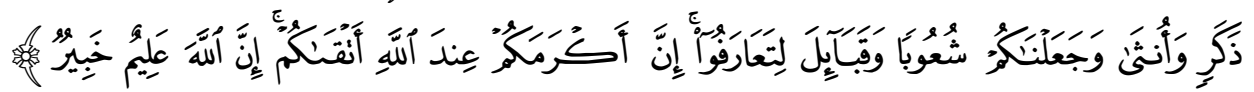

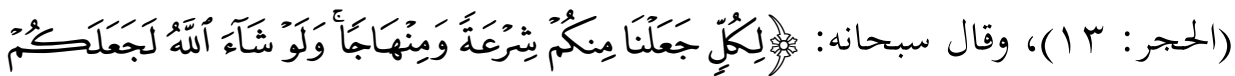

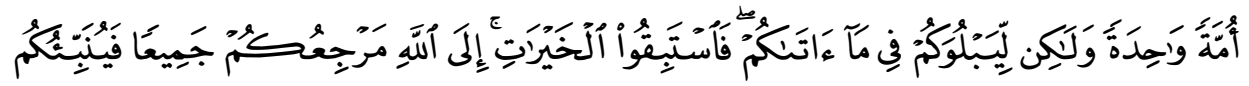

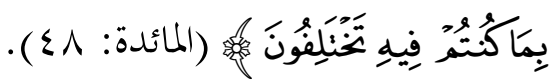

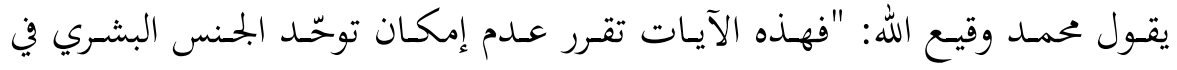

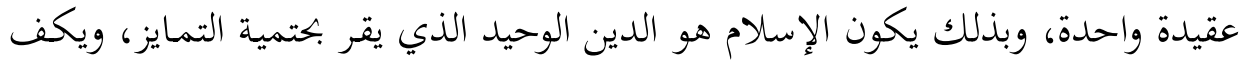
7" البيانوي،، حمد أبو الفتح. القواعد الشرعية ودورها في ترشيد العمل الإسلامي، قطر: وزارة الأوقاف والشؤون 
عن دعوى قسر البشر جميعهم على منهجه كما فعلت جميع الحضارات السالفة....، وما

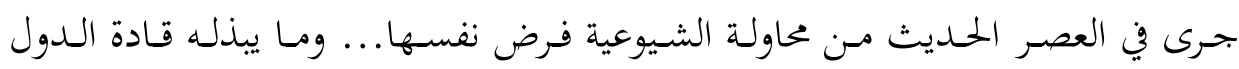

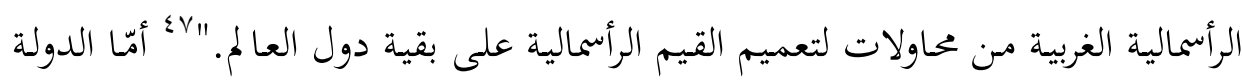

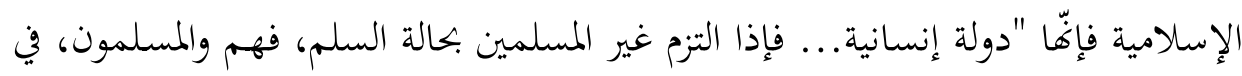

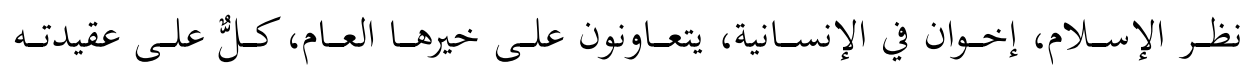

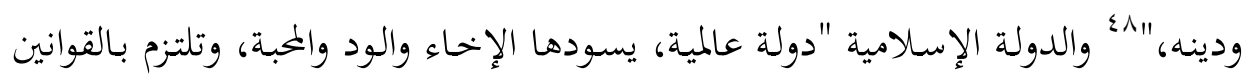

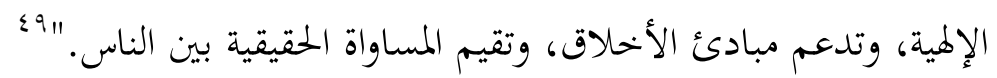

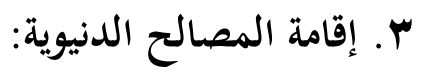

إنّ الإنسان، من حيث هو إنسان، كافراً كان أو مؤمناً، يحتاج، لاستمرار وجوده في

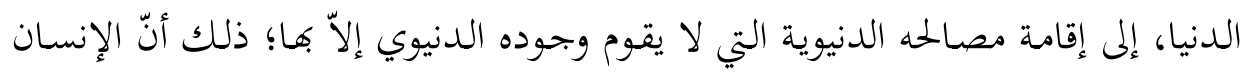

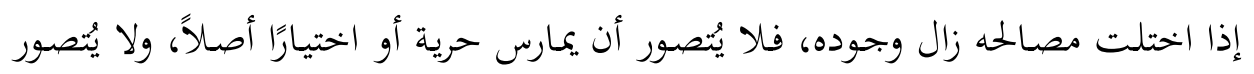

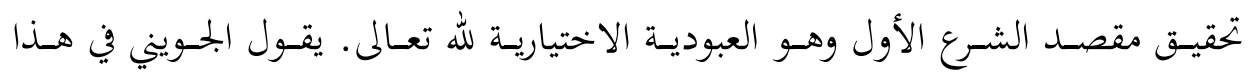

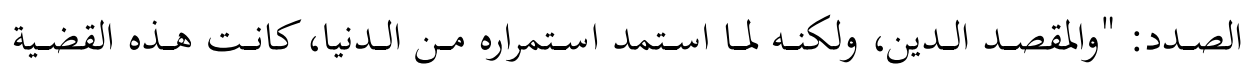

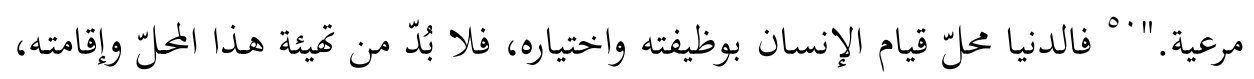
ليُمكن القيام بالوظيفة المطلوبة فيه. إنّ وجود إلزامات إجبارية هو أمر تستدعيه ضرورة الاجتماع الإنساني؛ لإقامة الحياة

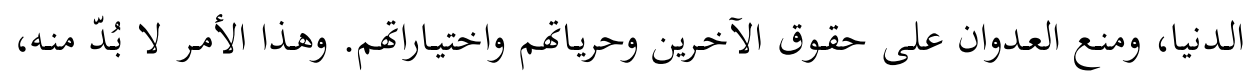

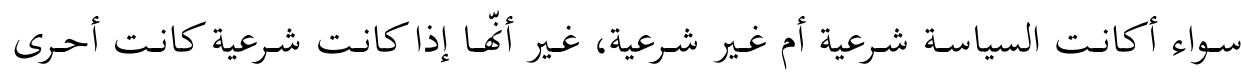

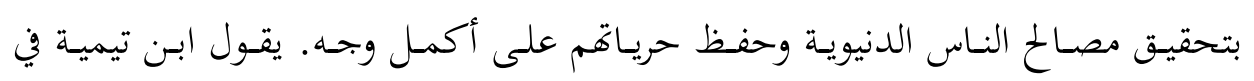

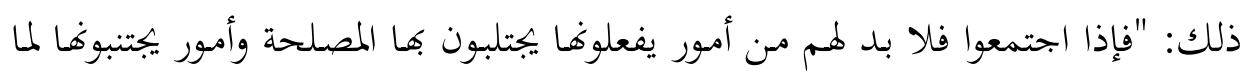

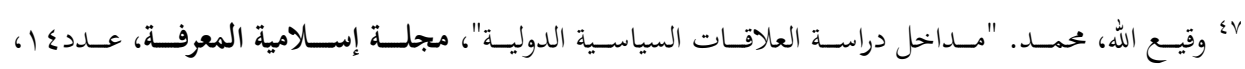

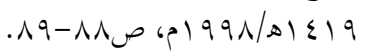

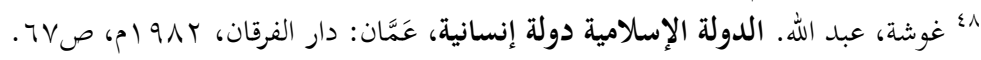

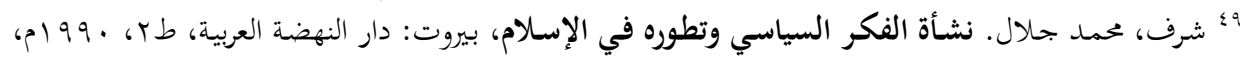

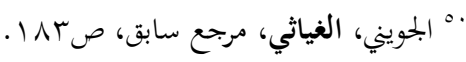


فيها مـن المفسـدة، ويكونون مطيعين للآمر بتلك المقاصد، والنـاهي عن تلك المفاسـد،

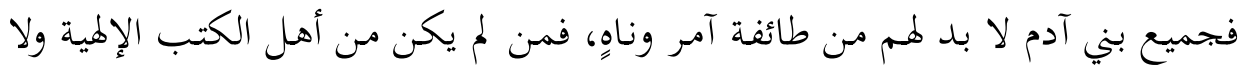

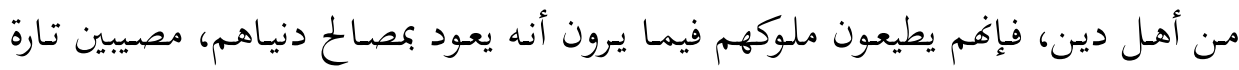

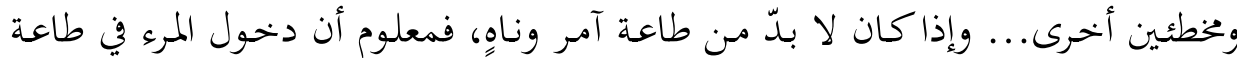

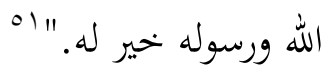

ويقول الشاطبي: "ما علم بالتجارب والعادات، من أن المصالح الدينية والدنيوية لا لهيرل تحصل مع الاسترسال في اتباع الهوى والمشي مع الأغراض، لما يلزم في ذلك من التهارج

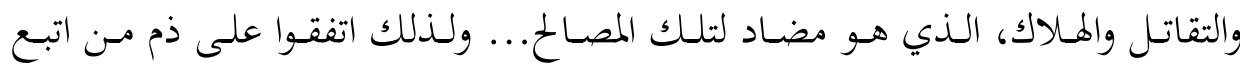
شهواته وسار حيث سارت به، حتى إن من تقدم ممن لا شريعة له يتبعها، أو كانت له شريعة درست، كانوا يقتضون المصالح الدنيوية بكف من اتبع هواه في النظر العقلي...

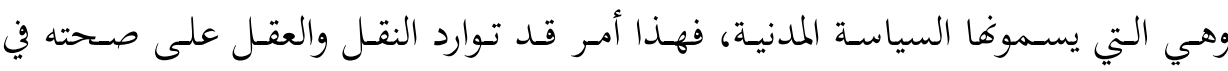

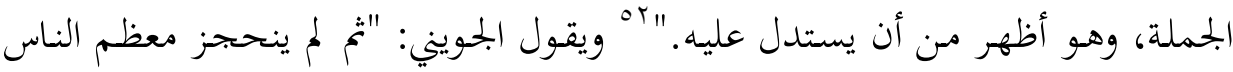

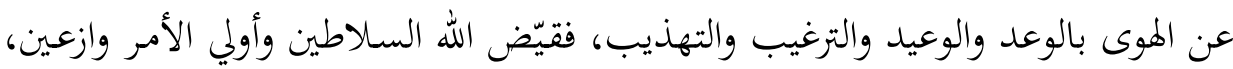

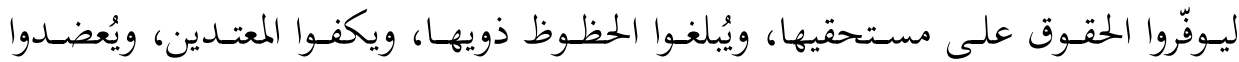

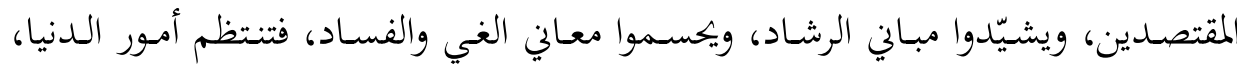

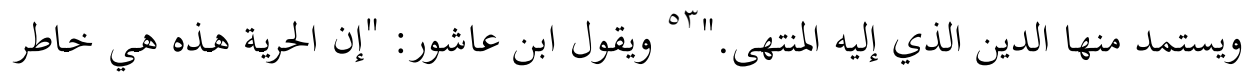
غريزي في النفوس البشرية، فيها نماءُ القوى الإنسانية من تفكير وقول وعمل، وبها تنطلق المواهـب العقلية متسـابقةً في ميـادين الابتكار والتدقيق. فلا يحتق لها أن تُسـام بقيد، إلا

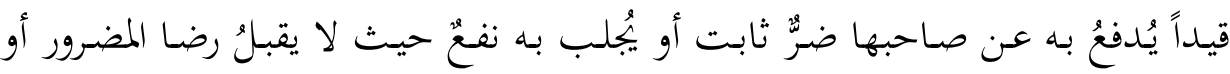

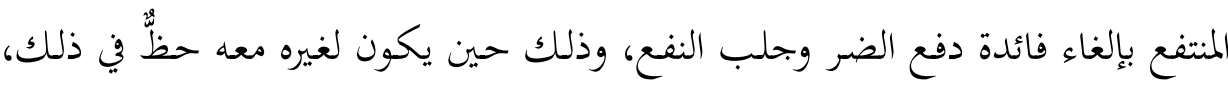

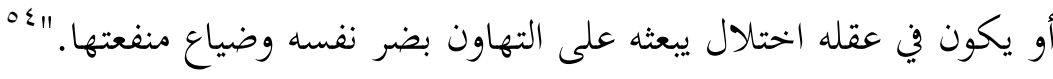
اه ابن تيمية، أحمد بن عبد الحليم. الحسبة في الإسلام، تحقيق: سيد بن محمد بن أبي سعدة، الكويت: مكتبة دار

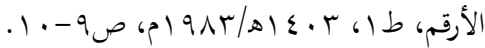

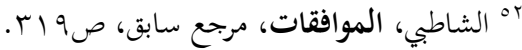

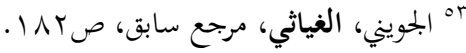

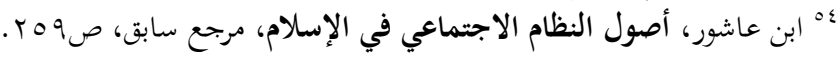


ووظيفـة السياسـة الشـرعية هي العمـل على إيبـاد هـذه المصـالح، وبتعبـير الشـاطبي

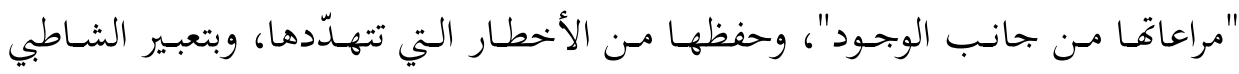

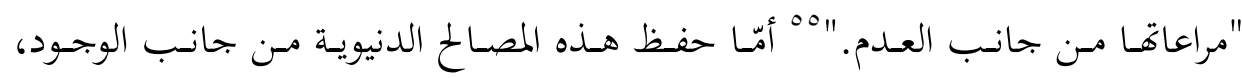

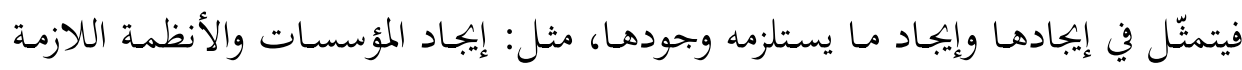

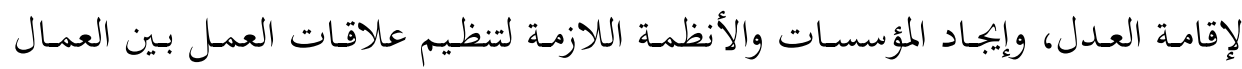

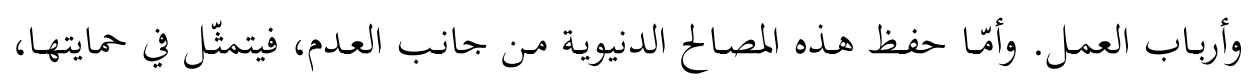

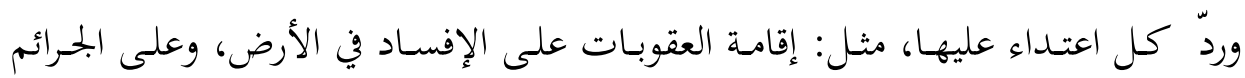

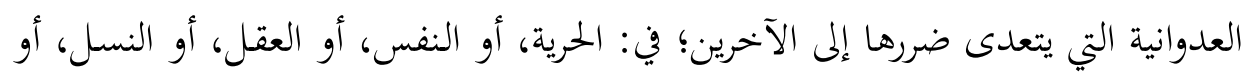
المال. والسياسـة الشـرعية مطالبـة بإقامـة مصـالح الإنسـان الدنيويـة، بغض النظر عـن ديـن

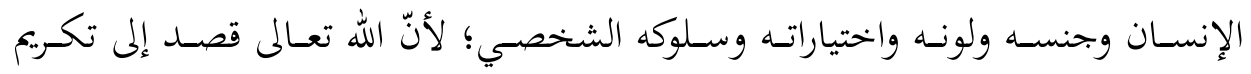

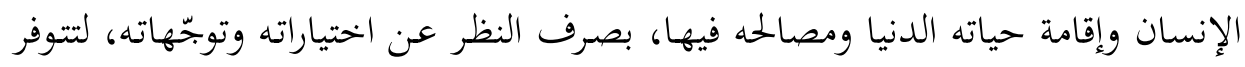

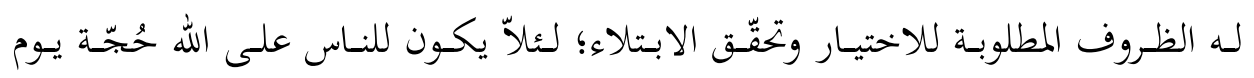
القيامة.

لقد قرّر الإسلام المساواة بين الناس من دون تمييز بينهم بلون أو جنس أو دين أو

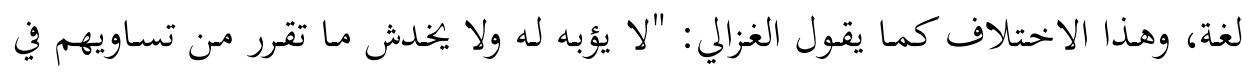

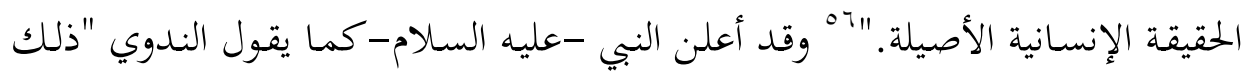

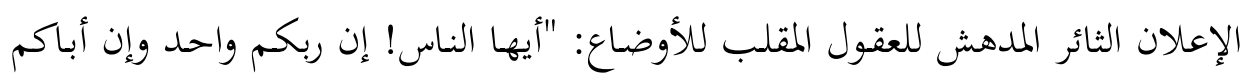

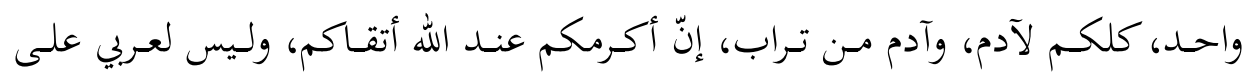

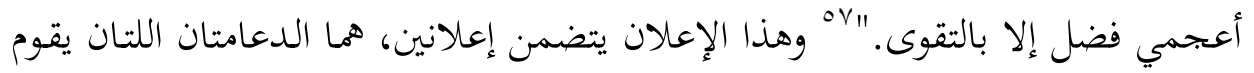

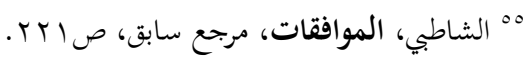

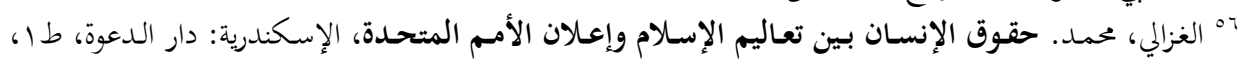

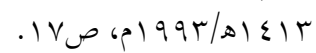

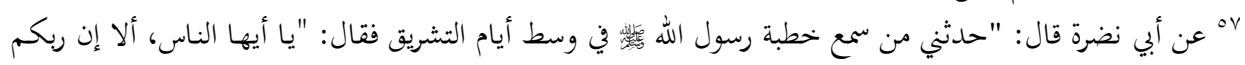

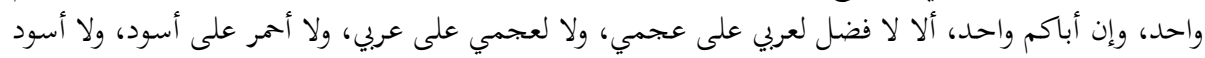

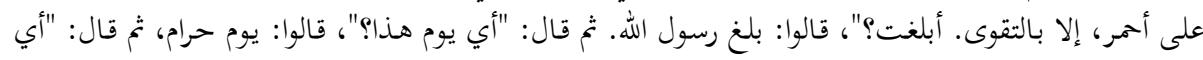

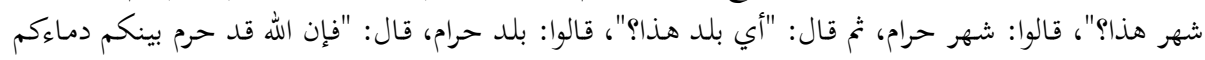


عليهما الأمن والسلام، وعليهما قام السلام في كل مكان وزمان: وحدة الربوبية، والوحدة

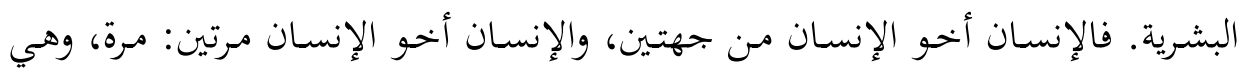

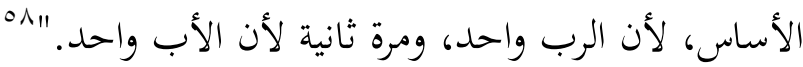
ومـن الأمثلة على وظائف السياسة الشرعية، متّا ظـاهره الإجبار وحقيقته الالتزام

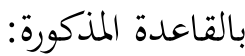

- إقامة بعض العقوبات والحدود، وقتال مَنْ يُهلِّد أمن الجماعة أو حياة أفرادها أو

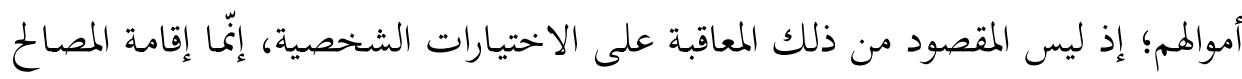

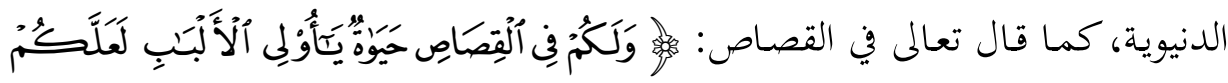

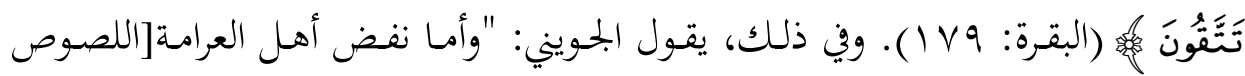

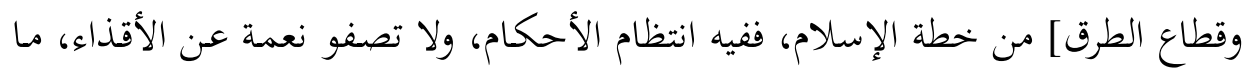

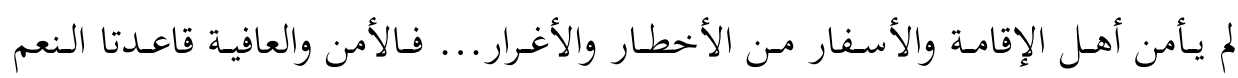

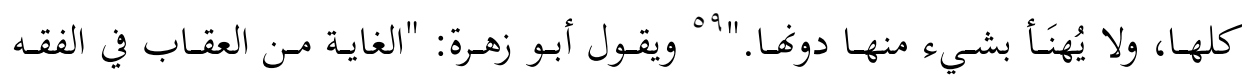

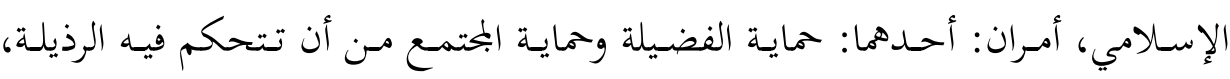

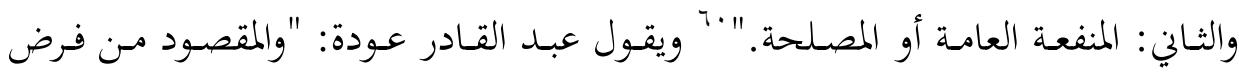

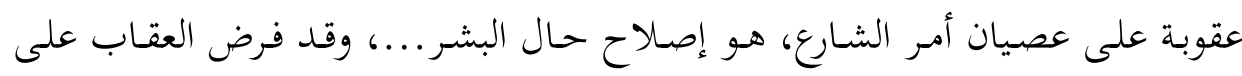

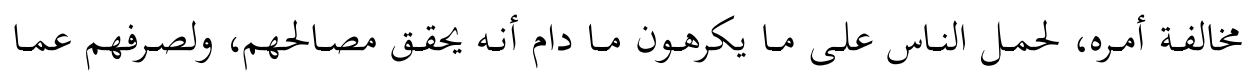

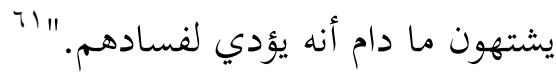

وأموالكم"--قال: ولا أدري قال: أو أعراضكم، أم لا-كحرمة يومكم هذا، في شهركم هـذا، في بلدكم هذا.

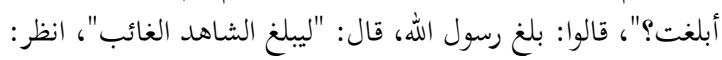

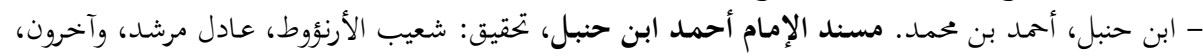

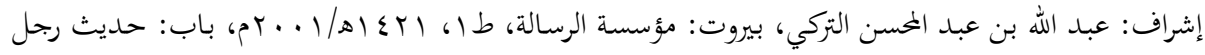

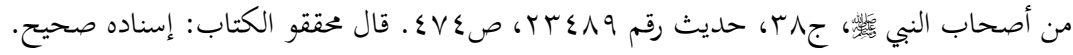

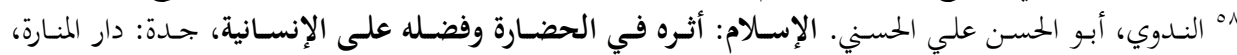

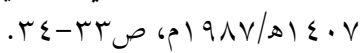

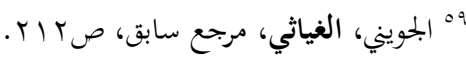

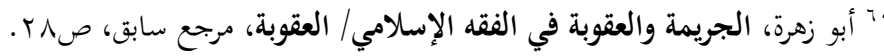

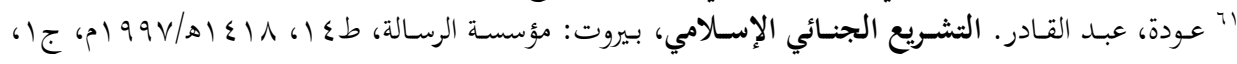


- مـن أهـم وظائف السياسة الشرعية إقامـة العـل بـين الناس، كل النـاس مـن دون

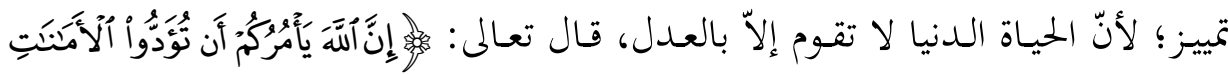

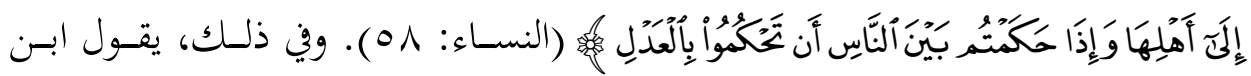

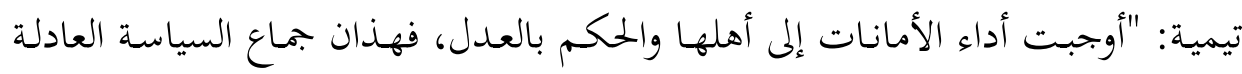

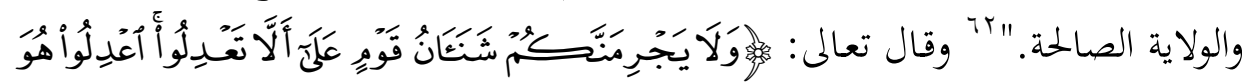

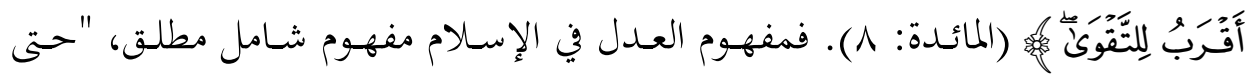

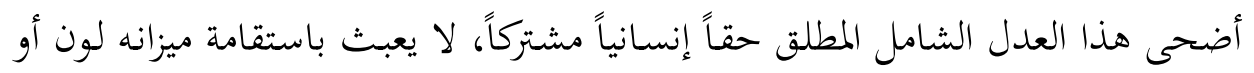

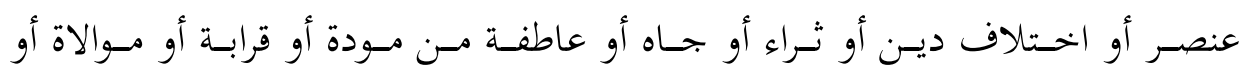
عداء.

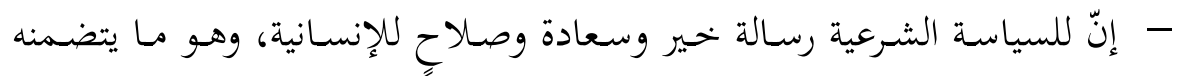

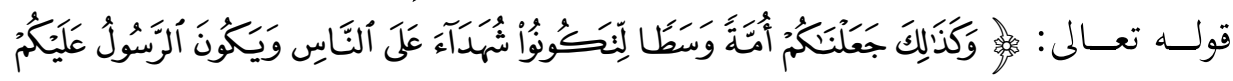

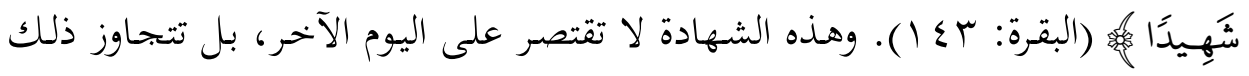
إلى معنى الشهادة على الناس في الدنيا. ومقتضى هذه الشهادة أن تكون الأمة الإسلامية

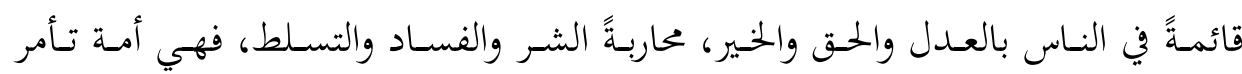

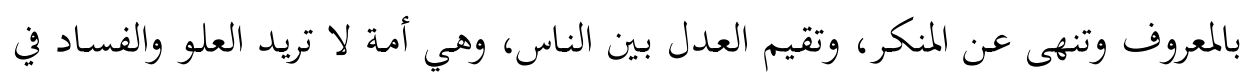

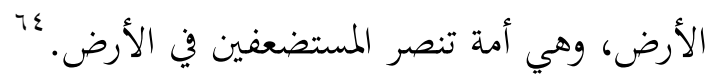

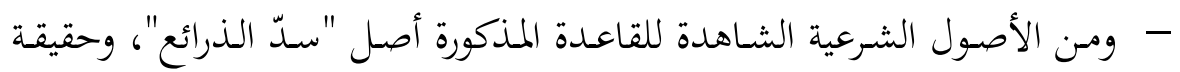

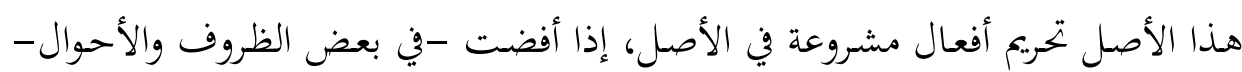
إلى مفاسد. وهذا الأصل وإن كان في ظاهره تقييدًا للحرية في فعل المباح أحيانًا، إلاّ أنّه

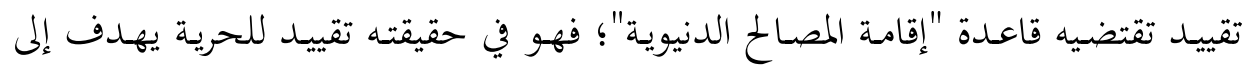

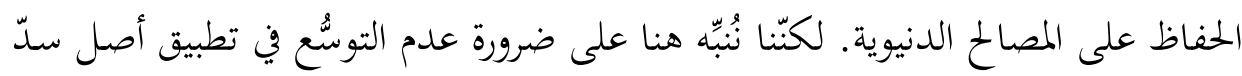

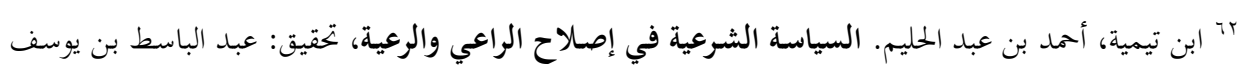

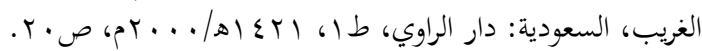

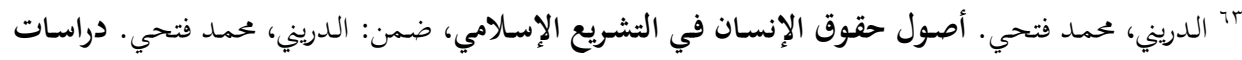

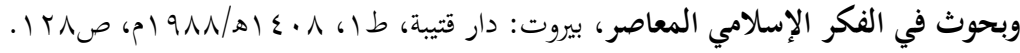

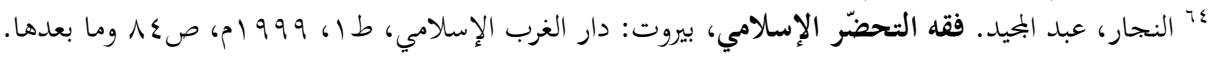




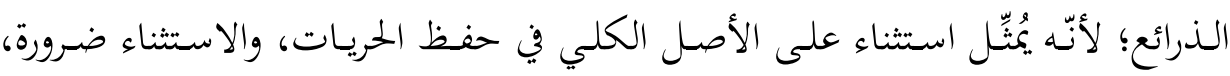

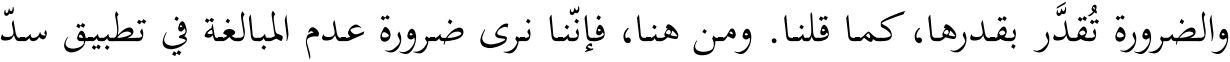

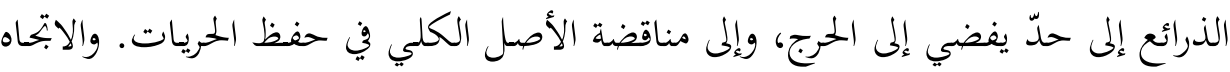

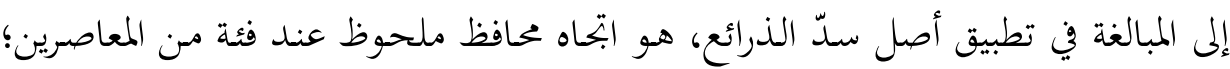

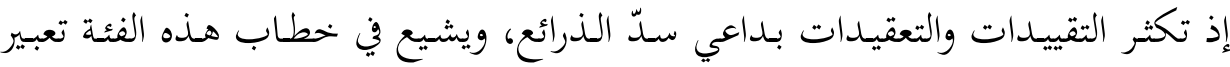

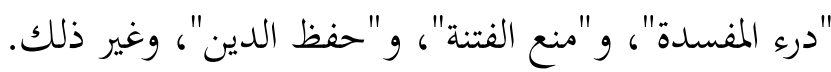

\section{ع. تقليل الإلزامات الإجبارية:}

إنّ مقصد السياسة الشرعية الأول هو رعاية حرية الإنسان، وتركه واختياراته من دون

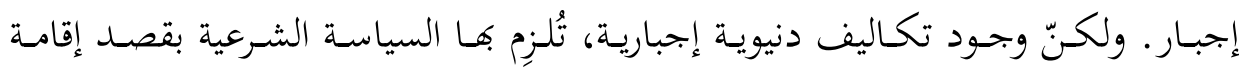

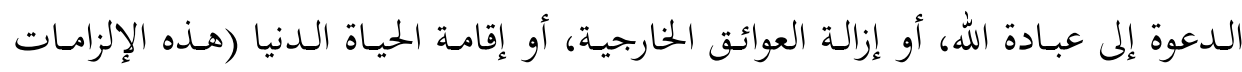

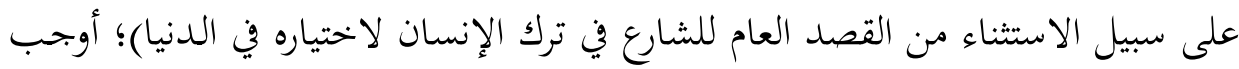

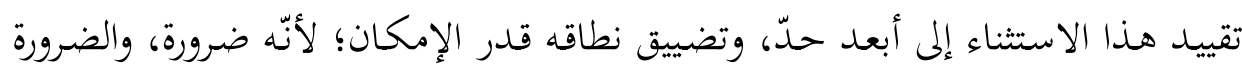

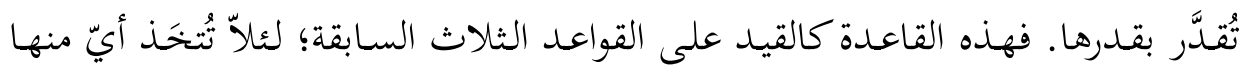

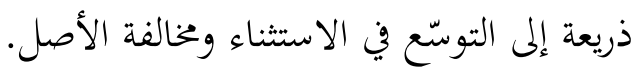
أمّا وظيفة السياسة الشرعية فهي العمل في إطار هذه القاعدة، والسعي إلى تحقيقها، وجعلها مقصدًا لما في تصرفاتا حيال الرعية. ومن الأمثلة المقرّرة لمذه القاعدة: - قصد الشارع إلى حصر دائرة الإلزامات الدينية الإجبارية، وتضييق نطاقها،

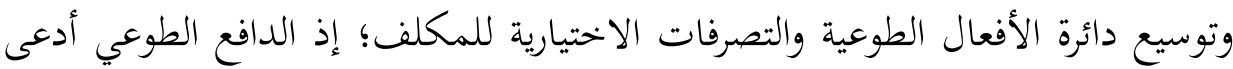

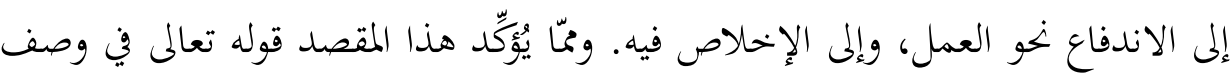

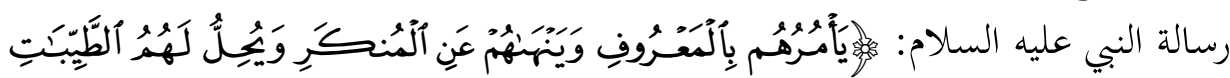

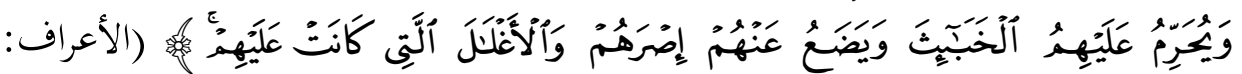

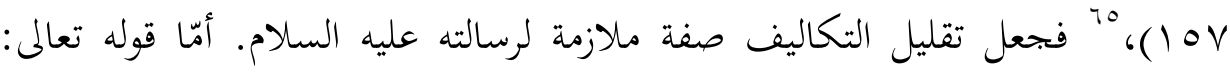

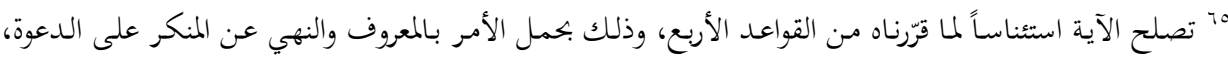

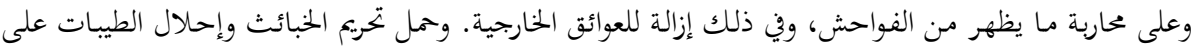
تحقيق مصالح الدنيا. وحمل وضع الإصر والأغلال على تقليل الإلزامات الإجبارية. 


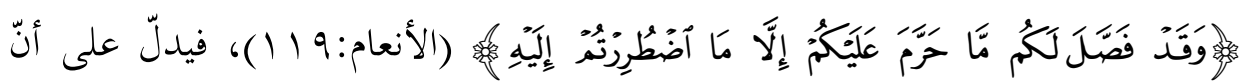

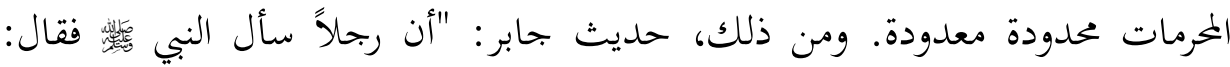

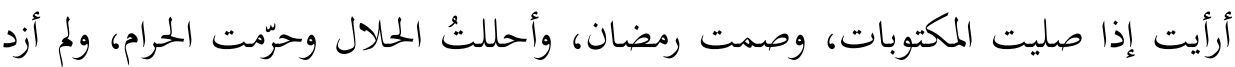

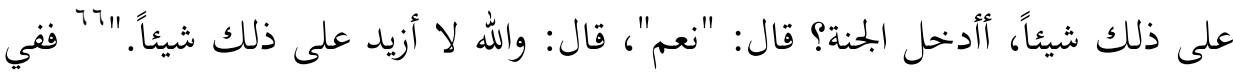

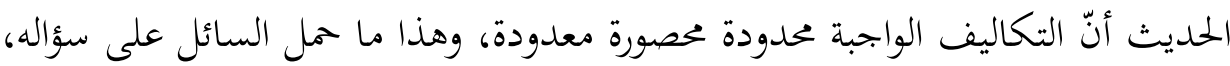

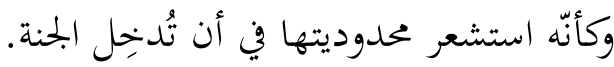

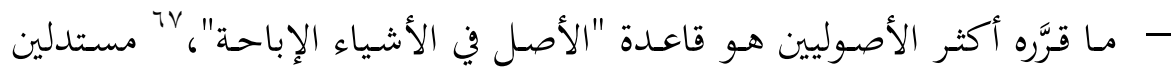

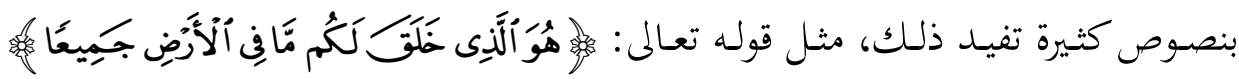

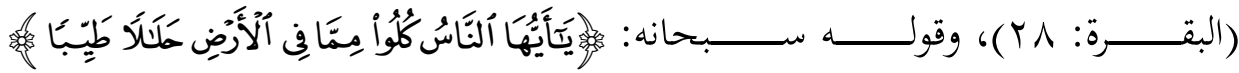

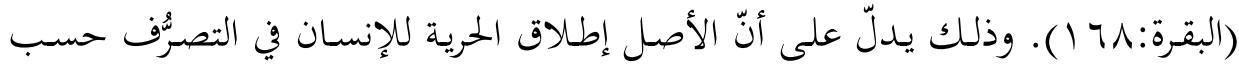

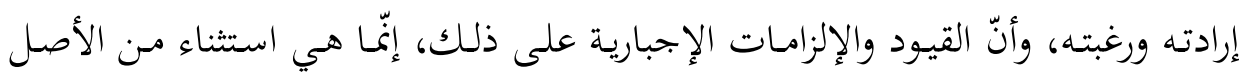
العام، والاستثناء يُضَيَّق نطاقه إلى أبعد حدّ كما قرَّرَّنا.

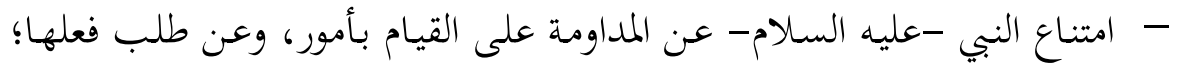

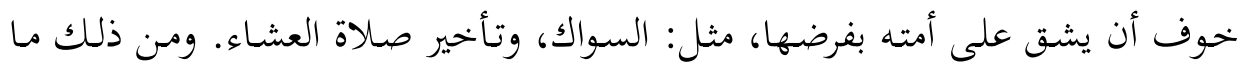

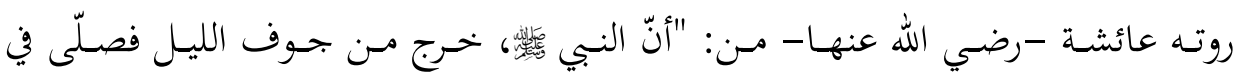

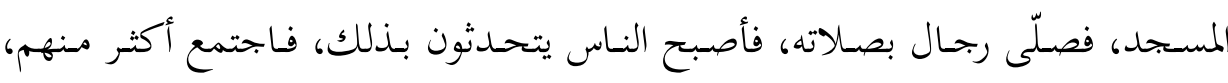

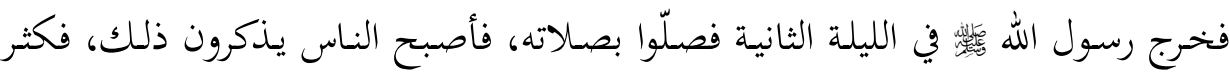

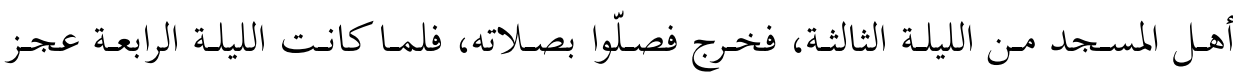

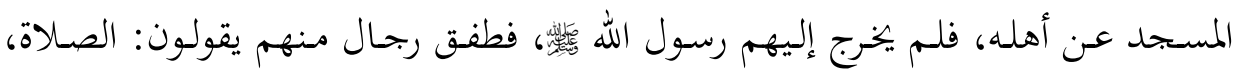

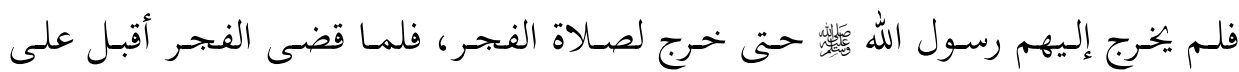

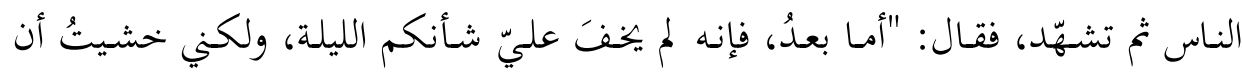

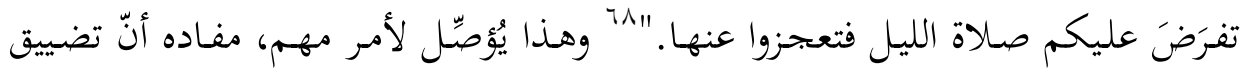

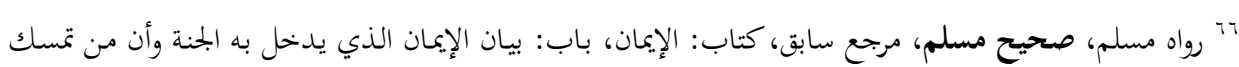

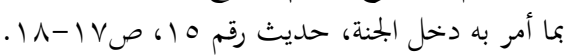

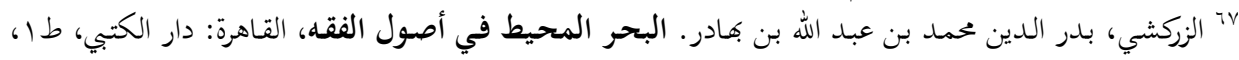

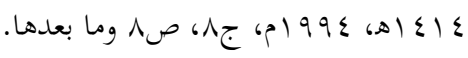
1، رواه البخاري، صحيح البخاري، مربع سابق، كتاب: صلاة التزويح، باب: فضل من قام في رمضان، حديث رقم 


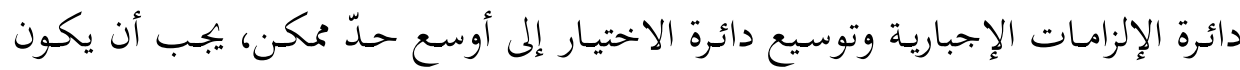

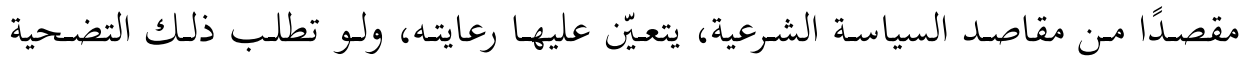

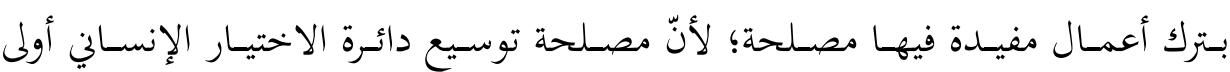
بالاعتبار والتقلديم. - - محاربـة السياسـة الشـرعية الابتــاع في الــدين، وسـعيها إلى منـع نشـر البـدع في

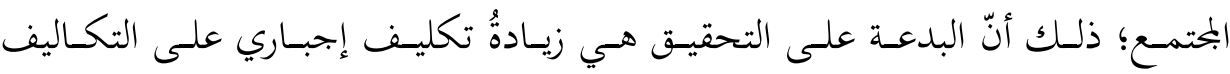

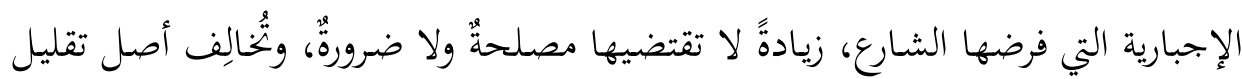
الإلزامات الإجبارية.

- مـ الأمور التي تتفق ومقتضى قاعدة تقليل الإلزامات الإجبارية، نأي السياسة

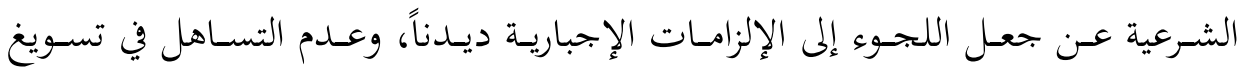

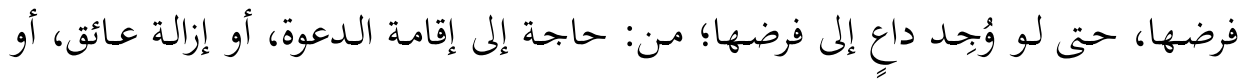

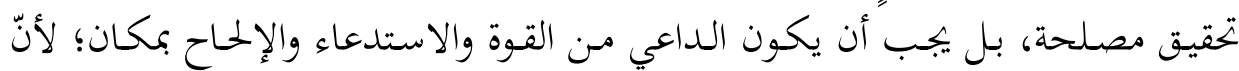
مثل هذا الإلزام مخالف لمقصد السياسة الشرعية الأول (رعاية حرية الإنسان وتوسيع دائرة

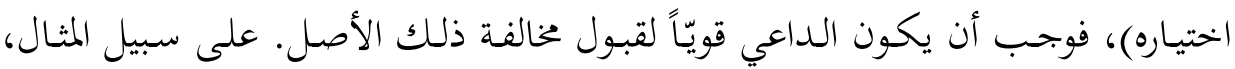

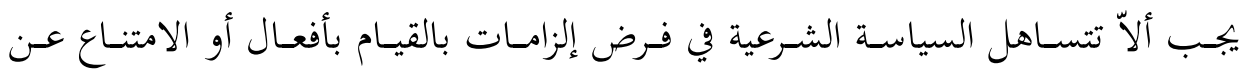

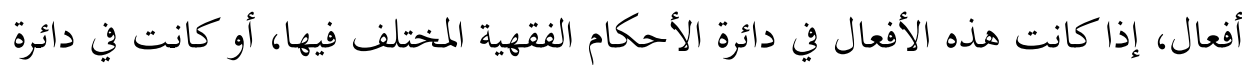
الأفعال المندوب فعلها، أو المكروه فعلها.

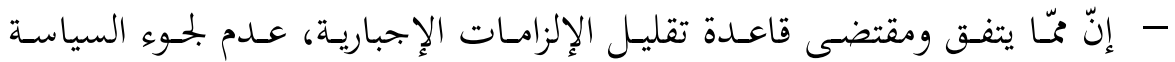

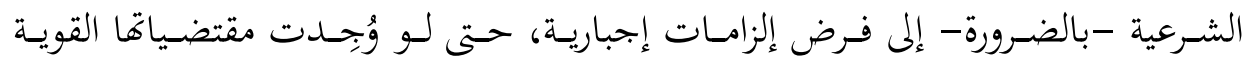

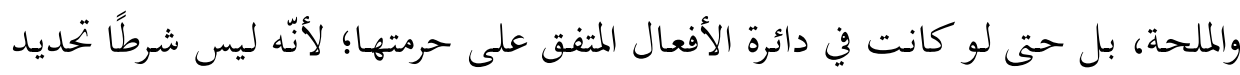

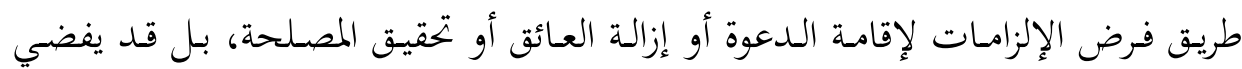

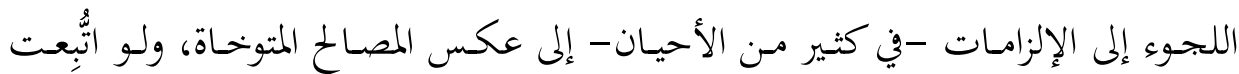

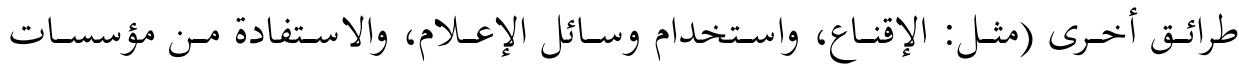

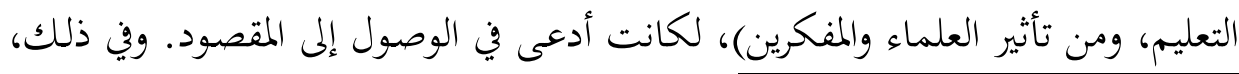
- مسلم، صحيح مسلم، مرجع سابق، كتاب: صلاة المسافرين وقصرها، باب: الترغيب في قيام رمضان، حديث 


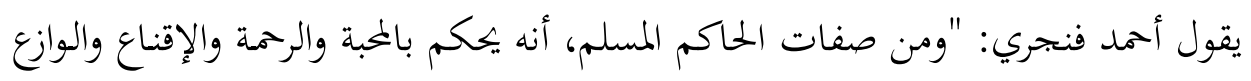

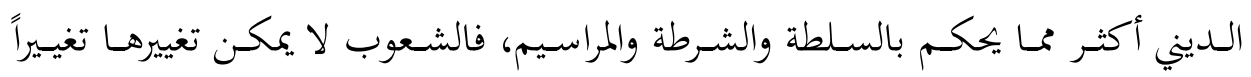

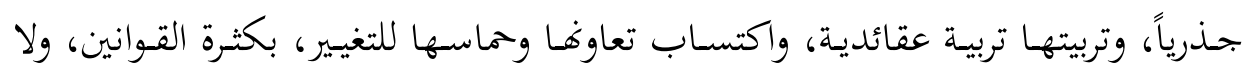

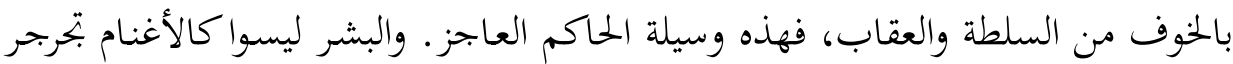

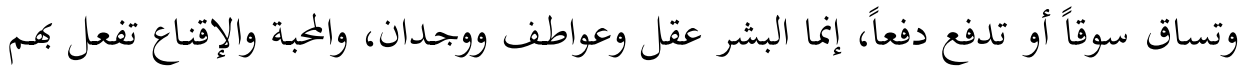

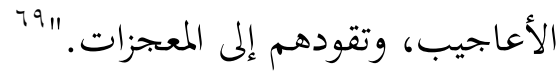

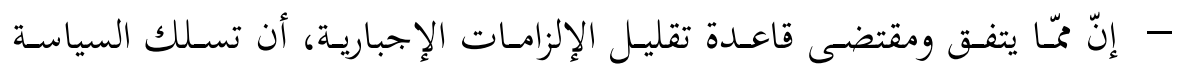

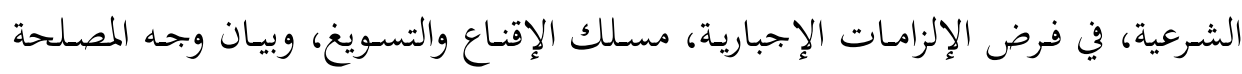

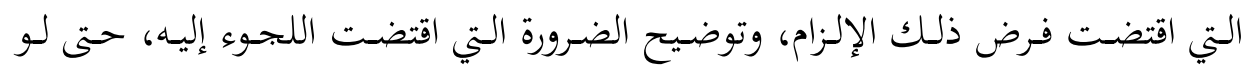

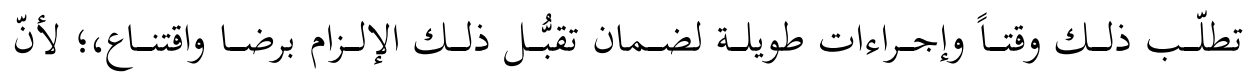

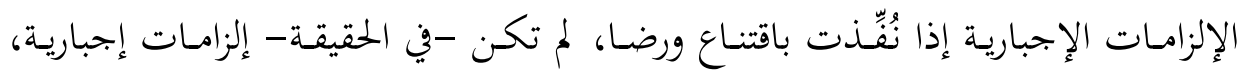

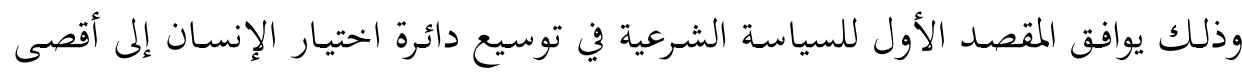

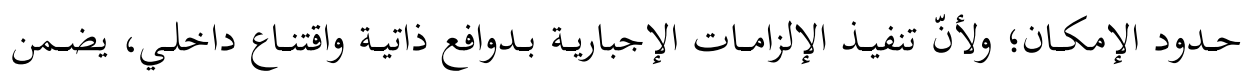

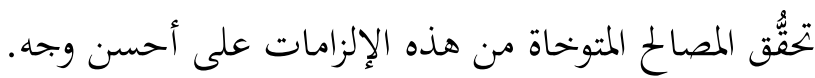

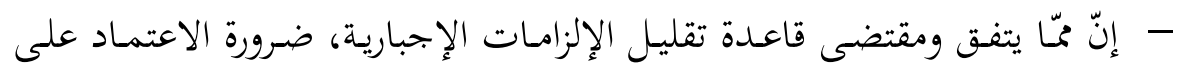

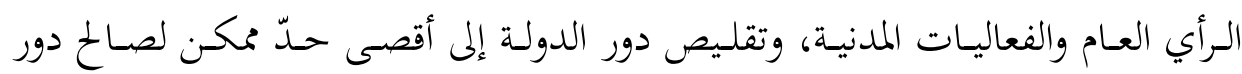

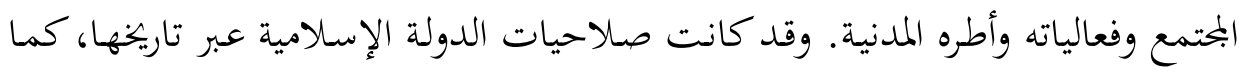

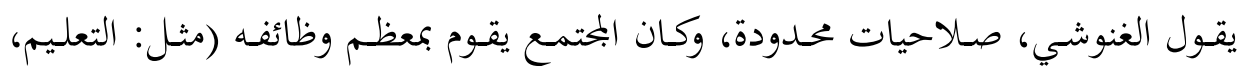

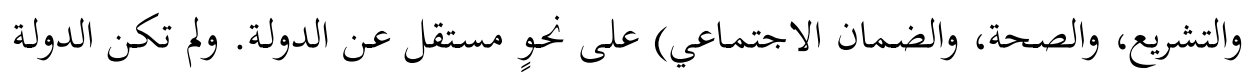

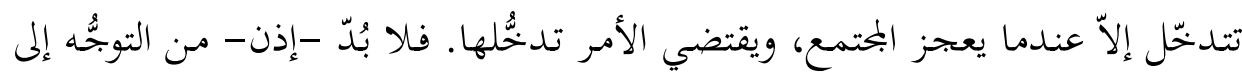

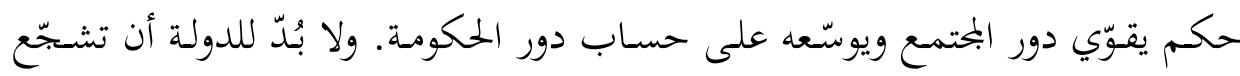

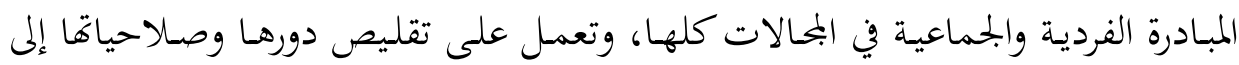

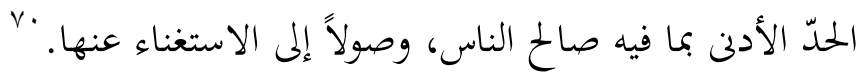

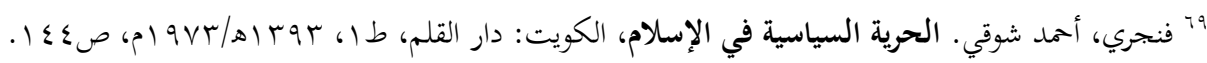

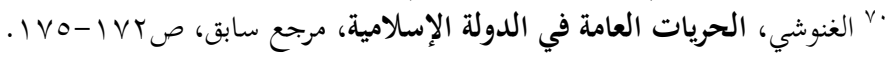




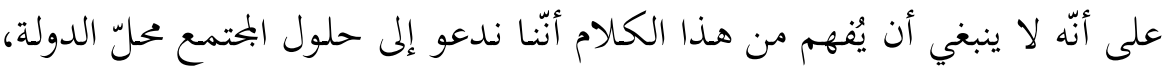

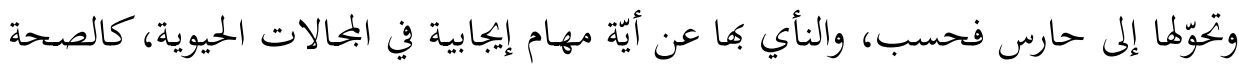

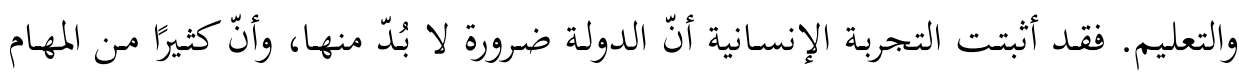

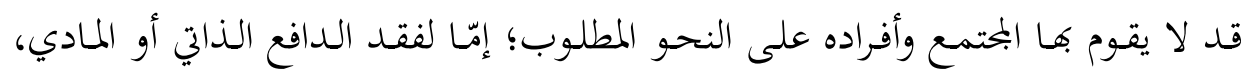

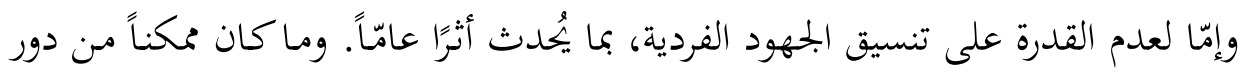

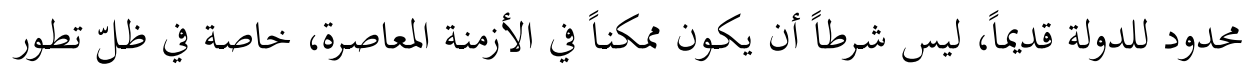

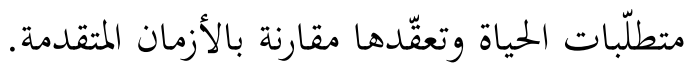

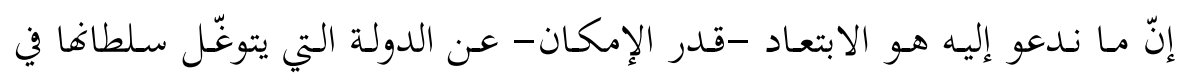

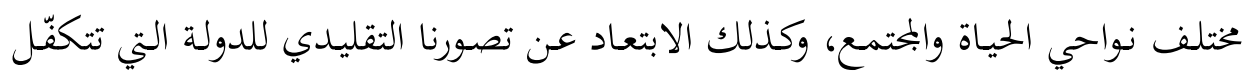

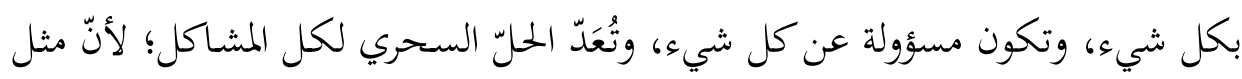

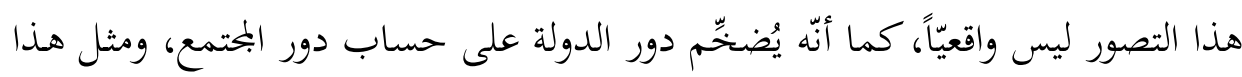

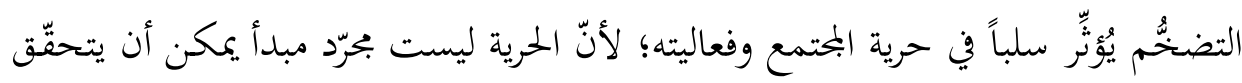

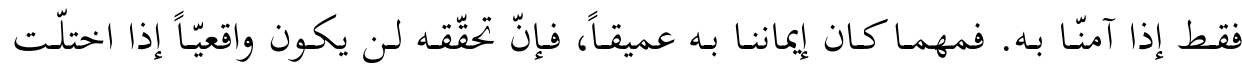

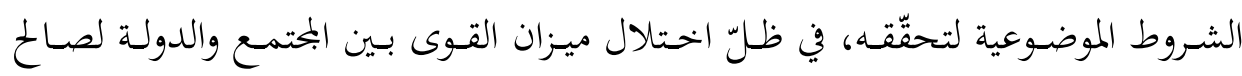

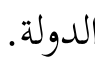

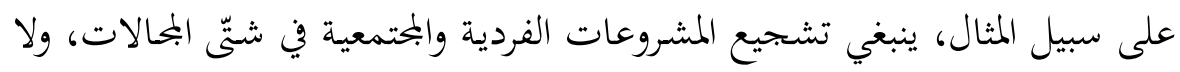

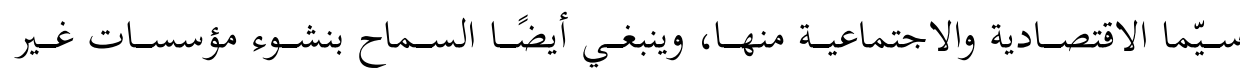

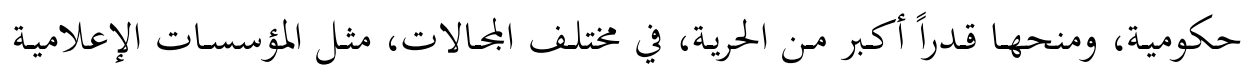

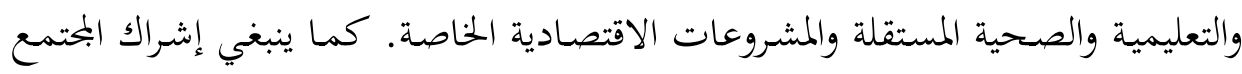

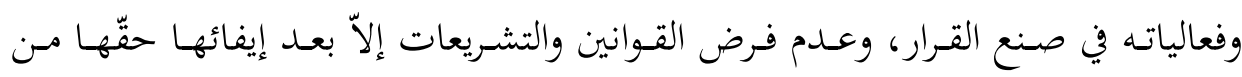
المناقشة عبر الأطر الاجتماعية المختلفة، واتخاذ قرار عام بشأنها.

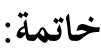

إذا كانت الحرية واحدة من قضايا عديدة شغلت الإنسان في كل عصر، فإنّا تُعَدّ ألَّا

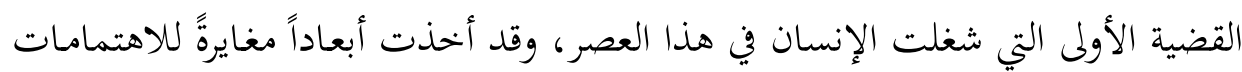




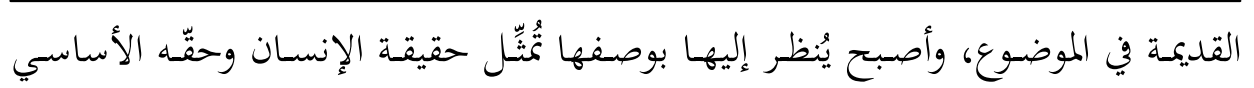
الأول.

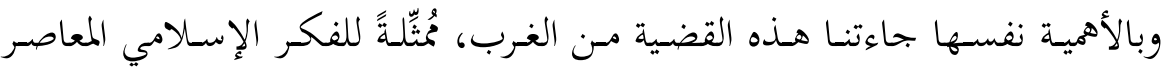

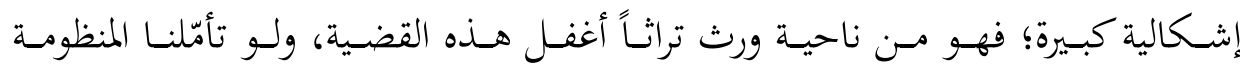

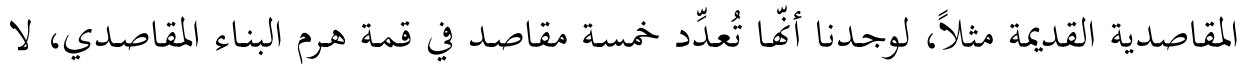

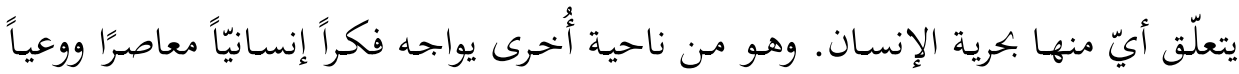

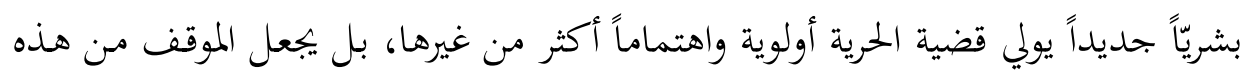
القضية معياراً للتمييز بين الحداثة والتخلُّف قدئ.

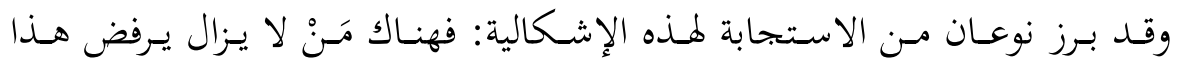

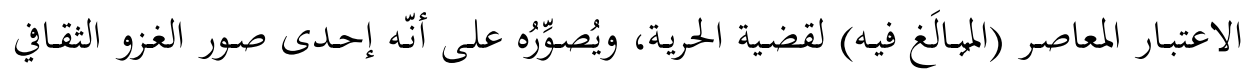

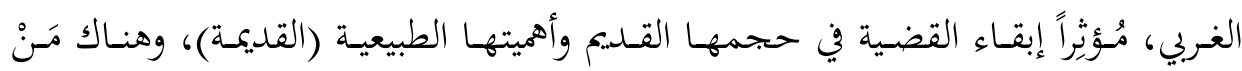
يجاول -ولو بصعوبة- إفساح مكان لما في المنظومة المقاصدية القديمة، وهؤلاء مثل مَنْ يحاول أن يفسح في مكان مكتظٍ موضعًا -وولو صغيرًا- لشيء كبير فاجأه، فتارة يكون

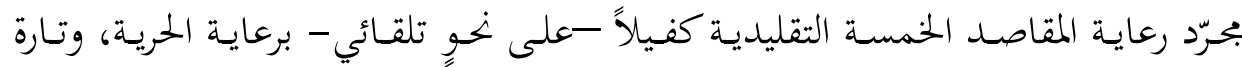

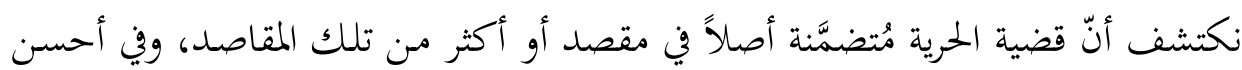

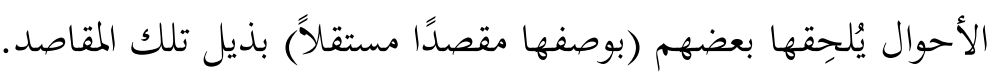

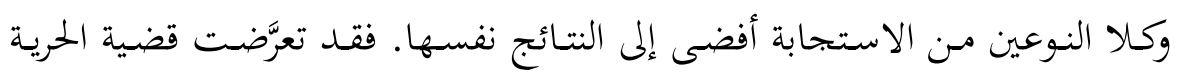

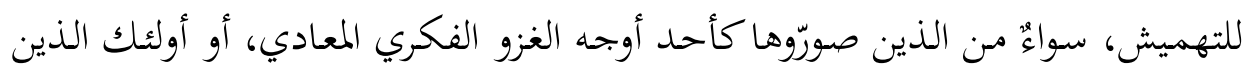

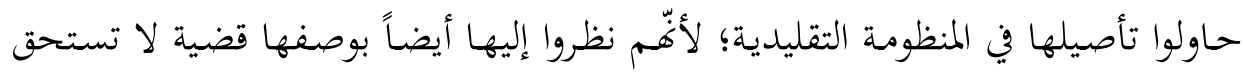

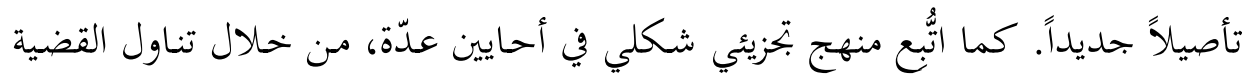

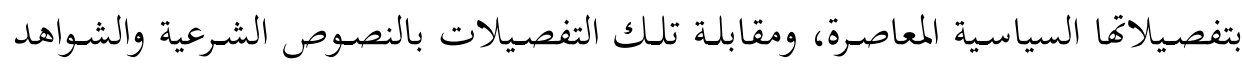
الدينية، دون محاولة إنشاء تصور إسلامي أصيل.

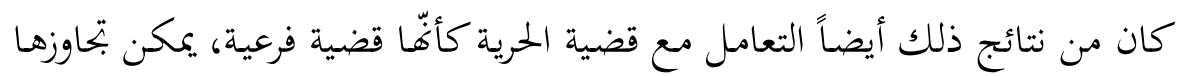

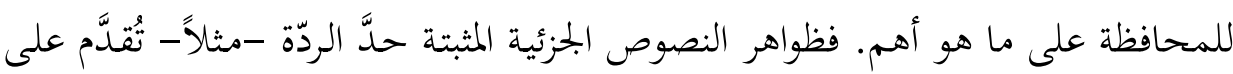

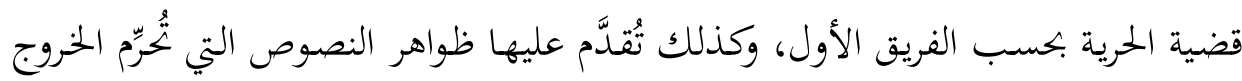




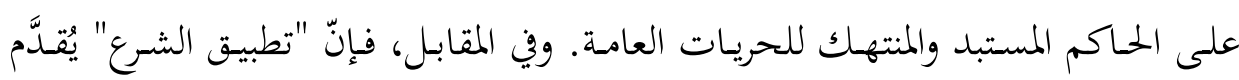

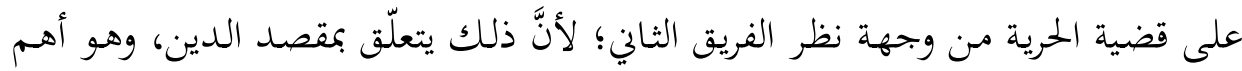

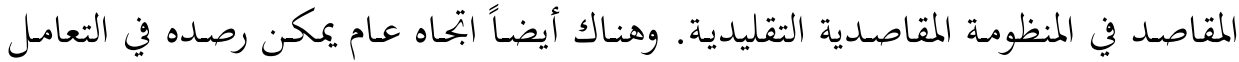

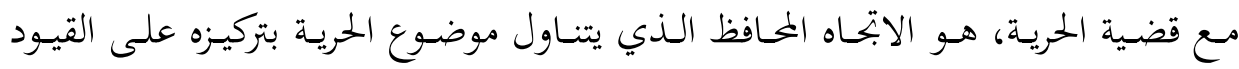

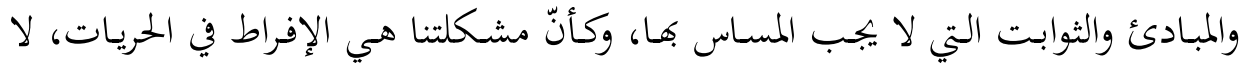

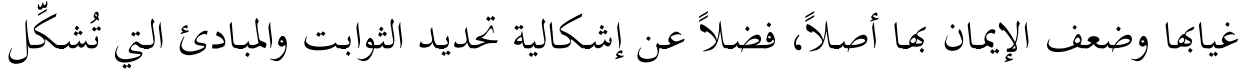

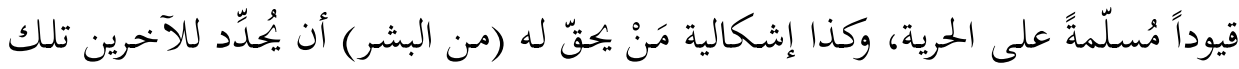

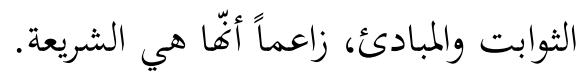

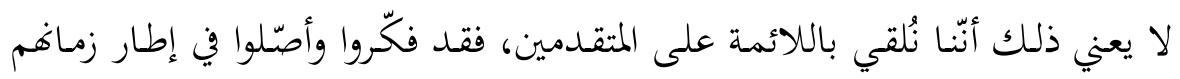

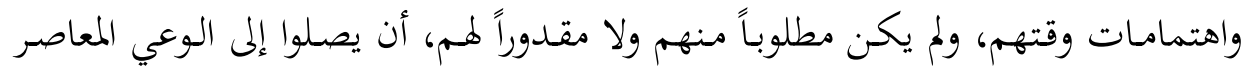

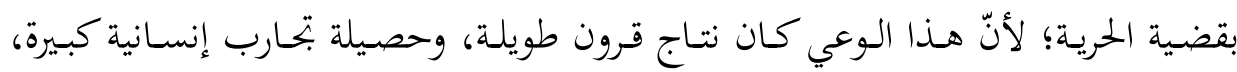

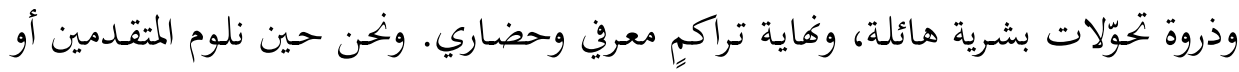

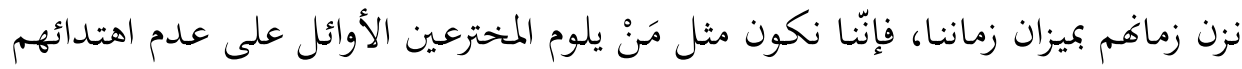

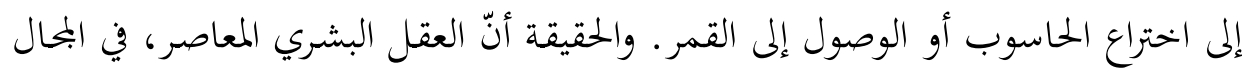

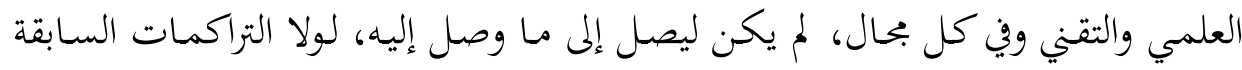
وجهود المتقدمين في ذلك المحال. حاول هذا البحث أن يُقدِّم إسهاماً متواضعاً في إعادة اكتشاف مركزية قضية الحرية

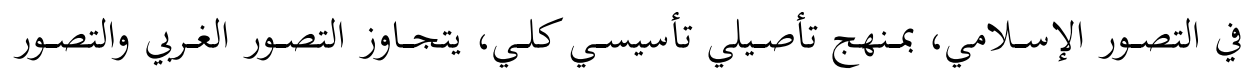

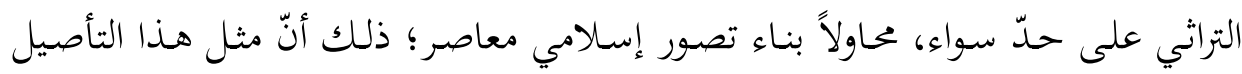

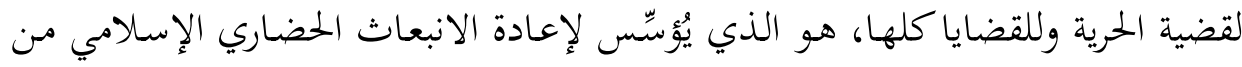

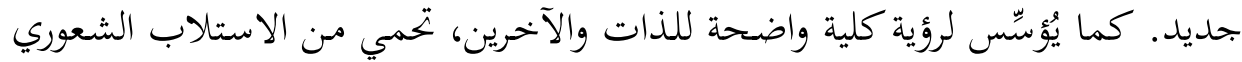

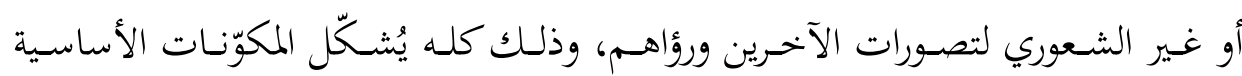
لإببداع والتميّز الحضاريين.

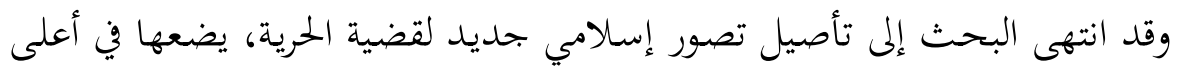

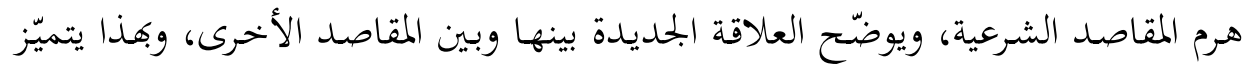


التصور الجديد عن التصور التراثي القديم للموضوع. كما يتميّز عن التصور الغربي في أنّه يُفسح بحالاً مهمّاً في أعلى الهرم المقاصدي أيضاً لقضية عبادة الله، وهي قضية غائبة تماماً

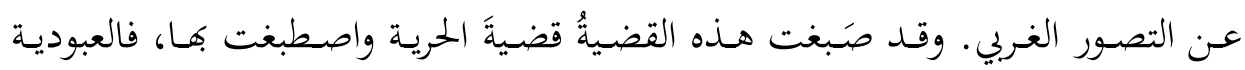

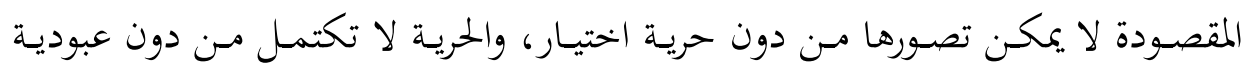

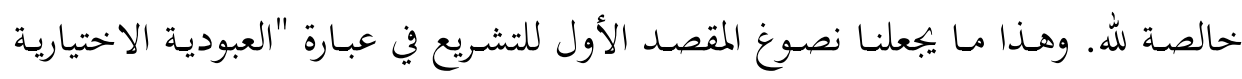
. لّ

وبالمثل، فقــ حـاول البحـث تأصسيل موضـوع الحريـة في السياسـة الشـرعية، وتأسيس قواعد كلية تحكمه. فالبُعْد السياسي الشرعي هو أحد الأبعاد المهمة لقضية الحرية، الذي لئي يستدعي التأصيل، وإعادة الكتابة فيه بعمق. أمّا أبرز ما خلص إليه البحث هو أنّ الوظيفة الأساسية للسياسة الشرعية ومقصدها

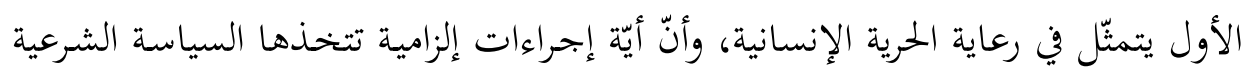

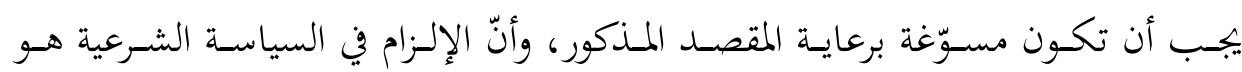

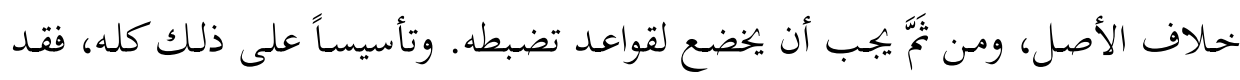

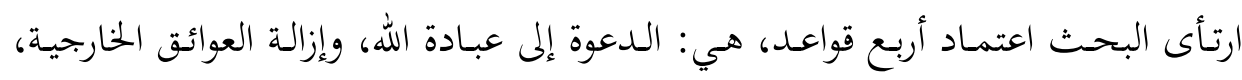
وإقامة المصالح الدنيوية، وتقليل الإلزامات الإجبارية.

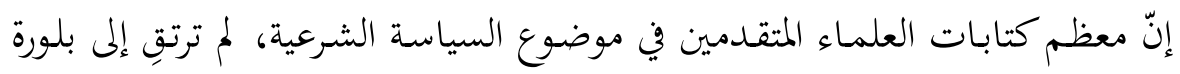
"علم في السياسة الشرعية"، يبحثث في قواعد القيام بشؤون الناس وَفق مقاصد الشرع. فلم يكن الاتحاه العام معنيّ بتأصيل قواعد تحكم ذلك، باستثناء محاولات قليلة.

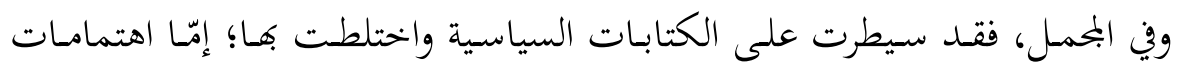
تاريخية فرعية مثل الإمامـة وشروط الإمـام ومواصفاته وحقوقه وواجباته، وإمّا اهتمامـات

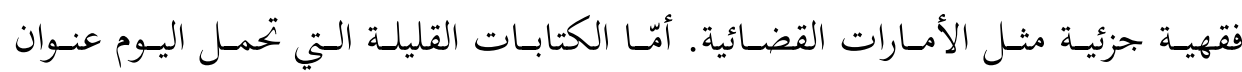

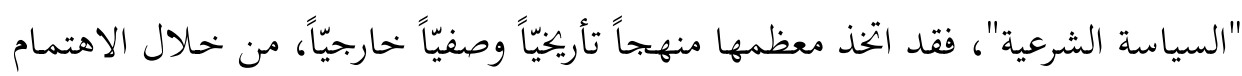
بدراسة تطور مصطلح "السياسة الشرعية" ودلالاته وروّاده وموضوعاته التاريخية، من دون

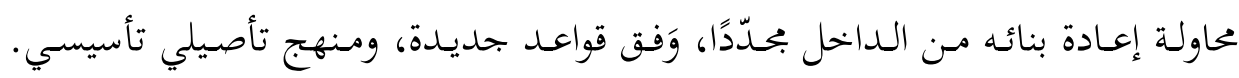


وبالمثل، فإنّ بعض الكتابات التي حاولت الحهوض في قضايا السياسة الشرعية، أعـادت اجترار القضايا القديمة، وبالأسلوب القديم نفسه.

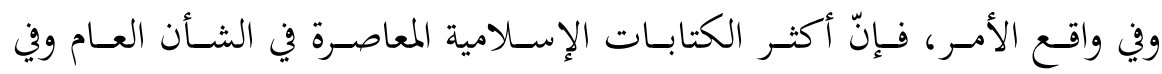

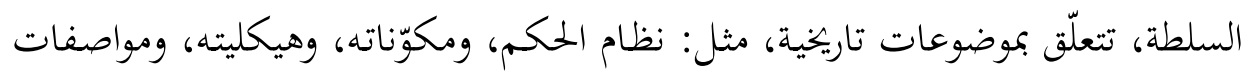

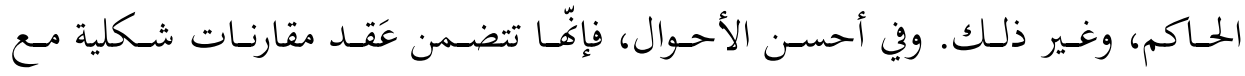

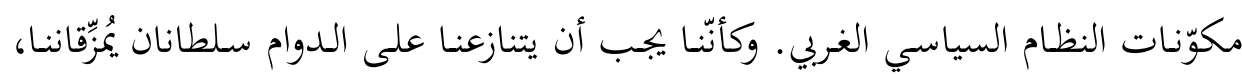

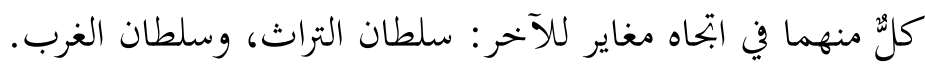

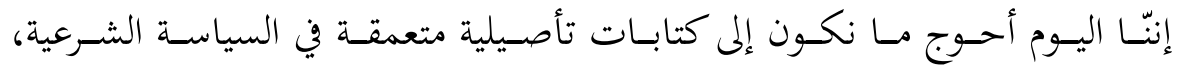

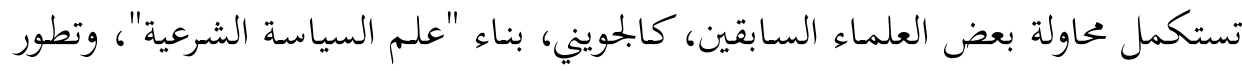

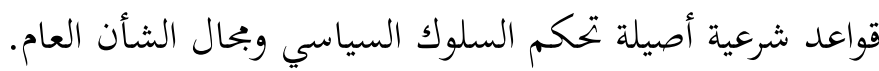

